MARCOS SOUSA CÉSAR

\title{
INTERPRETAÇÃO DE CICLOS IMOBILIÁRIOS EM EDIFÍCIOS COMERCIAIS DE PADRÃO CORPORATIVO. APLICAÇÃO NA CIDADE DE SÃO PAULO DURANTE O PERÍODO DE 1994 A 2004
}

\author{
Dissertação apresentada à Universidade \\ de São Paulo para a obtenção do Título \\ de Mestre em Engenharia.
}

São Paulo 


\title{
INTERPRETAÇÃO DE CICLOS IMOBILIÁRIOS EM EDIFÍCIOS COMERCIAIS DE PADRÃO CORPORATIVO. APLICAÇÃO NA CIDADE DE SÃO PAULO DURANTE O PERÍODO DE 1994 A 2004
}

\author{
Dissertação apresentada à \\ Universidade de São Paulo para a \\ obtenção do Título de Mestre em \\ Engenharia \\ Área de Concentração: \\ Gerenciamento de Empresas e \\ Empreendimentos na Construção \\ Civil \\ Orientador: \\ Prof. Doutor \\ João da Rocha Lima Jr.
}

São Paulo

2007 
Este exemplar foi revisado e alterado em relação à versão original, sob responsabilidade única do autor e com a anuência de seu orientador.

São Paulo, de agosto de 2007.

Assinatura do autor

Assinatura do orientador

FICHA CATALOGRÁFICA

César, Marcos Sousa

Interpretação de ciclos imobiliários em edifícios comerciais de padrão corporativo. Aplicação na cidade de São Paulo durante o período de 1994 a 2004 / M.S. César. -- ed.rev. -- São Paulo, 2007.

p.

Dissertação (Mestrado) - Escola Politécnica da Universidade de São Paulo. Departamento de Engenharia de Construção Civil.

1.Mercado imobiliário - São Paulo (SP) 2.Escritórios - São Paulo (SP) 3.Indicadores econômicos I.Universidade de São Paulo. Escola Politécnica. Departamento de Engenharia de Construção Civil Il.t. 


\section{RESUMO}

Durante as últimas décadas, a concepção dos edifícios comerciais tem migrado de uma simples estrutura de suporte para se traduzir no ambiente necessário à realização de negócios, bem como parte integrante destes.

Portanto, o processo de planejamento de um novo empreendimento de escritórios deve envolver não somente as necessidades do usuário final, mas também deve considerar o momento político-econômico e do mercado em particular.

Variáveis econômicas, fatores provenientes da relação entre oferta e demanda dentro do mercado de escritórios e causas específicas e aleatórias das principais regiões de uma determinada área em estudo são significativos responsáveis pelo comportamento e aceitação pelo mercado de novos empreendimentos, formando, conseqüentemente, produtos imobiliários com determinada velocidade de absorção pelo mercado, caracterizando, por sua vez, o desempenho de empreendimentos.

Através de séries históricas do mercado de escritórios da cidade de São Paulo e de acontecimentos e indicadores políticos-econômicos, esta pesquisa objetiva inferir relações de causa e efeito entre ambos. 


\begin{abstract}
During the last decades, the commercial buildings have changed from a simple support structure to the necessary environment to influence business' results.

Therefore, the planning process for creating a new real estate (R.E.) development involves analyzing not only the tenant's requirements, but the economy and R.E. market scenario as well.

Economic variables, factors originated from offer and demand relations within real estate market, along with both specific and random causes in a distinct study region are meaningful determinants for new buildings' acceptance by the market. These reasons influence the demand absorption, contributing to characterize the developments' performance.
\end{abstract}

This research attempts to infer "cause and effect" relations between economy and R.E market through historical series of office market data in São Paulo, politicoeconomical indicators and events. 


\section{SUMÁRIO}

\section{LISTA DE TABELAS}

\section{LISTA DE FIGURAS}

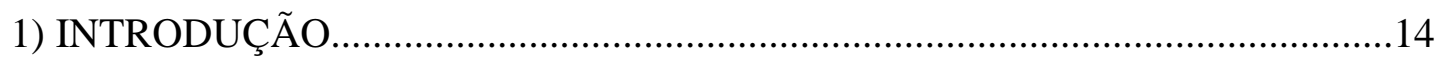

2) ECONOMIA E O MERCADO DE ESCRITÓRIOS...............................................32

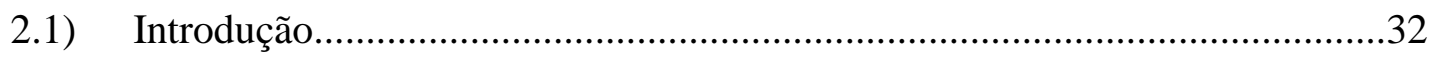

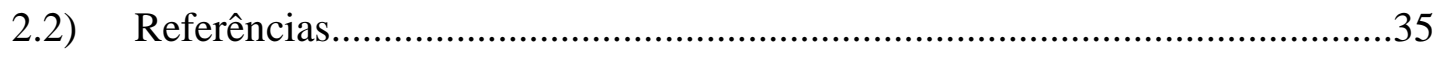

2.2.1) A globalização econômica e a decisão de investimento no Brasil.....................35

2.2.2) Investimentos de baixa flexibilidade em ambiente de incerteza no mercado de empreendimentos de escritórios dos estados unidos...................................................40

2.3) Principais acontecimentos econômicos do ciclo em estudo, que possivelmente influenciaram no mercado de real estate de São Paulo.

3) COMPORTAMENTO DOS INDICADORES ECONÔMICOS DURANTE O

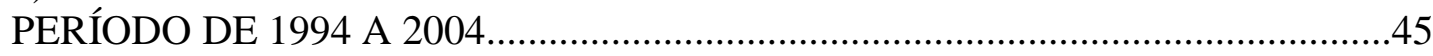

a) Produto Interno Bruto (PIB) brasileiro................................................................46

b) Investimentos Diretos Estrangeiros.................................................................48

c) as Taxas de Juros do Overnight/ SELIC..............................................................50

d) Variação anual do Índice de Lucratividade da Bolsa de Valores de São Paulo (IBOVESPA).................................................................................................53

e) IGP-DI (Índice Geral de Preços - Disponibilidade Interna), representando os

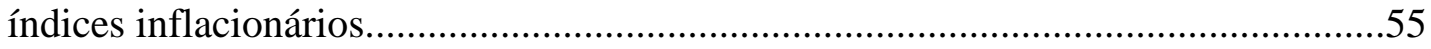

f) a balança comercial brasileira, para representar o comportamento das exportações

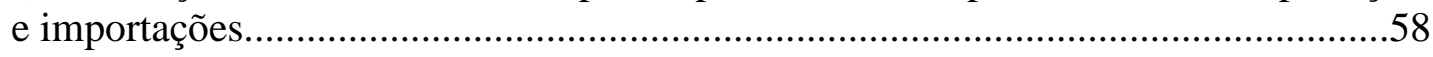

g) a variação cambial do Real (R\$) frente ao Dólar comercial americano (U\$)........62

4) DINÂMICA DE DESENVOLVIMENTO DO MERCADO DE ESCRITÓRIOS

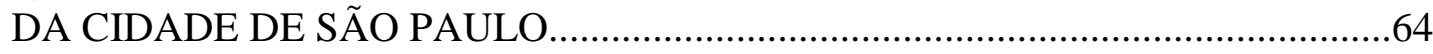

5) DESCRIÇÃO DOS INDICADORES DE REAL ESTATE DURANTE O PERÍODO DE 1994 A 2004 NA CIDADE DE SP....................................................71

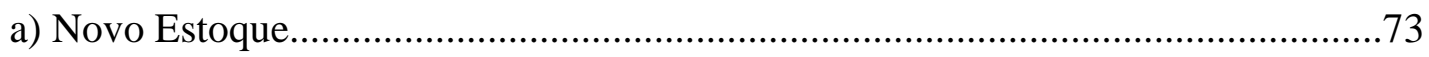


b) Absorção Bruta de Primeira e Segunda Mão...........................................................74

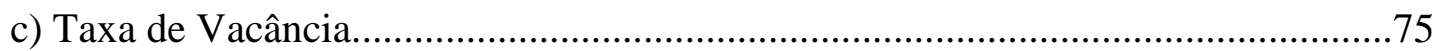

6) RELAÇÃO ENTRE O MERCADO DE ESCRITÓRIOS DE SÃO PAULO E A ECONOMIA BRASILEIRA ENTRE 1994 E 2004…………………………........77

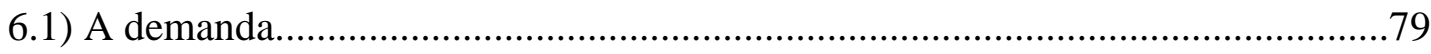

6.1.1) PIB brasileiro e investimentos diretos estrangeiros..........................................87

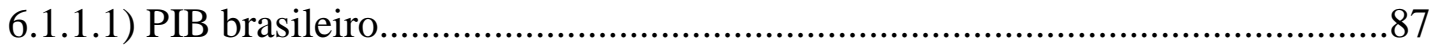

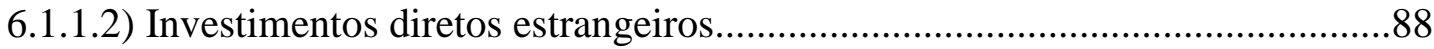

6.1.1.3) Conclusão (PIB brasileiro e investimentos diretos estrangeiros)...................91

6.1.2) Variação cambial do dólar frente ao real............................................................93

6.1.3) Comportamento da balança comercial brasileira...............................................96

6.1.4) Taxa de Juros SELIC...................................................................................100

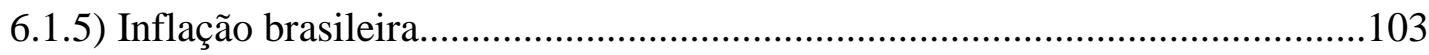

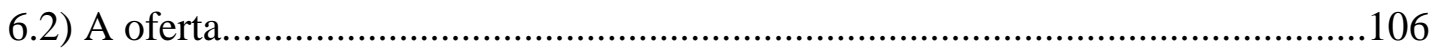

6.2.1) O Novo Estoque e o Produto Interno Bruto (PIB) brasileiro...........................114

6.2.2) O Novo Estoque e a Taxa de Vacância em edifícios de escritórios na cidade de

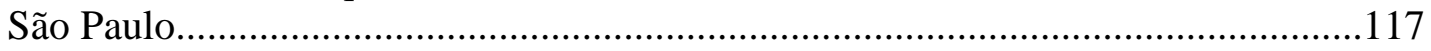

6.2.3) O Novo Estoque em edifícios de escritórios na cidade de São Paulo e a Variação anual do IBOVESPA..............................................................................121

7) CONCLUSÕES

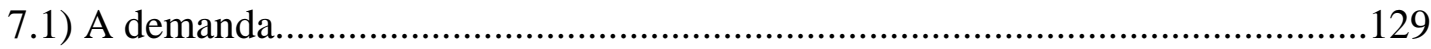

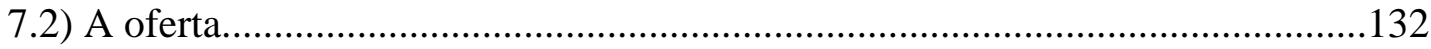

7.3) Sistematizações ou generalizações para futuras pesquisas e potenciais

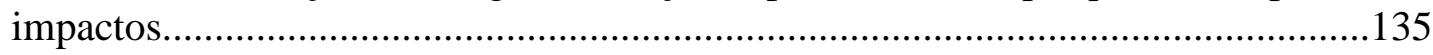

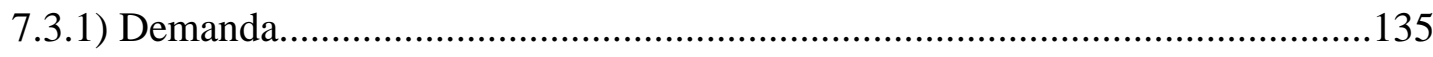

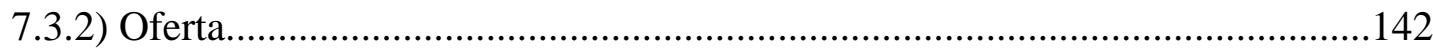

7.4) Comentários finais..........................................................................................146 
REFERÊNCIAS BIBLIOGRÁFICAS E BIBLIOGRAFIA RELACIONADA .......147

ANEXO 1: Roteiro de questionamentos de cada entrevista realizada com os agentes

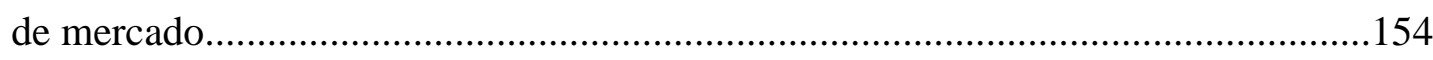




\section{LISTA DE FIGURAS}

Figura 1: Representação hipotética de um ciclo do mercado imobiliário de escritório e industrial. 15

Figura 2: Representação gráfica de um ciclo imobiliário hipotético. .18

Figura 3: Sistema de cerificação da qualidade de edifícios de escritórios no Brasil..28

Figura 4: Esquematização da influência entre a economia globalizada e a brasileira. .36

Figura 5: Explanação do cenário de expectativas e incertezas.. .38

Figura 6: Série histórica do PIB e da sua variação anual no ciclo em análise. .46

Figura 7: Série histórica do investimento direto estrangeiro no Brasil no ciclo em análise. .48

Figura 8: Série histórica do investimento direto estrangeiro no Brasil no período entre 1996 e 2002 incluindo e excluindo o montante relativo às privatizações.

Figura 9: Série histórica da taxa de juros referencial da economia brasileira (SELIC) no ciclo em análise .52

Figura 10: Série histórica da variação anual do IBOVESPA no ciclo em análise......53

Figura 11: Série histórica do IGPDI no ciclo em análise .56

Figura 12: Série histórica da balança comercial brasileira no ciclo em análise 60 
Figura 13: Série histórica da cotação do Dólar comercial americano no ciclo em análise.

Figura 14: Mapa esquemático da cidade de São Paulo destacando suas principais regiões de escritórios .64

Figura 15: Série histórica do novo estoque no ciclo em análise. .73

Figura 16: Série histórica do índice de absorção de espaços de escritórios no ciclo em análise. 74

Figura 17: Série histórica da taxa de vacância em espaços de escritórios no ciclo em análise. .75

Figura 18: Índice de absorção e sua variação anual. 79

Figura 19: Produto interno bruto brasileiro e demanda do mercado de escritórios de São Paulo, medida pela absorção de espaços vagos. .87

Figura 20 - investimentos diretos estrangeiros e demanda do mercado de escritórios de São Paulo, medida pela absorção de espaços vagos. .89

Figura 21: Relação entre a variação cambial (Dólar frente ao Real) e a absorção de espaços de escritórios. .94

Figura 22: comportamento da balança comercial brasileira x a absorção de espaços de escritórios em São Paulo. .96

Figura 23: exportação brasileira x variação cambial (Dólar frente ao Real) x absorção de espaços de escritórios. .97 
Figura 24: taxa de juros SELIC x índice de absorção de espaços de escritórios na

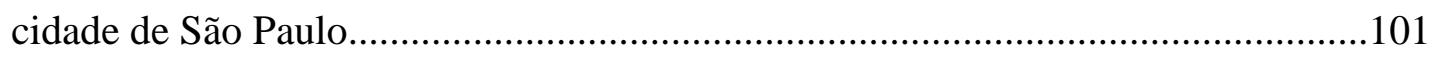

Figura 25: Variação do índice inflacionário IGP-DI x Absorção de espaços de

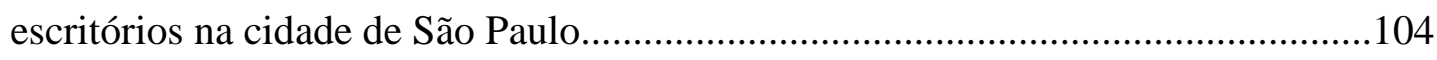

Figura 26: Representa o novo estoque contabilizado em áreas.............................108

Figura 26: Novo estoque com período de maturação de 2 anos e variação anual do

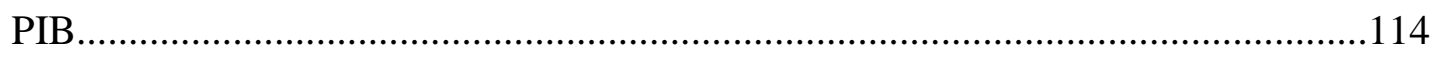

Figura 28: Novo estoque com período de maturação de 3 anos e variação anual do PIB.. 115

Figura 29: Taxa de vacância e novo estoque de espaços de escritórios em São Paulo

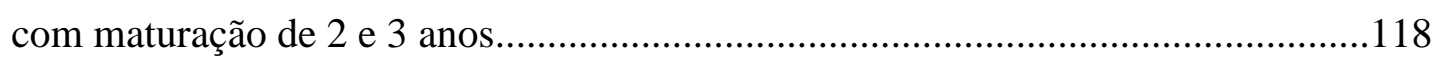

Figura 30 IBOVESPA e novo estoque de espaços de escritórios em São Paulo....121 


\section{LISTA DE TABELAS}

Tabela 1 - Explicação do comportamento teórico de mercado encontrado na figura

Tabela 2 - representa o investimento estrangeiro direto relativo a privatizações de 1996 a 2002

\section{ANEXO}

ANEXO - Roteiros de questionamentos de entrevistas realizadas com os agentes de mercado 


\section{LISTA DE ABREVIATURAS E SIGLAS}

EEL edifícios de escritório para locação;

PWC PricewaterhouseCoopers

NRE Núcleo de Real Estate da Escola Politécnica da USP

IPUB investimentos em setor público

ITRAD investimento no setor privado tradicional

IMOD investimento no setor privado moderno

PIB Produto Interno Bruto

SELIC Taxa de juros referencial brasileira

IBOVESPA Índice da Bolsa de Valores de São Paulo

IGP-DI Índice geral de preços

ACC Ar condicionado central

RMSP Região metropolitana de São Paulo

FMI Fundo monetário Internacional

FHC Fernando Henrique Cardoso

CEPAC Certificado de Potencial Adicional de Construção 


\section{1) INTRODUÇÃO}

Os empreendimentos comerciais com o objetivo de abrigar escritórios constituem um segmento representativo do mercado imobiliário no Brasil e no mundo.

Veronezzi (2004) menciona que a importância deste setor apresenta-se fundamentada pela sua finalidade, uma vez que os edifícios de escritórios são responsáveis por abrigar as atividades administrativas, financeiras, comerciais, de marketing e serviços.

A reestruturação da economia global dos últimos trinta anos demonstrou uma concentração das atividades terciárias nas regiões urbanas do mundo, gerando demanda por empreendimentos de escritórios direcionados a atender as necessidades destas atividades. Desta forma, recursos humanos qualificados, novas formas de cooperação produtiva e empresarial, serviços financeiros e gerenciais integrados, comércio varejista e entretenimento passaram a estar concentrados em pólos localizados em regiões urbanas do mundo.

Apareceram os centros de negócios, os quais concentram empreendimentos de escritórios, comércio e, em menor freqüência, estruturas adjacentes às principais como, por exemplo, centro de convenções, hotéis e shopping centers.

Ainda segundo Veronezzi (2004), o antigo ponto de vista do edifício de escritórios como sendo somente a estrutura física de suporte foi substituída pelo ponto de vista de que os empreendimentos de escritórios são não somente o ambiente adequado ao desenvolvimento dos negócios, mas também parte integrante dos mesmos. 
O processo de formatação de um empreendimento de base imobiliária, neste caso um edifício comercial para locação, entre outros aspectos, deve analisar além das necessidades do consumidor final (ocupantes do edifício) e dos indicadores do mercado imobiliário, indicadores econômicos, uma vez que, segundo Rocha Lima e Alencar (2004), "numa perspectiva internacional, os mercados de real estate mais dinâmicos e, particularmente os edifícios de escritório para locação (EEL), se desenvolveram nas economias mais sofisticadas e de maior dimensão, de tal sorte que se percebe de modo até intuitivo uma vinculação do comportamento nos mercados de EEL com a própria performance macroeconômica nos países mais desenvolvidos."

Assim como outros mercados e a economia como um todo, o mercado de EEL apresenta comportamento cíclico e seus participantes, em mercados maduros, monitoram as fases nas quais cada segmento de mercado se encontra, como no exemplo do relatório periódico European Property Cycle Monitor realizado pelo setor de Real Estate do Deutsche Bank Group.

Figura 1 - representação hipotética de um ciclo do mercado imobiliário de escritório e industrial.

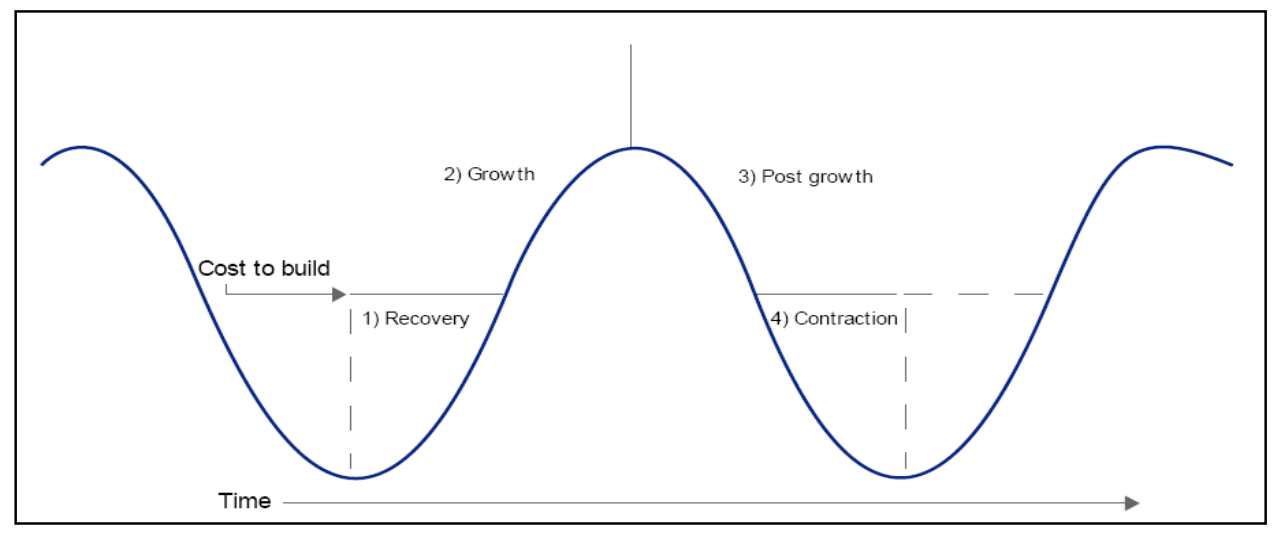

Fonte: Periódico do Deutsche Bank Group publicado em dezembro de 2006 
Este relatório tem fundamento na visão de que o mercado flutua segundo o ciclo gerado pelas expectativas dos seus agentes, motivadas por oscilações entre oferta e demanda no setor.

O Deutsche Bank Group apresenta o ciclo de valores dos edifícios no mercado de escritórios e industrial dividido em quatro fases de características distintas, onde o indicador taxa de vacância e os valores de locação apresentam-se em situações inversas:

(i) a primeira fase apresentada foi denominada como Recovery (recuperação), uma vez que constitui um momento de taxa de vacância ${ }^{1}$ alta, mas em processo de declínio. Desta forma, os respectivos valores de locação atingiram seus limites inferiores, passaram pelo ponto de inflexão da curva e se encontram em processo de ascensão;

(ii) após o período de recuperação, o relatório apresenta uma nova fase denominada Growth (crescimento). Esta se caracteriza por apresentar taxa de vacância baixa e ainda em processo de declínio, porém reduzindo a intensidade de redução deste indicador até atingir um novo ponto de inflexão da curva. Vale comentar que, nesta fase, os valores de locação apresentam-se em processo de ascensão, porém reduzindo a intensidade do crescimento até atingir a estabilidade no início da próxima fase;

(iii) Após o ponto de inflexão comentado no item anterior, o ciclo se encontra em um momento denominado Post Growth (pós-crescimento). A taxa de vacância encontra-

\footnotetext{
${ }^{1}$ Taxa de vacância representa a relação percentual entre o total dos espaços vagos e o estoque total, sendo este caracterizado pela somatória entre os espaços vagos e os ocupados.
} 
se baixa, porém em processo de ascensão. Enquanto os valores de locação estão iniciando um processo de ascensão;

(iv) Por último, o relatório menciona a fase Contraction (contração), a qual apresenta taxa de vacância alta e em processo de ascensão, mas já reduzindo a intensidade do crescimento. Por outro lado, os valores de locação apresentam-se em processo de declínio.

Assim como o banco alemão foi citado, pode-se mencionar como um segundo exemplo a PricewaterhouseCoopers (PWC), a qual apresentou em seus periódicos um modelo de representação do ciclo imobiliário demonstrando a tendência de comportamento de indicadores e de expectativas de agentes do mercado:

O periódico divide o ciclo em quatro fases denominadas recession (recessão), recovery (recuperação), expansion (expansão) e contraction, (contração), conforme apresentado na Tabela 1.

(i) O modelo caracteriza a fase de recessão com um crescimento desacelerado da taxa de vacância e de redução de valores de aluguel, onde a oferta e a demanda se apresentam em declínio e a renda do capital investido ${ }^{2}$ se apresenta em ascensão, gerando um desinteresse dos investidores pelo setor e uma conseqüente ausência de transações.

(ii) A fase de recuperação é caracterizada por um início de aumento da demanda e estabilidade da oferta, que leva (i) a taxa de vacância a um ponto de inflexão e (ii) os valores de locação e a taxa de capital a uma estabilidade. Esta fase ainda apresenta

\footnotetext{
${ }^{2} \mathrm{O}$ periódico apresenta a renda do capital investido (Cap Rate) representando a relação entre valor do capital investido e o valor da renda do investimento em um determinado imóvel.
} 
poucos investidores interessados, uma vez que, embora as receitas já se encontrem em ascensão, as taxas de capital ainda apresentam-se expressivas.

\section{Figura 2 - Representação gráfica de um ciclo imobiliário hipotético}

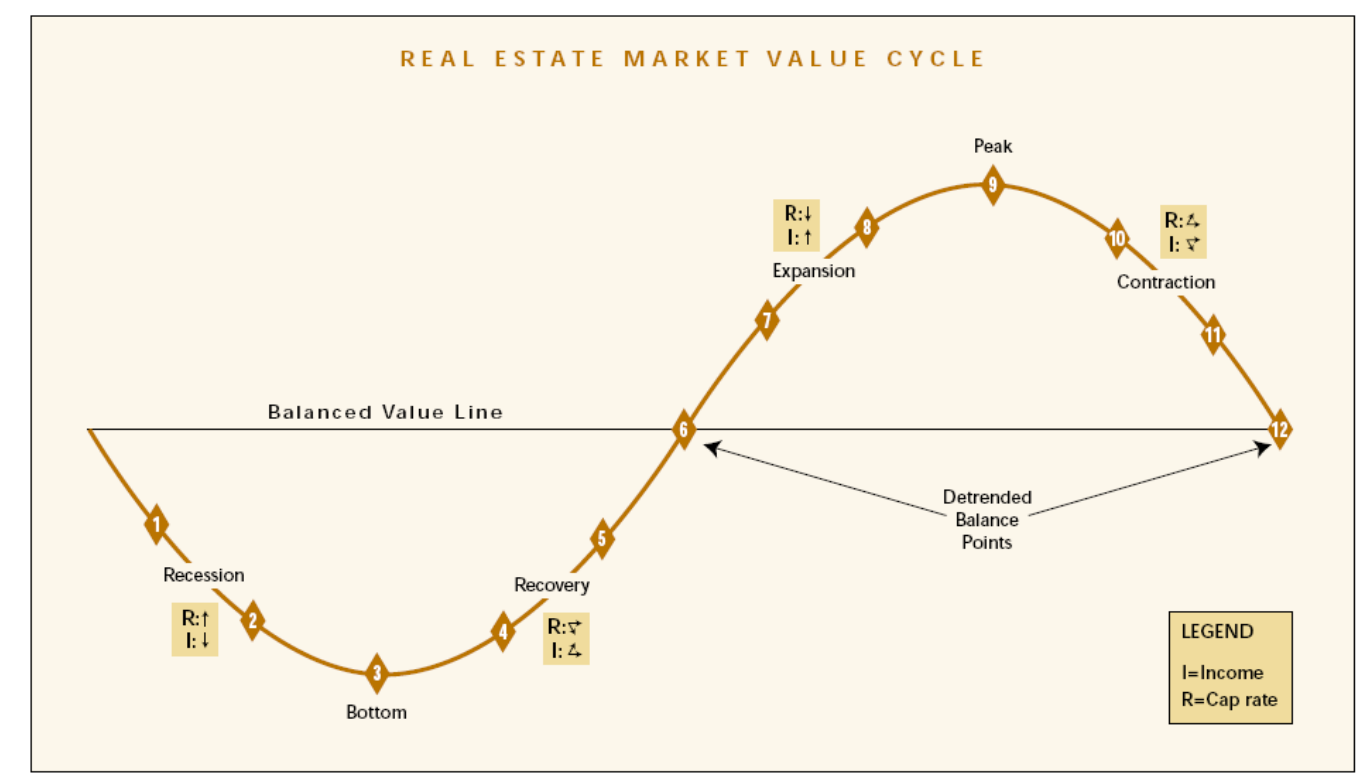

Fonte: Periódico da PricewaterhouseCoopers (PWC)

(iii) A fase de expansão é apresentada com o início de aumento da oferta e com um forte crescimento na demanda, que leva a declínios na taxa de vacância e aumento nos valores de locação. Este momento de mercado motiva o interesse dos investidores, uma vez que apresentam aumentos significativos nas receitas, bem como o início de declínio nas taxas de capital.

(iv) A última fase é denominada contração e se caracteriza por um aumento da oferta superior ao da demanda, a qual já se encontra em um momento de desaceleração do crescimento. Desta forma, os valores de locação também apresentam um crescimento desacelerado. Segundo o periódico, embora este momento demonstre receitas estáveis (ou declinando) e redução no fluxo de capitais, esta fase ainda apresenta um número expressivo de investidores interessados. 
Tabela 1: Explicação do comportamento hipotético de mercado encontrado na figura

\begin{tabular}{|c|c|c|c|c|}
\hline Indicadores & Recession & Recovery & Expansion & Contraction \\
\hline Oferta & Declinando & Ponto Inferior & Início de aumento & $\begin{array}{c}\text { Aumentando mais } \\
\text { que a demanda }\end{array}$ \\
\hline Demanda & Declinando & $\begin{array}{l}\text { Início de } \\
\text { recuperação }\end{array}$ & $\begin{array}{c}\text { Forte, maior que o } \\
\text { novo estoque } \\
\text { entregue }\end{array}$ & $\begin{array}{l}\text { Crescimento } \\
\text { positivo, porém } \\
\text { desacelerando }\end{array}$ \\
\hline Vacância & Aumentando & $\begin{array}{c}\text { Declinando até o } \\
\text { ponto de } \\
\text { balanceamento }\end{array}$ & Declinando & $\begin{array}{c}\text { Aumentando até o } \\
\text { ponto de } \\
\text { balanceamento }\end{array}$ \\
\hline Valor de Aluguéis & Declinando & Sem Aumentos & Aumentando & $\begin{array}{l}\text { Crescimento } \\
\text { positivo, porém } \\
\text { desacelerando }\end{array}$ \\
\hline Cap Rate (*) & Aumentando & $\begin{array}{c}\text { Estável em altas } \\
\text { taxas }\end{array}$ & Início de declínio & $\begin{array}{c}\text { Declinando assim } \\
\text { como o fluxo de } \\
\text { capitais }\end{array}$ \\
\hline Investidores & $\begin{array}{l}\text { Ausência de } \\
\text { transações }\end{array}$ & $\begin{array}{c}\text { Poucos } \\
\text { interessados }\end{array}$ & Interessados & Interessados \\
\hline $\begin{array}{r}\text { Impacto nos } \\
\text { Valores }\end{array}$ & $\begin{array}{c}\text { Receitas } \\
\text { declinando com } \\
\text { aumento da taxa } \\
\text { de capital }\end{array}$ & $\begin{array}{c}\text { Receitas } \\
\text { aumentando com } \\
\text { altas taxas de } \\
\text { capital }\end{array}$ & $\begin{array}{c}\text { Receitas } \\
\text { aumentando com } \\
\text { declínio das taxas } \\
\text { de capital }\end{array}$ & $\begin{array}{c}\text { Receitas estáveis } \\
\text { ou declinando } \\
\text { com a } \\
\text { estabilidade ou } \\
\text { aumento das } \\
\text { taxas de capitais } \\
\end{array}$ \\
\hline
\end{tabular}

(*) O periódico apresenta Cap Rate representando a relação entre valor do capital investido e o valor da renda do investimento em um determinado imóvel.

Fonte: Periódico da PWC

Ambos os exemplos de modelos apresentados pelo Deutsche Bank Group e pelo

PWC constituem-se em representações hipotéticas, uma vez que existem diversos

fatores que impactam sobre a amplitude, freqüência e imperfeições de tais oscilações.

Diversos autores abordaram o assunto, observando e analisando o comportamento de determinados mercados de real estate, bem como o impacto da economia nos mesmos.

De acordo com Mueller (2002), os ciclos de real estate foram primeiramente discutidos por Homer Hoyt em 1933 na análise do mercado de Chicago. Após tal estudo, diversos outros mercados receberam atenção dos pesquisadores no decorrer dos anos.

Pritchett (1984) descreveu a teoria de que existem ciclos nacionais de mercado de real estate, entretanto tais oscilações se diferenciam quando analisados do ponto de vista do perfil de imóvel. Ele menciona também que o crescimento e declínio da 
oferta sempre possuem um atraso (lag) em relação ao crescimento e declínio da demanda. Desta forma, afirma que os picos de alta e de baixa da oferta e da demanda ocorre quando estes estão se movendo em direções opostas.

Entendendo e aceitando como premissa o diferente comportamento de mercado de diferentes perfis de imóveis (escritório, industria, lojas, residencial entre outros) a presente dissertação concentrará seus estudos em edifícios de escritórios.

O atraso mencionado por Pritchett (1984) da oferta em relação à demanda se deve principalmente a dois componentes: (i) a relação entre oferta e demanda se configura em causa e efeito, ou seja, após o investidor perceber com segurança um aumento da demanda, toma a decisão de investir e (ii) um edifício leva um certo período para ser construído e, portanto, para ser contabilizado como oferta entregue no mercado.

Witten (1997) menciona que cada cidade tem seu próprio ciclo de mercado imobiliário, o qual é único em amplitude e frequiência e são dependentes da dinâmica interna de cada mercado. Ele também afirma que o novo estoque (novas propriedades entregues ao mercado) é mais volátil que a demanda, uma vez que a oferta é freqüentemente determinada pela disponibilidade de estruturas de financiamento ao invés de ser definido pela necessidade do mercado. Outra de suas observações, que se configura relevante, é o fato das variações de novo estoque deste mercado raramente se moverem tão suavemente como as clássicas curvas de tendências esboçadas nos gráficos hipotéticos, mas sim por saltos causados pela hesitação dos investidores ou espera por claros sinais de mudanças no mercado.

A maior volatilidade do novo estoque em relação à demanda apresenta-se como importante assunto a ser analisado por se demonstrar um dos geradores de excesso de 
oferta no mercado. Rocha Lima, em aula, justifica parte da causa de tal volatilidade no "inconsciente coletivo" dos investidores e incorporadores, ou seja: a falta de informações de diversos agentes de um mesmo setor faz com que diversos agentes tomem iniciativa para investir baseados no sucesso de empreendimentos já existentes, ao invés de se basearem em estudos de comportamento do mercado futuro.

Brown (1984) defendeu o modelo do ciclo como uma simplificação das complexidades da realidade. Acreditava que as séries temporais deveriam ser usadas para determinar a extensão e a amplitude dos ciclos, assim como medir o seu movimento com o tempo. Segundo ele, uma chave para este tipo de pesquisa é a identificação e remoção dos componentes sazonais e tendenciosos inerentes nas séries. Ele conclui que o sucesso dos analistas, consultores, investidores e proprietários está em dar maior credibilidade às análises do ciclo do mercado imobiliário. Brown informa que havia em sua época falta de um método uniforme de medição do desenvolvimento do mercado, que dificultava a conclusão sobre amplitude e extensão dos ciclos.

Vale comentar que tal deficiência na uniformidade das medições que Brown demonstrou existir há mais de vinte anos em países desenvolvidos ainda se demonstra presente no Brasil, dificultando a possibilidade de, com o intuito de obter maior precisão das análises, cruzar informações de diferentes fontes de pesquisa.

Wheaton (1987), através de uma amostra de dez cidades, estimou um ciclo de mercado nacional para os Estados Unidos por doze anos. Ele percebeu que cada cidade tinha o seu ponto de "pico e de vale" de acordo com o seu próprio ciclo, que 
era com uma margem de até dois anos da média das dez cidades. Ele estudou as causas que tornam os ciclos de mercado aproximadamente cíclicos e foi notório pelo seu modelo que uma variação na taxa de emprego impõe expressivo impacto no comportamento do ciclo (oferta reage com atraso em relação à demanda).

Pyhrr, Born e Web (1990), compararam típicos modelos de tendências para real estate com a teoria do modelo cíclico baseada na demanda, oferta e inflação. Eles concluíram que o momento de aquisição e de disposição no ciclo pode ser bastante importante para a taxa de retorno recebida dos investimentos de real estate.

Pyhrr, Born, Robinson e Lucas (1996), compararam tradicionais métodos de avaliação com modelos usando premissas do ciclo (demanda, oferta, absorção, valores praticados em propriedades existentes e em construção). Eles concluíram que avaliações com premissas do ciclo podem melhorar significantemente as conclusões. Desta forma, um modelo cíclico pode ser um melhor indicador do valor de investimento (longo prazo), enquanto a simples definição do valor de mercado (momento singular) resulta em conclusões de qualidade inferior.

Mueller e Laposa (1994, 1995), discutiram a diferença entre o ciclo no mercado geral e nos submercados. Esta pesquisa menciona que os ciclos dos submercados podem mover-se diferentemente do ciclo do mercado geral no curto prazo, mas tipicamente as tendências dos submercados seguem as do mercado geral no longo prazo.

Mueller (1995), estratificou o ciclo de mercado imobiliário em dois tipos distintos de ciclo: (i) ciclo físico, que consiste em oferta, demanda e ocupação de espaços físicos em um mercado local que afeta o comportamento do valor de locação; (ii) ciclo financeiro, que aborda o fluxo de capital no mercado imobiliário para imóveis 
existentes e em construção, que afetam os preços das propriedades. Esta separação entre físico e financeiro auxilia a compreensão do atraso (lag) entre a ocupação do mercado versos os preços praticados.

Grenadier (1995) desenvolveu um modelo de preços teórico de como a taxa de vacância e a taxa de locação interage. Ele assumiu como hipótese que há uma considerável inércia dos proprietários de edifícios existentes ajustarem aluguéis e níveis de ocupação em resposta a alterações no ambiente econômico. Ele se preocupa em enfatizar o fato da ocorrência frequente de excesso de oferta no mercado ( overbuilding $^{3}$ ) durante períodos de baixa ocupação, através da proposta de fazer o possível para firmar uma nova locação com o intuito de manter a taxa de vacância em patamares aceitáveis, uma vez que os proprietários sofrem uma tendência de manter altos valores de locação antes de alugar o espaço e também que longos períodos de construção casados ao fato de uma construção em andamento não ser reversível podem causar expressivo excesso de oferta. Adicionalmente ele menciona a volatilidade da demanda e conclui que mercados com maior volatilidade de demanda apresenta maior probabilidade de overbuilding.

Segundo Rocha Lima e Alencar (2004), "a literatura especializada publicou na última década uma série de trabalhos, desenvolvidos principalmente a partir do comportamento nos mercados americanos, no Reino Unido e em algumas cidades do sudeste asiático, que corroboraram a correlação existente entre a performance no setor de edifícios para locação e a taxa de expansão do produto interno bruto (PIB) nesses países".

\footnotetext{
${ }^{3} \mathrm{O}$ uso da palavra overbuilding justifica-se por expressar claramente o excesso de oferta de edifícios de escritórios não correspondido pela respectiva demanda.
} 
"Nestas economias fortemente fundadas e reguladas através de mecanismos de mercado, a preocupação com a produção e a disponibilização de informações de comportamento setorial é bastante maior do que a que vigora nos mercados brasileiros, a ponto de ser possível tratar informações de mercado com um grau de sofisticação que permite a validação de modelos explicativos, ou de previsão, também bastante mais evoluídos do que seria factível validar no Brasil”.

Rocha Lima e Alencar (2004) ainda acrescentam que, "de acordo com o estágio da economia, é possível admitir que os coeficientes de correlação entre expansão macroeconômica e performance no setor de EEL podem flutuar se a estrutura econômica estiver baseada em atividades que demandem menos áreas de escritórios. Do mesmo modo, o padrão histórico da correlação do setor com a macroeconomia pode alterar-se ao longo do tempo em função da evolução tecnológica e gerencial na economia, o que pode resultar para mesmas taxas de crescimento do PIB, em períodos históricos distintos numa dada região urbana, solicitações ou absorções distintas de áreas de escritórios para locação".

Dessa forma, a análise do comportamento de variáveis do subsistema mercado de escritórios contra variáveis do sistema econômico constitui uma ferramenta interessante para os empreendedores na etapa de planejamento de novos empreendimentos, considerando o passado e o presente, além das expectativas do futuro, para o embasamento das decisões.

Vale ainda salientar que, por mais que avaliemos fatores teóricos geradores de pressões sobre comportamento do mercado imobiliário, existem componentes que dificultam qualquer dimensionamento, tais como alargamento de avenidas, mudanças 
de zoneamento, incentivos fiscais, atividades dos empreendedores em determinadas regiões da cidade, etc.

Adicionalmente, entendemos que fatores econômicos (mundiais e domésticos), efeitos provenientes da relação entre oferta e demanda dentro do mercado imobiliário, bem como causas específicas e aleatórias de determinados locais, são impactantes no sucesso ou insucesso dos empreendimentos de escritórios.

Com o intuito de aumentar a qualidade das conclusões, através de entrevistas realizadas em 2006, o capítulo seis $^{4}$ da presente pesquisa, juntamente com questionários específicos que se encontram em anexo, foi submetido à análise de especialistas $^{5}$ do mercado imobiliário da cidade de São Paulo apresentados a seguir.

(i) Adriano Sartori (Sartori), gerente sênior da divisão comercial da CB Richard Ellis (CBRE) especializada em aconselhamento a incorporadores e proprietários do mercado na fase formatação, elaboração e comercialização de novos empreendimentos comerciais corporativos;

(ii) Martin Jaco (Jaco) e Edson Ferrari (Ferrari), respectivamente diretor e gerente da divisão da empresa CBRE especializada em aconselhamento a investidores imobiliários, onde a expressiva maioria das transações gerenciadas por sua equipe

\footnotetext{
${ }^{4} \mathrm{O}$ capítulo seis da presente pesquisa constitui a manipulação dos dados apresentados nos capítulos anteriores e apresenta o cruzamento entre os indicadores imobiliários e econômicos, bem como a descrição dos acontecimentos político-econômicos do ciclo.

${ }^{5}$ Companhias especializadas no mercado imobiliário foram procuradas para, através de entrevistas, informar os respectivos entendimentos sobre o assunto, porém consideraram ser confidencial o nível de informação solicitada. Desta forma, as entrevistas foram concentradas em um professor de investimentos imobiliários da instituição de ensino FGV e quatro executivos da CBRE. Estes últimos, além de serem especialistas em distintas áreas do mercado em estudo, estão familiarizados com os dados, indicadores imobiliários e critérios de seleção da amostra utilizados na presente pesquisa.
} 
abrange edifícios de escritórios corporativos, os quais constituem o objeto da presente pesquisa.

(iii) Fernando Terra (Terra), gerente da divisão serviços corporativos globais da empresa CBRE, lidera uma equipe especializada em atender e aconselhar empresas ocupantes de espaços no Brasil e na América Latina, bem como gerenciar suas transações imobiliárias.

(iv) Mauro Miranda (Miranda), coordenador do programa de investimentos imobiliários do programa de educação continuada da FGV-Eaesp (Escola de Administração de Empresas de São Paulo, da Fundação Getulio Vargas), o qual, através de experiência em real estate nos mercados de São Paulo e de Nova Iorque, pôde contribuir com a presente pesquisa de forma significativa.

Desta forma, acompanhando o comportamento de gráficos de séries históricas compreendidas entre os anos de 1994 e 2004 e observando os principais acontecimentos econômicos ocorridos no período em estudo, esta dissertação visou analisar de forma crítica parâmetros que influenciam no comportamento dos ciclos de ocupação em edifícios de escritórios de padrão corporativo na cidade de São Paulo.

Durante a fase de definição do universo de edifícios a ser considerado na presente pesquisa, foi analisado o estudo realizado por Veronezzi (2004). Esta, percebendo a diversidade de classificações empregadas no mercado imobiliário para fazer referência à qualidade de edifícios de escritórios, motivou-se a elaborar um sistema mais completo e criterioso de certificação de edifícios de escritórios no Brasil, através de uma matriz de atributos e um comitê de classificação. Este sistema se 
configura responsável pela definição de classes ou categorias onde os edifícios de escritórios se encontram, representando a qualidade dos mesmos para o ocupante do espaço.

Em linhas gerais, de acordo com Veronezzi (2004), um empreendimento comercial para escritórios, quando enquadrado segundo o sistema de certificação por ela proposto, tem suas especificações e suas qualidades analisadas sob o ponto de vista do usuário final.

Desta forma, através de pontuações sobre uma matriz, a avaliação dos atributos de cada empreendimento analisado é expressa. O valor conclusivo desta pontuação é então enquadrado em uma pré-definida escala de classificação, a qual possibilita a hierarquização para o edifício entre as categorias AAA, AA, A, BBB, BB, B e C. Vale comentar que a inserção do prédio nesta classificação segundo uma classe é consolidada por um comitê de classificação e, então, o Núcleo de Real Estate (NRE) da Escola Politécnica da Universidade de São Paulo (EPUSP) emite um certificado de qualidade oferecido a todo o mercado nacional. 
Para tal, foi criada uma estrutura do sistema de classificação, segundo o seguinte fluxograma:

Figura 3: Sistema de cerificação da qualidade de edifícios de escritórios no Brasil

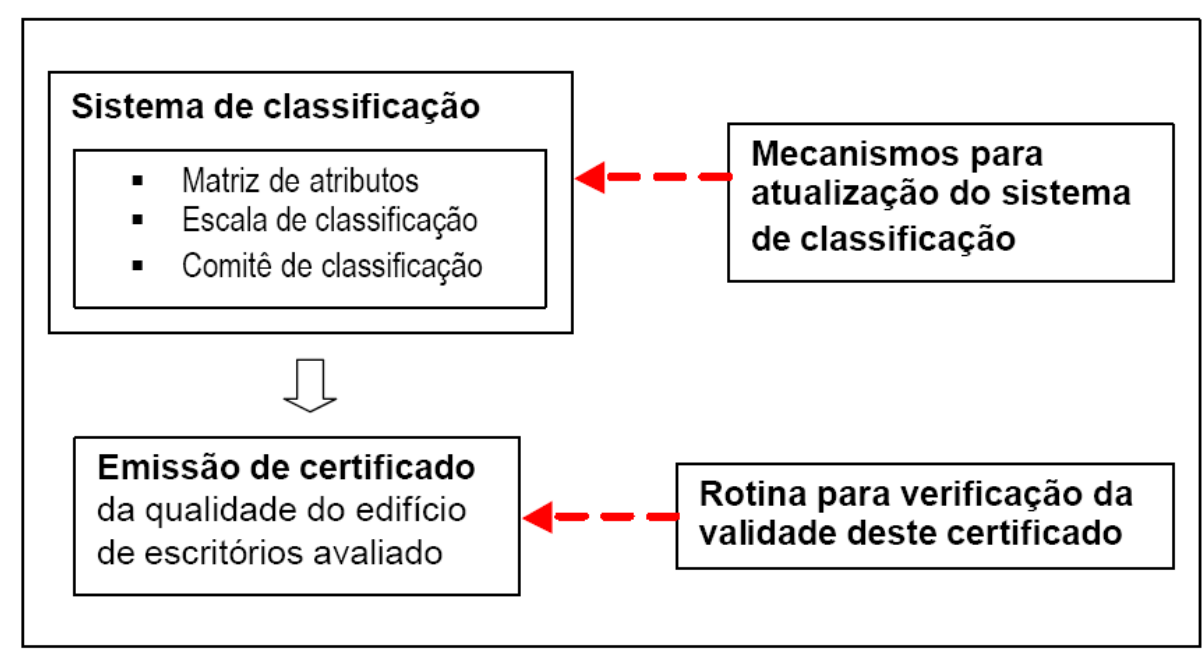

Fonte: Dissertação de Mestrado da Veronezzi (2004) pela Escola Politécnica de São Paulo

A fundamentação da elaboração do sistema de classificação supramencionado consistiu em, além de pesquisas bibliográficas, entrevistas com agentes de mercado ${ }^{6}$, visitas a edificações e observações realizadas no mercado do segmento em estudo, bem como em arbitragens iniciais, seguidas de testes de validação e calibragem com diversos ajustes.

É importante perceber que, embora este sistema de certificação possua componentes e fundamentos objetivos, ele reflete a opinião subjetiva da instituição emissora do certificado.

\footnotetext{
${ }^{6}$ Veronezzi (2004) define os agentes de mercado atuantes em sua pesquisa como PMBE, que significa "participante do mercado de edifícios brasileiros de escritórios".
} 
Em outras palavras, a colocação de um determinado empreendimento em uma determinada classe (de AAA até C) é realizada de forma pré-definida e objetiva (resultado da pontuação), porém a elaboração ${ }^{7}$ da matriz de atributos e o preenchimento $^{8}$ desta são subjetivos.

Embora ciente da amplitude do trabalho realizado por Veronezzi em 2004 pertencente à EPUSP, a presente pesquisa não considerará o seu critério de classificação de edifícios como base para determinação do seu universo de edifícios a serem estudados devido à dificuldade de operacionalização dos dados, uma vez que, para este estudo, será necessário o uso de um conceito integralmente objetivo de seleção dos edifícios a serem considerados no universo, bem como será preciso um histórico existente uniforme de indicadores do mercado imobiliário no ciclo de 1994 a 2004.

Desta forma, foram utilizados dados de séries históricas fornecidas pela empresa de consultoria imobiliária CBRE, os quais são uniformes para todo o período em estudo, bem como possibilitam o uso de fatores objetivos como critérios para seleção do universo de análise.

Com o objetivo de identificar um universo de análise representativo dos edifícios de escritórios com padrão corporativo na cidade de São Paulo, definimos os seguintes critérios:

\footnotetext{
${ }^{7}$ A estruturação desta matriz se deu a partir de uma arbitragem inicial com validação e calibragem.

${ }^{8}$ Embora existam critérios, o preenchimento da matriz necessita de um julgamento.
} 
a) edifícios de escritórios com lajes a partir de $250 \mathrm{~m}^{2}$ e área útil total acima de $1.000 \mathrm{~m}^{2}$, com o objetivo de excluir lojas e pequenos edifícios, onde operam consultórios médicos, dentistas ou pequenas empresas, por exemplo;

b) edifícios providos de sistema de ar-condicionado central (ACC), uma vez que, segundo entendimentos da empresa fornecedora do banco de dados, a presença de tal sistema consiste em um grande "divisor de águas" de patamar de qualidade dos edifícios de escritórios do mercado de São Paulo. Vale comentar que aproximadamente $50 \%$ da metragem total dos edifícios da cidade de São Paulo são providos de sistema de ACC.

c) Regiões incluídas no estudo: Paulista, Jardins e Marginal Pinheiros. Contido no universo das demais regiões, foi excluído da análise a região central, especialmente pela razão da não conformidade de seu estoque com os padrões de referência da amostra, e outras regiões como a Água Branca ou Barra Funda e a Vila Mariana, cuja oferta e demanda são pequenas o suficiente para não justificarem sua inclusão nas análises. 
Vale ressaltar a representatividade do montante de empreendimentos de padrão corporativo selecionados sobre o universo total dos edifícios de escritórios da cidade de São Paulo, uma vez que os mesmos concentram expressiva parcela dos investimentos no setor e, segundo informações da CBRE, os edifícios abordados nesta pesquisa abrangiam, em dezembro de $2004^{9}, 442$ edifícios, totalizando em metros quadrados, $69 \%$ de dos edifícios ${ }^{10}$ comerciais da cidade providos de sistema de ar condicionado central e $37 \%$ dos edifícios ${ }^{11}$ com e sem sistema de ar condicionado central.

\footnotetext{
${ }^{9}$ Dezembro de 2004 foi o momento final do ciclo em estudo.

${ }^{10}$ Edifícios com lajes a partir de $250 \mathrm{~m}^{2}$ e áreas úteis totais acima de $1.000 \mathrm{~m}^{2}$.

${ }^{11}$ Edifícios com lajes a partir de $250 \mathrm{~m}^{2}$ e áreas úteis totais acima de $1.000 \mathrm{~m}^{2}$.
} 


\section{2) ECONOMIA E O MERCADO DE ESCRITÓRIOS}

\section{1) INTRODUÇÃO}

O mercado de Empreendimentos de Escritórios para Locação (EEL) na cidade de São Paulo é um segmento do sistema econômico que se encontra sujeito às lógicas gerais da economia, além das particulares do segmento específico. A partir dessa compreensão, entendemos que o mercado de EEL na cidade de São Paulo pode ser estudado, primeiramente, utilizando-se como referências para análise as teorias gerais da economia e, posteriormente, analisando-se suas peculiaridades, tanto aquelas relacionadas ao mercado de escritórios para locação, quanto àquelas pertinentes ao Brasil e à cidade de São Paulo.

Assim, com relação às lógicas gerais da economia, serão explorados os aspectos das teorias econômicas que procuram explicar as decisões de investimento dos agentes econômicos em geral para entender as decisões daqueles que constroem e exploram os empreendimentos de escritórios para locação no ambiente brasileiro.

Para os aspectos gerais das teorias econômicas, utilizaremos como uma referência neste capítulo o trabalho de Fonseca Neto, "Globalização Financeira e Restrições ao Crescimento: a Economia Brasileira a partir da Década de Noventa", tese de doutorado defendida em 2004 na Universidade de Brasília. Este trabalho aborda os elementos da globalização econômica recente e seus impactos no desenvolvimento econômico brasileiro, percorrendo as teorias econômicas de diferentes "escolas", da neoclássica à pós-keynesiana, explorando suas convergências e contribuindo com suas próprias idéias. 
Quanto aos aspectos particulares do EEL, basearemos nossas reflexões neste capítulo inicialmente no artigo dos autores Sivitanidou e Sivitanides, "Does the Theory of Irreversible Investments Help Explain Movements in Office-Commercial Construction?", publicado no periódico "REAL ESTATE ECONOMICS” em 2000. Neste artigo, os autores utilizam como referencial a teoria econômica neoclássica, incorporando a questão da taxa de atratividade de investimentos irreversíveis em ambiente de incerteza, para analisar o mercado de EEL dos Estados Unidos.

Com relação aos aspectos particulares do EEL, em seguida, recorremos à contribuição dos Professores do NRE, da EPUSP, como exemplo o texto de Rocha Lima e Alencar, "O Mercado de Edifícios de Escritórios para Locação em São Paulo: Ciclos para Absorção do Estoque e para a Retomada da Atratividade do Investimento" de 2004, para além dos aspectos gerais, finalmente imergirmos nas questões brasileiras e paulistanas. Nesse texto, em sua primeira parte, encontramos reflexões sobre aspectos estruturais e econômicos de como ocorrem as decisões de investimento e, em sua segunda parte, uma análise do mercado de São Paulo entre 2000 e 2004, como também o estabelecimento de um possível cenário para os anos seguintes.

A escolha desses textos deve-se ao fato de apresentarem, em comum, reflexões sobre as decisões de investimento dos agentes econômicos em ambiente de incerteza. $\mathrm{O}$ primeiro deles é mais abrangente, tanto do ponto de vista das diferentes vertentes teóricas da economia, como também por tratar dos investimentos em geral segmentados em investimentos públicos, privados tradicionais e privados modernos. 
O texto da "REAL ESTATE ECONOMICS" também aborda os investimentos em ambiente de incerteza, todavia, diferentemente do anterior, com referências nos paradigmas da teoria neoclássica, focando nos investimentos em EEL do mercado das regiões metropolitanas dos Estados Unidos.

O texto da Escola Politécnica agrega a abordagem estrutural aos aspectos econômicos da decisão de investimento, focando em EEL do mercado de São Paulo.

Por fim, serão descritos acontecimentos econômicos que possivelmente exerceram ou ainda exercem impacto sobre o mercado de escritórios da cidade de São Paulo. 


\section{2) REFERÊNCIAS}

\subsection{1) A GLOBALIZAÇÃo ECONÔMICA E A DECISÃO DE INVESTIMENTO NO BRASIL}

Fonseca Neto (2004) parte da constatação de que o processo de globalização da economia brasileira, a partir dos anos noventa, no que diz respeito às decisões de investimento, atribuiu importância à demanda externa, às taxas de câmbio e aos custos de oportunidade mundiais, como também às volatilidades financeiras e cambiais.

Este autor divide os investimentos em setor público $\left(\mathrm{I}_{\mathrm{PUB}}\right)$, setor privado tradicional ( $\left.\mathrm{I}_{\mathrm{TRAD}}\right)$ e setor privado moderno $\left(\mathrm{I}_{\mathrm{MOD}}\right)$ com o objetivo de destacar que há investimentos mais expostos ao processo da globalização do que outros. Assim, o $\mathrm{I}_{\mathrm{MOD}}$ sofreria mais as conseqüências da internacionalização econômica.

Os investimentos públicos, entendidos pela teoria econômica como uma categoria de investimento autônomo, subjacente aos objetivos políticos, na abordagem de Fonseca Neto (2004) não seriam totalmente autônomos pelo fato dos gastos públicos em investimentos importantes para o desenvolvimento econômico terem sido adiados, devido à necessidade de manutenção de superávits primários.

Dessa forma, os $I_{P U B}$ dependeriam de dois componentes, um autônomo e outro que estaria relacionado à taxa de capitalização da dívida pública esperada pelo governo, que por sua vez dependeria das taxas de juros e de câmbio esperadas. 
Figura 4 - Esquematização da influência entre a economia globalizada e a brasileira

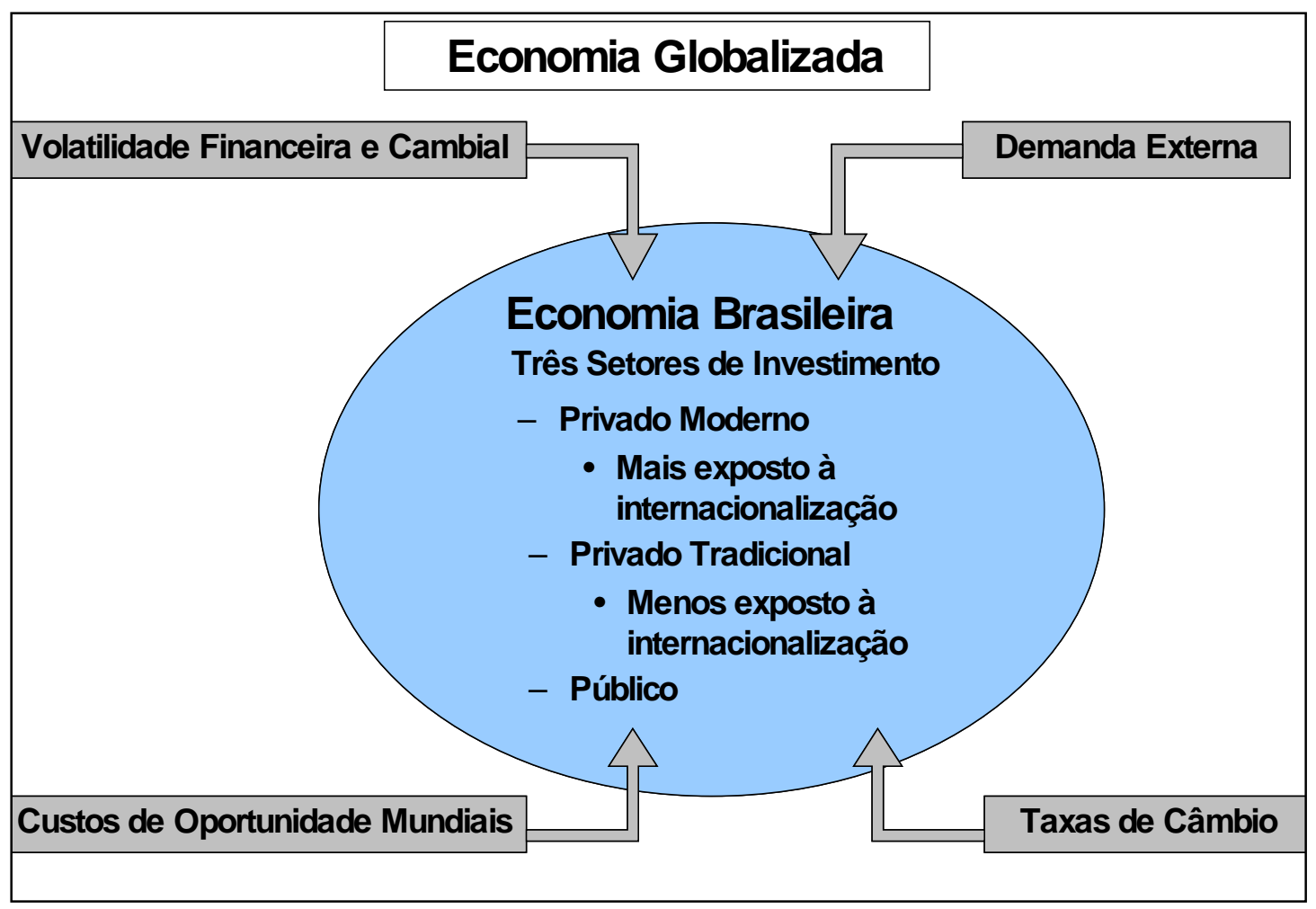

Com relação aos $\mathrm{I}_{\mathrm{TRAD}}$ e $\mathrm{I}_{\mathrm{MOD}}$, considera o princípio microeconômico geral de que esses investimentos ocorrem quando o retorno líquido esperado for maior do que as alternativas disponíveis - taxa de atratividade - sem mencionar atributos de liquidez ou risco.

No $\mathrm{I}_{\mathrm{TRAD}}$, o retorno esperado estaria mais relacionado à demanda interna, aos custos financeiros do capital de giro e suas volatilidades em moeda doméstica, como também a outros fatores que determinariam a categoria do $\mathrm{I}_{\mathrm{TRAD}}$ autônomo. $\mathrm{O}$ custo de oportunidade estaria representado pelas taxas internas de juros que alternativamente remunerariam o capital. 
No $\mathrm{I}_{\mathrm{MOD}}$, o retorno esperado dependeria da demanda externa, além da interna, e estaria influenciado pelas taxas do sistema financeiro e pela volatilidade cambial como também pelo nível de taxa de câmbio do período, além de outros fatores que determinariam o $\mathrm{I}_{\mathrm{MOD}}$ autônomo. Os custos de oportunidade seriam os rendimentos esperados de uma carteira de ativos financeiros internacionais.

Considerando-se os três setores, teríamos os determinantes do investimento e conseqüentemente do crescimento econômico, como sendo os níveis de demanda interna e externa observados; os custos financeiros de funcionamento do empreendimento; da volatilidade dos retornos esperados; e dos custos de oportunidade de investimento - no setor real da economia.

No caso das expectativas se frustrarem, o autor destaca que esse processo pode se revelar um mero surto de investimentos, sem sustentação posterior, decorrente de uma revisão e reversão de expectativas.

Com relação à incerteza, este autor define duas modalidades: a incerteza stricto sensu, relacionada à variabilidade dos determinantes diretos do retorno líquido como a taxa de câmbio e os preços; e incerteza lato sensu, relacionada ao ambiente dos negócios em geral, de natureza mais subjetiva e de difícil tratamento com modelos probabilísticos. 
Figura 5 - Explanação do cenário de expectativas e incertezas

\begin{tabular}{|c|}
\hline Incerteza Lato Sensu \\
\hline - Ambiente dos \\
Negócios em Geral \\
- Mais Difícil Utilizar \\
Modelos \\
Probabilísticos \\
\hline
\end{tabular}

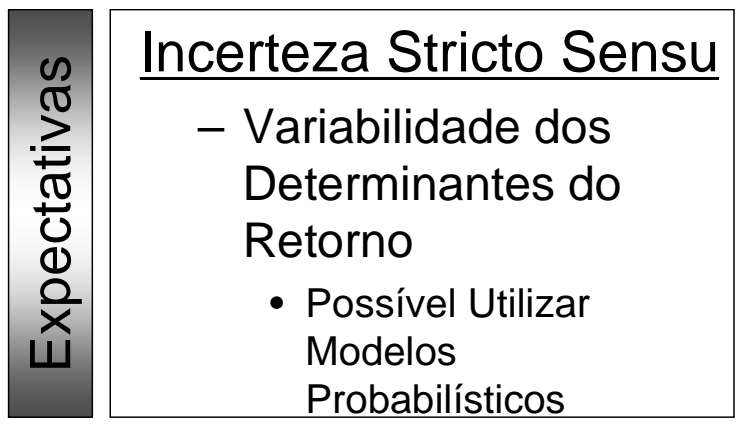

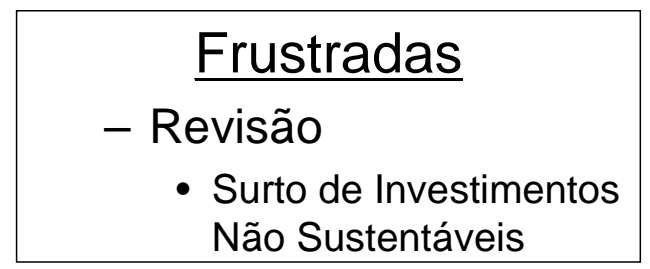

Os fenômenos das crises monetárias dos países emergentes e as bolhas dos mercados de capitais dos países desenvolvidos estariam no campo da incerteza lato sensu e suas influências sobre as decisões de investimento ocorreriam por meio do componente autônomo do investimento, como também, e especialmente, pela flutuação da demanda e volatilidade da taxa de câmbio e dos preços.

Na sequiência das discussões sobre a incerteza, Fonseca Neto (2004) introduz a questão da irreversibilidade dos investimentos, questionando o postulado neoclássico da reversibilidade.

Ou seja, para a teoria neoclássica convencional os agentes "desinvestiriam" os recursos cujos retornos estivessem inferiores às alternativas disponíveis, eliminando a importância da incerteza em relação aos eventos futuros. Dessa forma, ao se considerar a irreversibilidade dos investimentos, consolida-se a importância da incerteza, e a frustração das expectativas pode significar parcelas irrecuperáveis do investimento em toda sua vida útil. 
Assim, a incerteza stricto sensu poderia determinar que, em alguns casos, a postura mais racional seria adiar a decisão de investimento.

Fonseca Neto (2004), na seqüência, cita conclusões de trabalhos empíricos de outros autores, os quais identificaram que aumentos nas oscilações da taxa de câmbio contribuíram para reduzir os investimentos nos Estados Unidos, Europa e Coréia, como também em países em desenvolvimento, sendo nestes últimos, maior o impacto nos países de economias mais abertas e de mercados financeiros menos desenvolvidos.

Nos seus estudos empíricos utilizando modelos de autoregressão vetorial sobre os possíveis determinantes do investimento no Brasil entre os anos 1991 e 2004, concluiu que os impulsos de demanda interna e externa foram os principais determinantes, seguidos pela taxa de câmbio - significando que os preços em moeda nacional de bens de capital e bens intermediários são importantes para a decisão de investimento - e pelas volatilidades cambial e de preços - estas com menor intensidade do que a demanda e a taxa de câmbio, mas de influência sistemática e não desprezível. 


\subsection{2) INVESTIMENTOS DE BAIXA FLEXIBILIDADE EM AMBIENTE DE INCERTEZA NO MERCADO DE EMPREENDIMENTOS DE ESCRITÓRIOS DOS ESTADOS UNIDOS}

Rena Sivitanidou e Petros Sivitanides no texto "Does the Theory of Irreversible Investiments Help Explain Movements in Office-Commercial Construction?" abordam o mercado de empreendimentos de escritórios em regiões metropolitanas dos Estados Unidos entre 1982 e 1998, sob o ponto de vista da teoria neoclássica, incorporando os avanços teóricos recentes da taxa de atratividade de investimentos irreversíveis em ambientes de incerteza e risco. O foco dado pelos autores foi no comportamento dos investimentos no período e nas diferenças desse comportamento nos períodos pré e pós-recessão.

Os autores partem da premissa de que a volatilidade na economia influencia a taxa de atratividade dos investimentos de baixa flexibilidade e que sendo assim, essa volatilidade também exerce influência sobre as decisões de investimento. Essa premissa, ainda segundo os autores, é relevante para o mercado de empreendimentos de escritórios, dadas a baixa flexibilidade dos investimentos nesses empreendimentos e o ambiente de crescente volatilidade econômica no qual estão imersos.

Este trabalho considera um modelo de equilíbrio em um mercado competitivo onde o valor de investir se reduz em relação ao valor de não investir decorrente da irreversibilidade do investimento e da incerteza da demanda por espaços de escritórios.

Os aspectos teóricos são abordados a partir da teoria neoclássica tradicional, no qual o investimento em determinado mercado ocorre até que a receita marginal se iguala 
ao custo marginal. A partir da perspectiva que incorpora a irreversibilidade e a incerteza, como também a conseqüente opção de se adiar os investimentos, tais investimentos se justificariam, e não seriam adiados, apenas até quando a receita marginal fosse maior do que o custo marginal.

No modelo desenvolvido pelos autores, as variáveis utilizadas foram: (i) a oferta de novos espaços de escritórios construídos; (ii) o fluxo de renda dos aluguéis (uma média dos aluguéis de cada mercado ajustada pela inflação e a taxa de ocupação); (iii) o crescimento da renda dos aluguéis esperado e a incerteza (retratado pela taxa de crescimento esperado do emprego nos escritórios e por sua volatilidade calculada pelo desvio padrão, ambos referentes aos últimos cinco anos); (iv) a taxa de desconto (Treasury Rate ${ }^{12}$ dos últimos dez anos ajustada pela inflação); (v) o custo de construção e desenvolvimento (retratado pelo índice do custo da construção das regiões metropolitanas estudadas, considerando preço dos terrenos).

Os resultados do modelo apresentaram significativa influência negativa da volatilidade do emprego em escritórios na decisão de investimento em construção de escritórios - quanto maior a volatilidade, maior a taxa de atratividade envolvida e, conseqüentemente, menor a disposição de investir - no período pós-recessão, como também foram importantes para a decisão, embora menos evidente, o fluxo de renda dos aluguéis; a taxa de crescimento do emprego nos escritórios; e a Treasury Rate.

A segunda conclusão do trabalho foi sobre a alteração do comportamento dos investidores nos anos noventa em relação aos anos oitenta, sendo os investidores nos anos noventa mais avessos ao risco, dado a recente quebra de mercado. Esta

\footnotetext{
${ }^{12}$ Taxa de juros do Tesouro dos Estados Unidos.
} 
conclusão estaria embasada na influência negativa da volatilidade do emprego nos escritórios na decisão dos anos noventa, diferentemente dos anos oitenta; e às fracas respostas do investimento ao fluxo de renda dos aluguéis e ao crescimento do emprego nos escritórios.

Finalmente é interessante observar que os autores encontraram uma diferença no tempo de conclusão do investimento de 3,4 a 3,6 anos no período pré-recessão para 2,0 a 2,2 anos no período pós-recessão, cuja explicação seria de que os projetos seriam menores e melhores gerenciados pós-recessão. 


\section{3) PRINCIPAIS ACONTECIMENTOS ECONÔMICOS DO CICLO EM ESTUDO, QUE POSSIVELMENTE INFLUENCIARAM NO MERCADO DE REAL ESTATE DE SÃO PAULO:}

Observando a premissa descrita por Rena Sivitanidou e Petros Sivitanides (2000) e apresentada no item 2.2.2, em que a volatilidade na economia influencia a taxa de atratividade dos investimentos de baixa flexibilidade e que, sendo assim, essa volatilidade também exerce influência sobre as decisões de investimento, entendemos a importância de identificar os principais acontecimentos econômicos do período do ciclo em estudo, que possivelmente influenciaram sobre o mercado imobiliário de São Paulo, dadas a baixa flexibilidade dos investimentos nesses empreendimentos e o ambiente de crescente volatilidade econômica no qual estão imersos.

Dessa forma, nosso período de análise se inicia em um momento delicado da economia e da sociedade brasileira, em 1993, no início do governo Itamar Franco, após a crise política que culminou com o impeachment do Presidente Collor de Mello.

Em 1994, ano no qual as fontes de incerteza relacionadas ao problema político do Governo Collor haviam sido superadas e o Governo Itamar Franco, com Fernando Henrique Cardoso no Ministério da Fazenda, davam início ao Plano Real.

Em 1995, poderíamos considerar que o evento positivo na composição das expectativas dos agentes seria o início do Governo Fernando Henrique Cardoso, com 
a continuidade do Plano Real, e a Crise do México e seus reflexos na economia brasileira seriam o "choque externo" negativo na composição dessas expectativas.

Em 1996 não houve nenhum "choque" significativo, enquanto o ano de 1997 foi marcado pela Crise da Ásia. 1998 era ano eleitoral, quando a economia brasileira foi novamente atingida por um "choque externo", a Crise da Rússia.

Em 1999, ocorreu a "blindagem” à contaminação da Crise da Rússia pelo acordo com o FMI (fundo monetário internacional) e a resposta positiva do mercado à liberação do câmbio.

No ano seguinte ocorreu o choque externo do estouro da bolha da NASDAQ, no quarto trimestre do ano.

O ano 2001 sofreu efeitos da queda da NASDAQ, da crise da Argentina e do "11 de Setembro". Enquanto o ano de 2002 foi caracterizado pelo final do mandato do Presidente FHC e da eleição do governo Lula, momento em que diversos investidores temiam mudanças bruscas das diretrizes do governo.

Em 2003, a política conservadora do governo Lula impactou positivamente nas expectativas dos agentes, apesar das inseguranças geradas pela guerra do Iraque.

O ano seguinte, 2004, não foi caracterizado por algum evento ou "choque" que pudesse influenciar as expectativas dos agentes de forma significativa. 


\section{3) COMPORTAMENTO DOS INDICADORES ECONÔMICOS DURANTE O PERÍODO DE 1994 A 2004}

Analogamente a autores previamente citados, que estabeleceram comentários sobre a semelhança de comportamento ou relação de causa e efeito entre de indicadores econômicos e o mercado imobiliário de alguma cidade ou país, a presente dissertação também fará uso de indicadores econômicos representativos para interpretar os ciclos imobiliários em edifícios comerciais de padrão corporativo na cidade de São Paulo.

Tendo em vista que grande parte das empresas ocupantes de espaços de escritórios de padrão corporativo na cidade de São Paulo são sedes ou centros administrativos de operações industriais, comerciais ou de serviços distribuídas por todo o território nacional, adotamos como premissa que, em média, as decisões tomadas em São Paulo são impactadas por indicadores econômicos do país como um todo e, portanto, a presente pesquisa não adota como prioridade a regionalização (ou segregação por região) na identificação e coleta dos índices econômicos representativos.

Com o intuito de identificar e observar, por ângulos distintos, o comportamento da economia brasileira a cada ano do período em estudo, identificamos séries de indicadores capazes de representar a economia local.

Vale comentar que, devido à estabilidade da moeda ocorrida em 1994 (plano real), alguns indicadores diretamente impactados por tal fato serão analisados somente após 1995. 
a) Produto Interno Bruto (PIB) brasileiro, para incluir o produto e a renda do país;

A obra de Vasconcellos e Garcia (2000) define o PIB como o somatório dos os bens e serviços finais produzidos dentro do território nacional em um dado período, valorizados a preço de mercado, sem levar em consideração se os fatores de produção são de propriedade de residentes ou não-residentes.

Desta forma, a importância da sua análise na presente pesquisa consiste na abrangência e representatividade deste indicador sobre o comportamento da economia brasileira.

Figura 6: Série histórica do PIB e da sua variação anual no ciclo em análise.

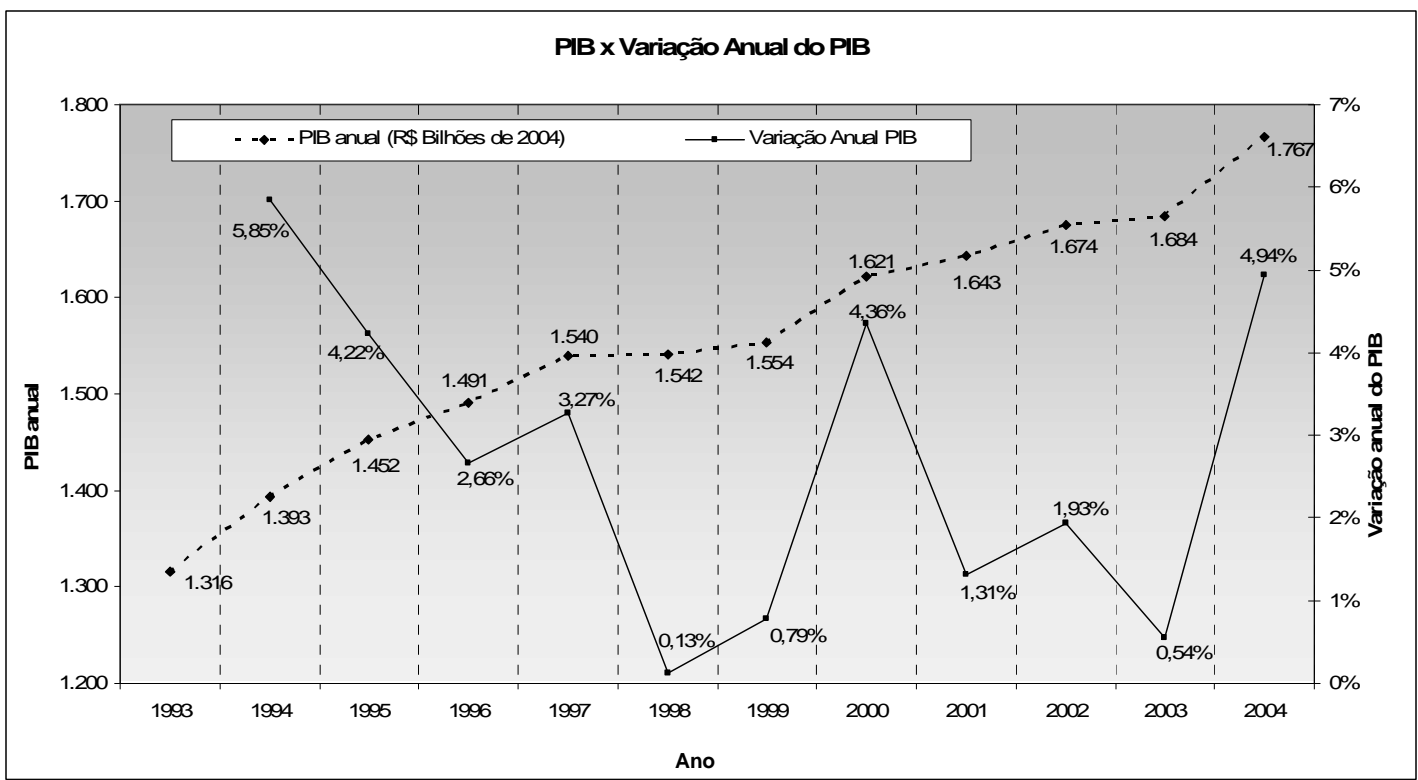

Fonte: Instituto Brasileiro de Geografia e Estatística (IBGE)

Adicionalmente, vale comentar neste momento que, quando se compara o valor corrente do PIB em momentos distintos, os mesmos incorporam a inflação. Segundo Vasconcellos e Garcia (2000), para medir o crescimento do produto físico em tempos 
diferentes, é necessário considerar que os preços mantiveram-se constantes. Desta forma, para excluir o impacto da inflação brasileira, todos os valores analisados foram conduzidos valores reais de 2004.

Ao analisar a variação anual do PIB, é perceptível um comportamento variável de zero a seis pontos percentuais, onde os momentos de maior crescimento ocorreram nos anos (i) de 1994, ano no qual as fontes de incerteza relacionadas ao problema político do Governo Collor haviam sido superadas e o Governo Itamar Franco, com Fernando Henrique Cardoso no Ministério da Fazenda, davam início ao Plano Real; (ii) de 2000, quando um alto volume de capital havia entrado no país como resultado das privatizações, por exemplo; e (iii) de 2004, momento em que o país passava por um período de recuperação e razoável estabilidade econômica.

É interessante observar o ciclo dividido em 2 períodos: de 1993 a 1997, momento anterior ao ingresso do alto volume de investimento direto estrangeiro e de 1998 a 2004, fase posterior ao ingresso deste capital no país.

Entre 1993 e 1997, período que apresentou maior estabilidade de altas taxas de crescimento do PIB, com taxa de crescimento acumulada de aproximadamente $17 \%$ e média de 4,25\% ao ano, enquanto no período entre 1998 e 2004, quando a taxa de crescimento do PIB acumulada cresceu aproximadamente $15 \%$ (em um período mais longo), com maior volatilidade e média de $2,45 \%$ ao ano. 
b) Investimentos Diretos Estrangeiros, para, além de incluir na análise a inter-relação do ambiente do país com o ambiente global, também destacar a sua influência em determinado subperíodo;

Figura 7: Série histórica do investimento direto estrangeiro no Brasil no ciclo em análise.

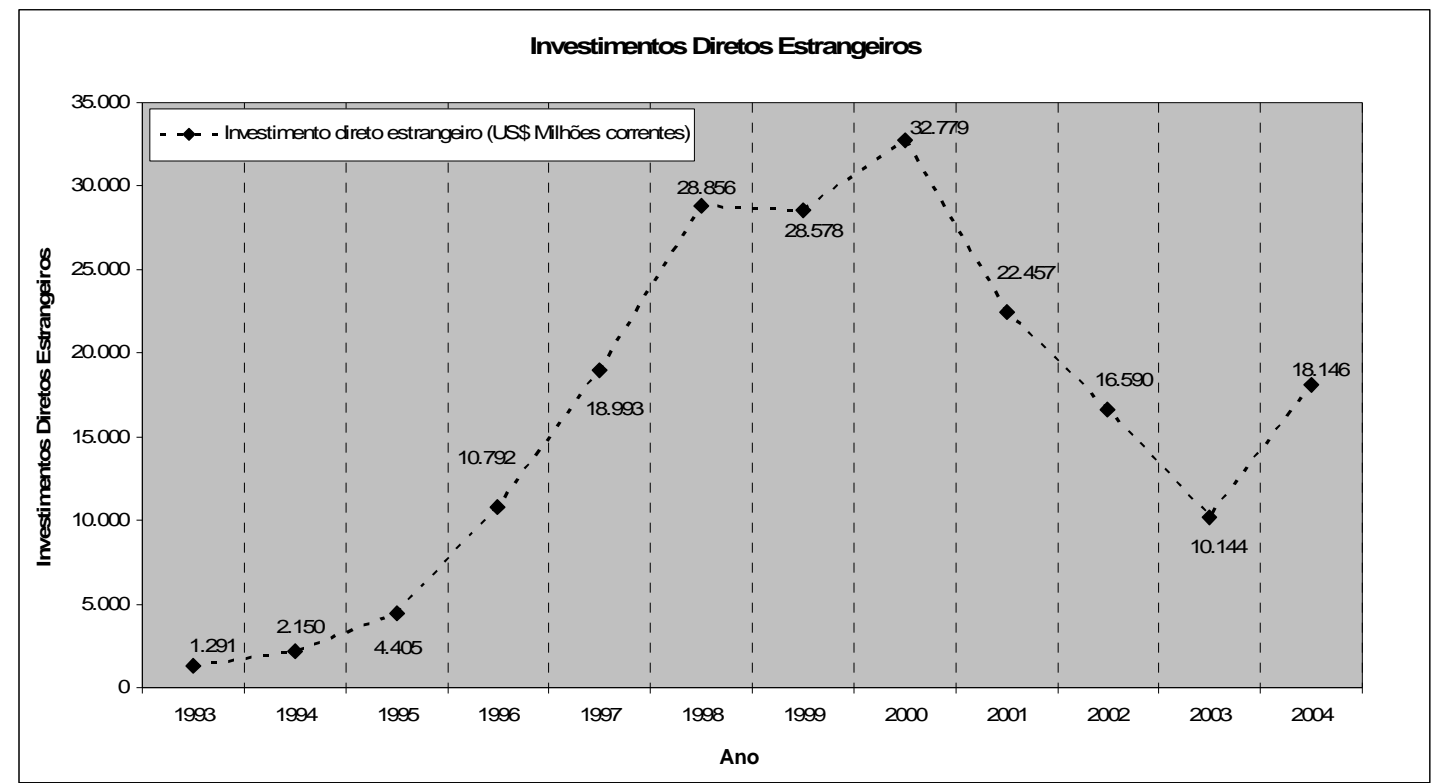

Fonte: Banco Central do Brasil

Percebe-se um crescimento expressivo da curva no período central do ciclo. Segundo informações do Banco Central, entre 1998 e 2001, os investimentos estrangeiros somente nas privatizações somaram aproximadamente 23 bilhões de dólares. Grande parte das empresas que ganharam as privatizações, as instituições financeiras e bancas de advogados que participaram do processo, assim como outras empresas que entraram ou expandiram suas atuações no mercado brasileiro em decorrência das novas regulamentações ou mesmo diante das oportunidades que se criaram. 
Figura 8: Série histórica do investimento direto estrangeiro no Brasil no período entre 1996 e 2002 incluindo e excluindo o montante relativo às privatizações.

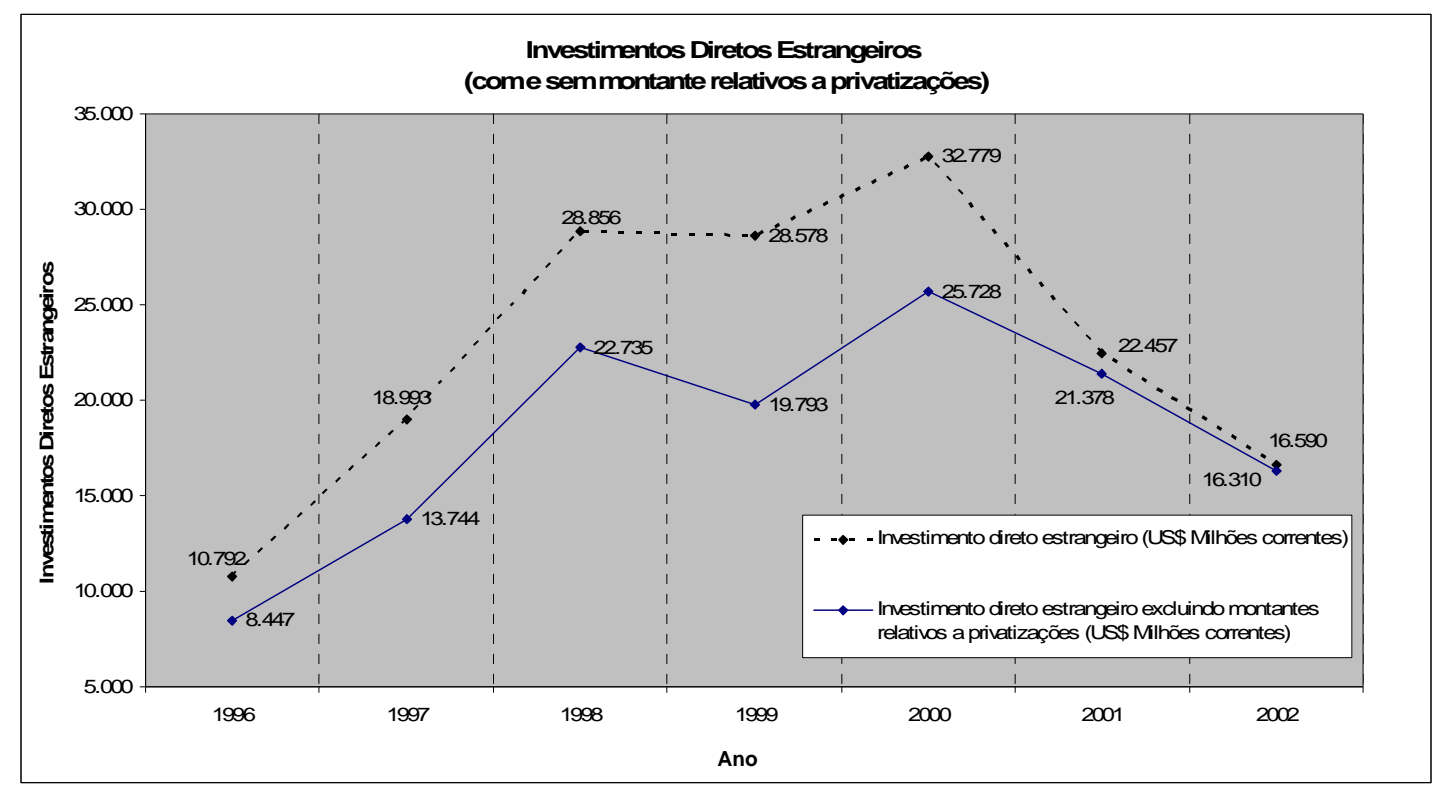

Podemos citar como exemplos entre muitas outras empresas, no setor elétrico: AES Eletropaulo, Enron, Bandeirantes Energia e CPFL; no setor de telecomunicações: Portugal Telecom, Telefônica, Vésper, Telecom Itália, Lucent Technologies, Nortel; no setor de gás: British Gas, Iquara e Agip; e no setor financeiro: Santander, JP Morgan/ Chase, Merrill Lynch e Goldman Sachs.

É importante destacar o setor de tecnologia da informação e Internet, que em outro processo concomitante ao das privatizações e abertura da economia, também contribuíam muito para a demanda de escritórios até o estouro da bolha da NASDAQ. Relacionamos especialmente as empresas Terra, UOL, Microsoft, Cisco, Oracle, Citrix Systems, BMC Softwares, $\mathrm{EMC}^{2}$, entre outras. 
c) Taxas de Juros do Overnight/ SELIC:

A taxa em questão é divulgada pelo Comitê de Política Monetária (COPOM) e possui significativa importância na economia, uma vez que as taxas de juros cobradas pelo mercado são balizadas pela mesma.

A taxa "overnight" do Sistema Especial de Liquidação e Custódia (SELIC), expressa na forma anual, é a taxa média ponderada pelo volume das operações de financiamento por um dia, lastreadas em títulos públicos federais e realizadas no SELIC, na forma de operações compromissadas. Em outras palavras, constitui-se na taxa básica utilizada como referência para transações de títulos públicos no mercado financeiro.

Segundo Vasconcellos e Garcia (2000), as decisões das corporações quanto à aquisição de máquinas, equipamentos, aumentos ou diminuição de estoques, de matérias-primas ou bens finais, de montantes de capital de giro, são usualmente determinadas levando em consideração as taxas presentes e futuras da SELIC. Se a expectativa com relação à trajetória da taxa de juros for pessimista, os agentes decisores das empresas tenderão a manter níveis baixos de estoques e mesmo de capital de giro no presente, uma vez que o custo de manutenção destes ativos poderá ser demasiadamente oneroso no futuro. Em paralelo, o patamar da taxa de juros também influencia as decisões de investimento em bens de capital, uma vez que, se a taxa estiver elevada, muitos projetos serão inviabilizados, pois os empresários tenderão a aplicar seus recursos no mercado financeiro. 
Adicionalmente, vale comentar que os consumidores também exercem um maior poder de compra quando a taxa de juros se encontra em níveis inferiores. A determinação do aumento da taxa de juros representa um crescimento do custo de financiamento de bens de consumo e influencia na diminuição do volume de consumo das famílias.

Por outro lado, a fixação da taxa de juros doméstica se relaciona com a demanda de crédito junto aos mercados financeiros internacionais. Segundo Vasconcellos e Garcia (2000), partindo da hipótese de que todos os demais fatores permanecem constantes, se a taxa de juros no Brasil se tornar relativamente mais elevada que a dos EUA, ocorre uma tendência de maior demanda de crédito externo por parte das empresas brasileiras comparativamente à situação anterior. Concluindo, o movimento de capitais financeiros internacionais está condicionado, entre outros fatores, aos diferenciais da taxa de juros entre os diversos países.

Desta forma, analisaremos a mesma para incluir os impactos da taxa de juros referencial da economia brasileira tanto na oferta - nos custos dos financiamentos e no custo de oportunidade - como na demanda - na capacidade da taxa de juros determinar em certo grau o aquecimento ou desaquecimento do investimento e demanda agregada; 
Figura 9: Série histórica da taxa de juros referencial da economia brasileira (SELIC) no ciclo em análise.

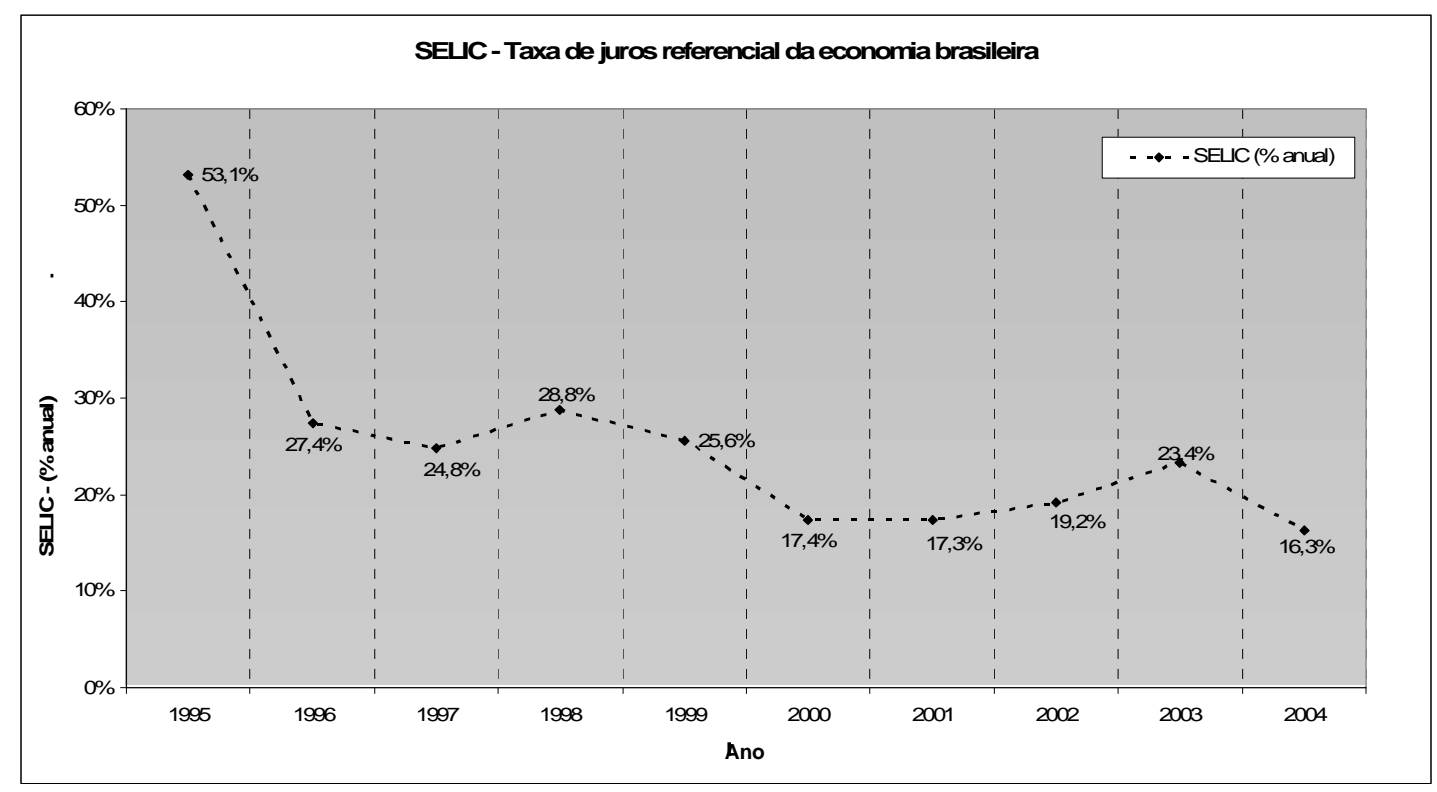

Fonte: Banco Central do Brasil

Embora com certa volatilidade, a taxa de juros brasileira demonstrou uma tendência de queda durante o ciclo, apresentando expressiva redução durante o início do Plano Real, sendo reduzida em aproximadamente 50\% de 1995 para 1996. Posteriormente, embora com menor intensidade, a taxa de juros foi, em média, sendo reduzida $1,4 \%$ ao ano, chegando a $16,3 \%$ ao final do ciclo. 
d) Variação Anual do Índice de Preço das Ações da Bolsa de Valores de São Paulo (IBOVESPA):

Sendo o índice que acompanha a evolução média das cotações das ações negociadas na Bovespa - Bolsa de Valores de São Paulo, o IBOVESPA é o valor atual, em moeda corrente, de uma carteira hipotética de ações, constituída em 1968 a partir de uma aplicação hipotética.

Figura 10: Série histórica da variação anual do IBOVESPA no ciclo em análise $^{13}$.

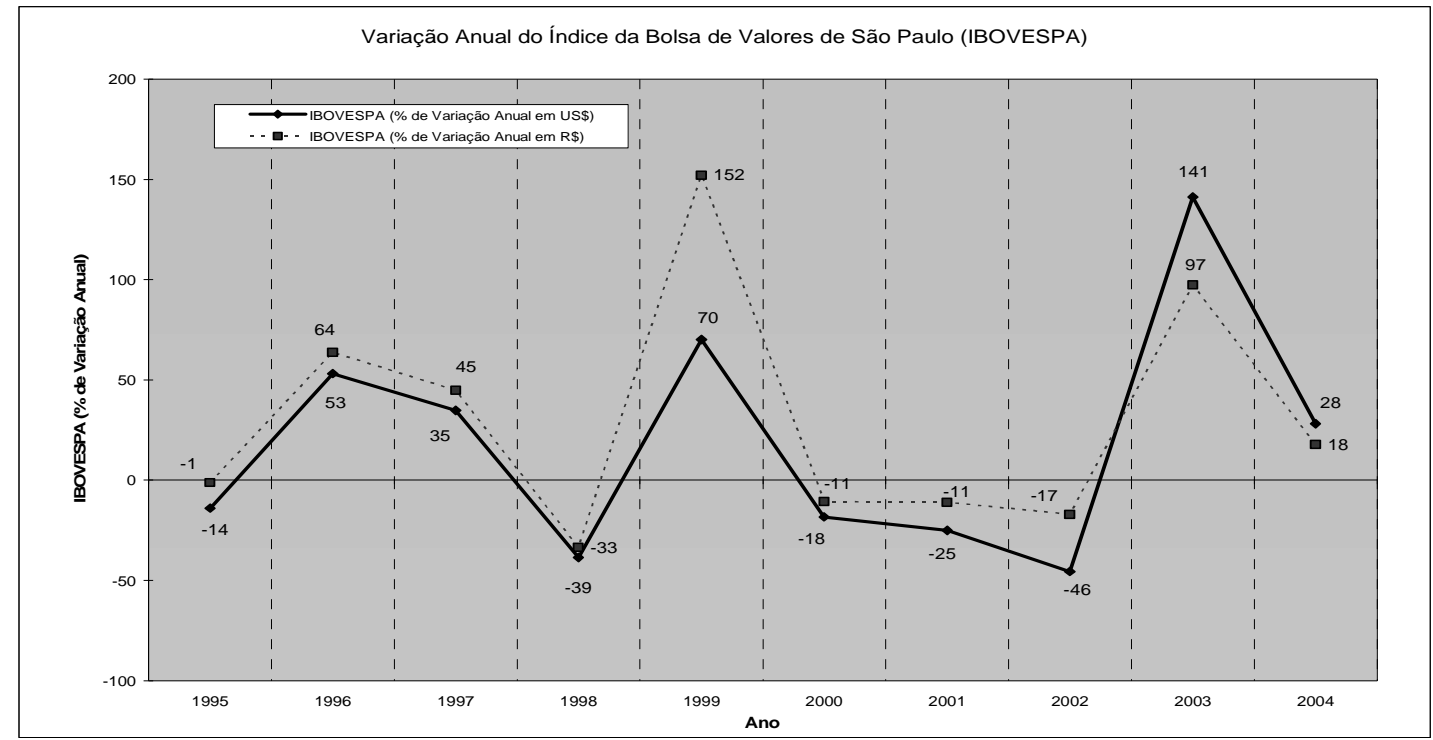

Fonte: Bolsa de Valores de São Paulo (BOVESPA)

No ciclo em estudo, ocorreram 3 momentos caracterizados como pontos de inflexão das curvas em alta (1996, 1999 e 2003) e 2 em baixa (1998 e 2002).

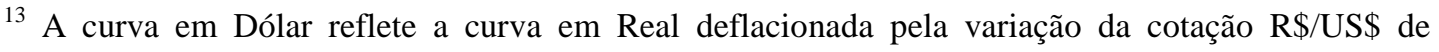
fechamento mensal - (taxa de venda - dólar comercial - fonte: Banco Central)
} 
Tendo em vista que o comportamento do IBOVESPA em Real apresenta um comportamento significantemente próximo do indexado ao Dólar, ambas as curvas são capazes de atender as expectativas da presente pesquisa.

Este índice de expressiva volatilidade será utilizado na presente pesquisa para representar o estado de confiança geral dos agentes econômicos na economia brasileira. 
e) IGP-DI (Índice Geral de Preços - Disponibilidade Interna), representando os índices inflacionários:

A inflação é definida como uma variação persistente e generalizada no índice de preços, ou seja, os movimentos positivos inflacionários são aumentos contínuos de preços.

Segundo Vasconcelos e Garcia (2000), a maneira tradicional para estudar a questão inflacionária é distinguir a inflação provocada pelo excesso de demanda agregada (inflação de demanda) da inflação por elevação de custos (inflação de custos).

A inflação de demanda está intimamente ligada à situação de pleno emprego de recursos, quando o aumento da demanda agregada de bens e serviços se torna presente e, com a economia já a plena capacidade, conduzem a elevação de preços, principalmente em setores produtores de insumos básicos.

Por outro lado, a inflação de custos pode ser associada tipicamente à oferta. Com o nível de demanda constante, os custos de determinados fatores importantes à economia sofrem aumentos. Assim, ocorre uma retração da produção e, conseqüentemente, da oferta, conduzindo a um aumento dos preços de mercado.

Os autores afirmam que os efeitos mais significativos do processo inflacionário ocorrem no perfil da distribuição de renda, no balanço de pagamentos, nas finanças públicas e na formação de expectativas.

Dentre os efeitos causados pelo processo inflacionário abordados pela obra em questão, vale destacar neste momento o efeito que altas taxas de inflação provocam sobre as expectativas de coletividade, ou seja, quanto ao futuro quadro econômico. 
Particularmente o setor empresarial é sensível à influência da inflação quando se abordam as expectativas sobre o futuro, dada a instabilidade e a imprevisibilidade de seus lucros.

Para estudar o comportamento da inflação brasileira no ciclo, foi coletada a série histórica do IGP-DI, como um exemplo de índice que represente o mesmo.

O índice IGP-DI da FGV reflete as variações de preços de todo o mês de referência. Ou seja, do dia 1 ao 30 de cada mês. Ele é formado pelo IPA (Índice de Preços por Atacado), IPC (Índice de Preços ao Consumidor) e INCC (Índice Nacional do Custo da Construção), com pesos de 60\%, 30\% e 10\%, respectivamente. O indicador apura as variações de preços de matérias-primas agrícolas e industriais no atacado e de bens e serviços finais no consumo.

Figura 11: Série histórica do IGPDI no ciclo em análise.

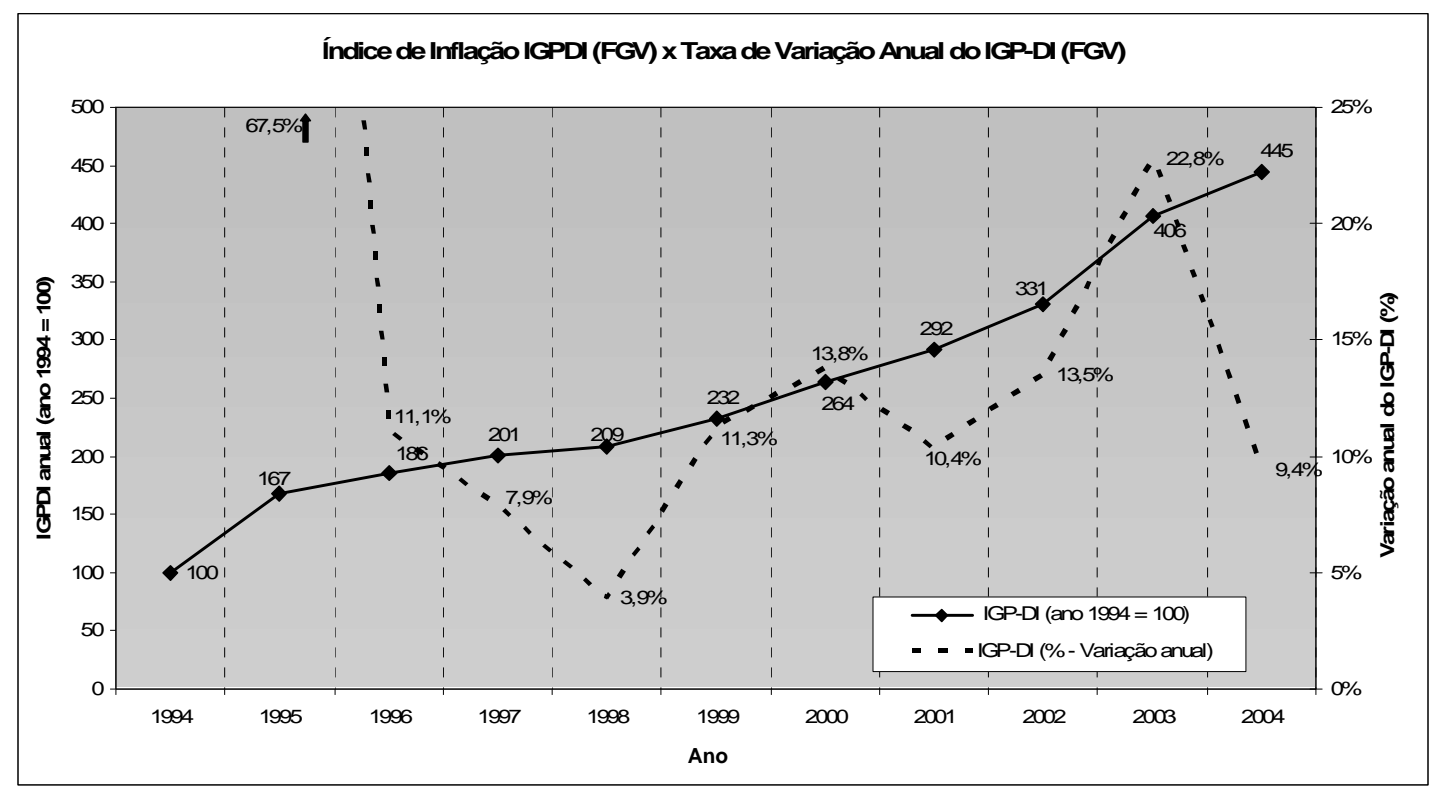

Fonte: Fundação Getulio Vargas (FGV) 
O ano de 1994 foi marcado por um "divisor de águas" sobre os índices inflacionários brasileiros, uma vez que o Plano Real conduziu o país de um cenário de superinflação para uma realidade de inflação controlada a partir deste momento.

De 1996 a 2002, é possível perceber a inflação oscilando entre quatro e quatorze pontos percentuais ao ano. $\mathrm{O}$ ano de 2003 indicou um aumento significativo da inflação, motivado pela variação cambial da moeda norte americana a partir de 2001, a qual impacta sobre o IPA (Índice de Preços por Atacado), que constitui 60\% do IGP-DI. Em 2004, a inflação voltou aos patamares anteriores, indicando o valor anual de nove pontos percentuais. 
f) a balança comercial brasileira, para representar o comportamento das exportações e importações;

Para objetivos de política econômica, é importante conhecer-se os fatores de influências mais significativas sobre as exportações e importações ${ }^{14}$.

Segundo Vasconcellos e Garcia (2000), as exportações agregadas são influenciadas pelas seguintes variáveis:

- Preços externos em dólares: Se os preços dos produtos brasileiros se elevarem no exterior, as exportações nacionais deverão se elevar;

- Preços internos em reais: uma elevação dos preços internos dos produtos exportáveis pode desestimular as exportações e incentivar a venda no mercado interno;

- Taxa de câmbio (reais por dólares): o aumento da taxa de câmbio deve estimular as exportações, seja (i) porque os exportadores nacionais receberão uma quantidade maior da moeda brasileira pela mesma parcela de dólares anteriores ou (ii) porque os compradores externos, com os mesmos dólares anteriores, estarão aptos a adquirir um maior número de produtos nacionais;

- Renda Mundial: um aumento da renda mundial estimulará o comércio internacional e, em conseqüência, as exportações nacionais;

\footnotetext{
${ }^{14}$ Para efeito de simplificação e tendo em vista a sua representatividade econômica global, adotaremos o dólar como a moeda estrangeira em análise.
} 
- Subsídios e incentivos às exportações: sejam estes de ordem fiscal ou financeira, representam um fator de estímulo às exportações.

Da mesma forma, seguem os principais fatores determinantes do comportamento das importações agregadas:

- Preços externos em dólares: Se os preços dos produtos importados se elevarem no exterior em dólares, haverá uma retração das importações brasileiras;

- Preços internos em reais: um aumento dos preços dos produtos internamente incentivará a compra dos similares no mercado externo, elevando as importações;

- Taxa de câmbio (reais por dólares): uma elevação da taxa de câmbio acarretará uma maior despesa aos importadores, pois pagarão mais em reais pelos mesmos produtos antes importados, os quais, embora mantenham os seus preços em dólares, exigirão mais moeda nacional por dólar;

- Renda e produto nacional: enquanto as exportações são mais afetadas pelo que ocorre na renda mundial, as importações estão mais relacionadas à renda nacional. Um aumento da produção e da renda nacional significa crescimento no país e uma maior demanda por produtos importados, seja como matériasprimas, bens de capital ou bens de consumo.

- Tarifas e barreiras às importações: a imposição de barreiras quantitativas (elevação de tarifas sobre importações) ou qualitativas (proibição da 
importação de determinados produtos, estabelecendo quotas e entraves burocráticos) ocasionam uma inibição nas compras de produtos importados.

Tendo em vista os principais impactantes nas exportações e importações brasileiras abordados por Vasconcellos e Garcia (2000), será analisado o comportamento da balança comercial brasileira no ciclo em estudo.

Figura 12: Série histórica da balança comercial brasileira no ciclo em análise.

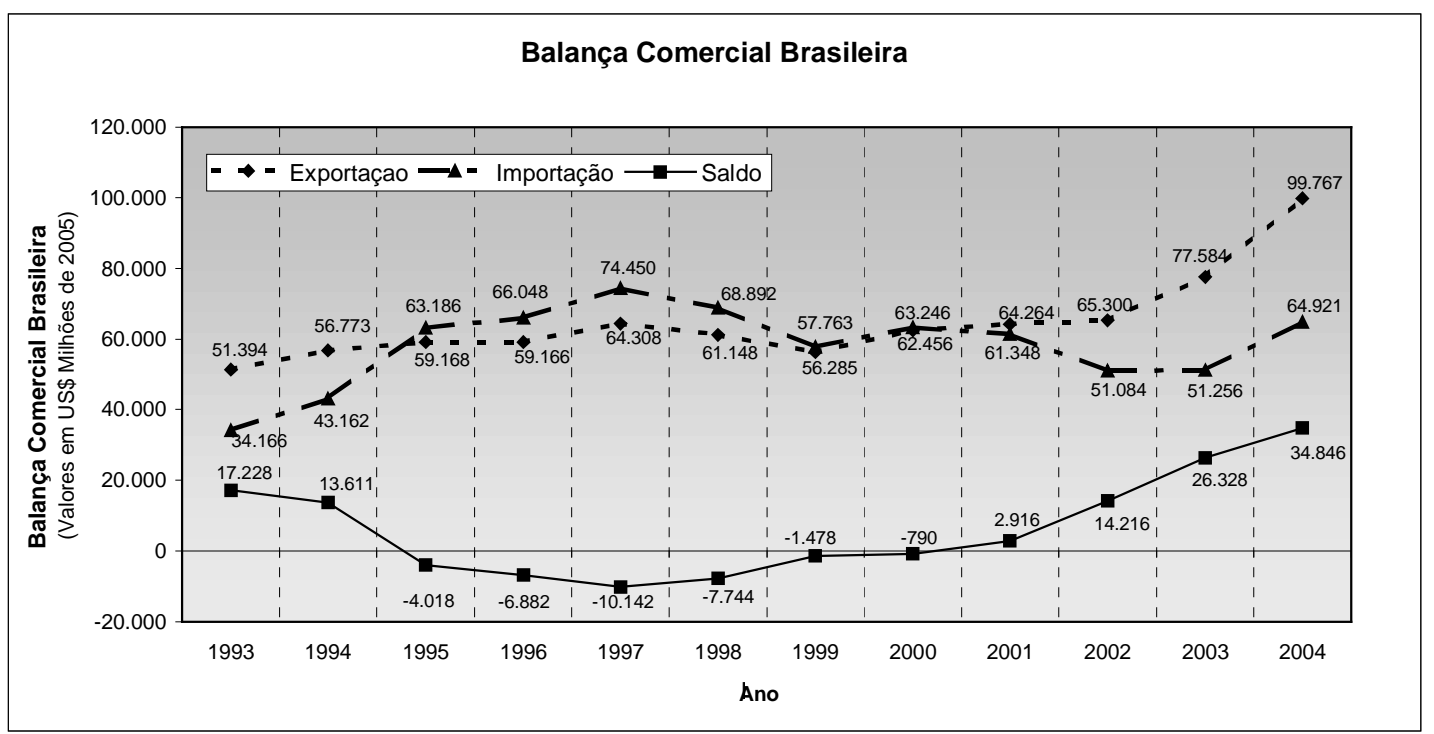

Fonte: Banco Central do Brasil

Tanto a importação como a exportação apresentam um significativo aumento de 1993 a 1997, seguidas de queda até o ano 1999 e um crescimento no ano seguinte.

A partir deste momento, as curvas apresentam comportamentos distintos, uma vez que a referente à exportação apresenta um crescimento acelerado até o final do ciclo, enquanto a relativa à importação apresenta uma redução entre 2001 e 2002, momento este em que inicia um processo de acelerado de crescimento. 
Tendo em vista os comportamentos supramencionados da exportação e da importação, a curva do saldo ou da diferença entre ambas, inicia o ciclo em um processo de queda que perdura até 1997, quando inicia um crescimento ininterrupto até o final do ciclo. 
g) a variação cambial do Real (R\$) frente ao Dólar comercial americano (U\$):

Quando dois países mantêm relações econômicas entre si, duas moedas passam a ser consideradas, exigindo a fixação da relação de troca entre ambas, ou taxa de câmbio.

Segundo Vasconcelos e Garcia (2000), a determinação da taxa de câmbio pode ocorrer tanto (i) institucionalmente, através de decisão das autoridades econômicas, com fixação periódica das taxas como (ii) através do funcionamento do mercado, onde as taxas flutuam automaticamente, em decorrência das pressões de oferta e demanda por divisas estrangeiras.

Analisaremos neste trabalho o comportamento da série histórica da cotação do Dólar comercial americano durante o ciclo em estudo.

Figura 13: Série histórica da cotação do Dólar comercial americano no ciclo em análise.

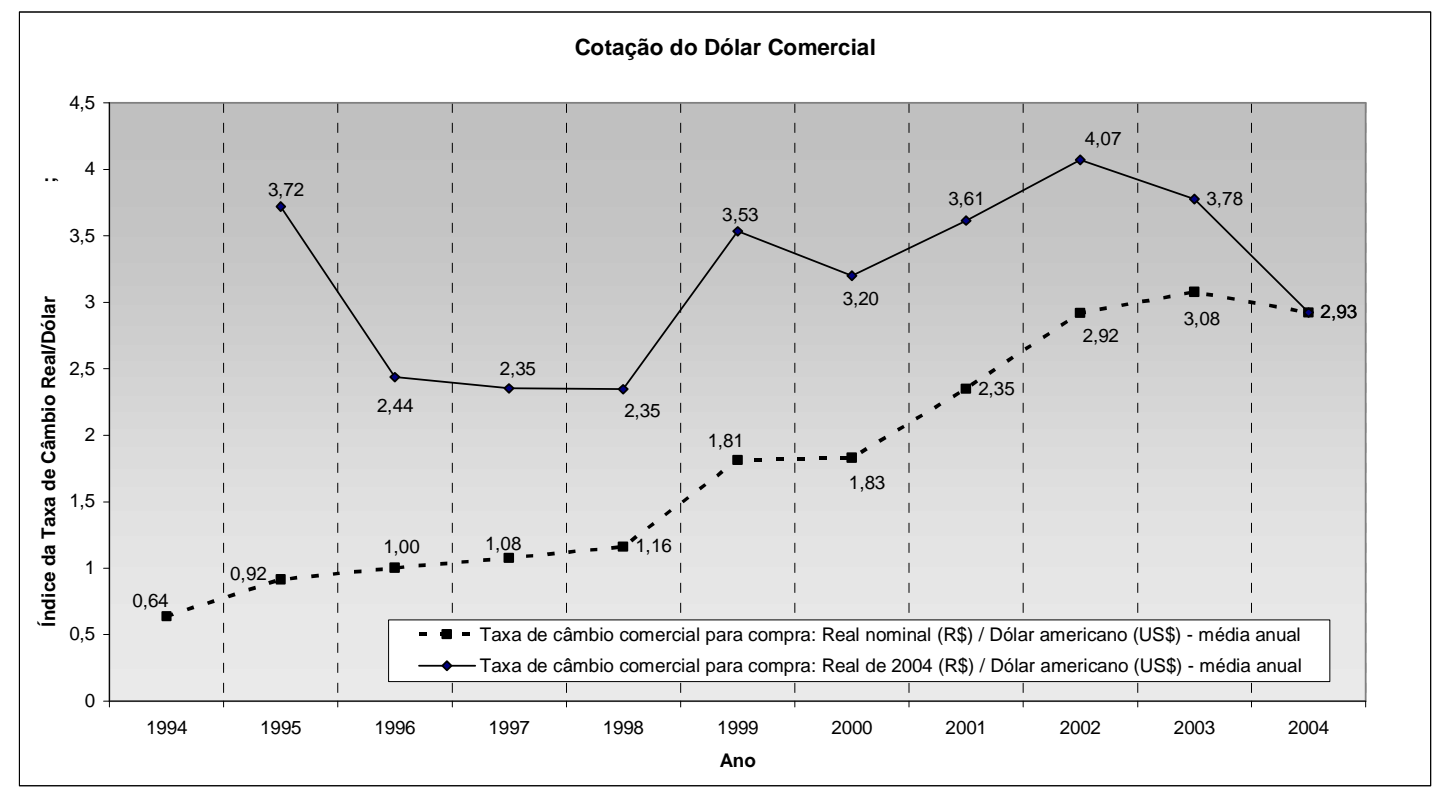

Fonte: Instituto de Pesquisa Econômica Aplicada (IPEA) 
O início do ciclo apresentou um crescimento inferior aos anos posteriores, registrando até 1998 um crescimento médio anual aproximada de 20 pontos, enquanto que, de 1999 ao final do ciclo, a média anual de crescimento foi de aproximadamente 46 pontos, considerando a moeda brasileira em reais nominais.

É importante perceber que um aumento do nível de preços internos (inflação interna) provoca uma redução da taxa real de câmbio, ou seja, ainda que a taxa nominal de câmbio permaneça constante, a inflação gera internamente uma queda no poder aquisitivo da moeda. A obra de Vasconcelos e Garcia (2000) afirma que os efeitos da perda de poder aquisitivo são (i) um desestímulo às exportações, uma vez que o preço do produto e serviço exportado não sofre correção equivalente à inflação e (ii) um estímulo às importações, uma vez que os bens e serviços importados, ao não serem corrigidos, praticam patamares de preços acessíveis.

Levando em consideração (i) as diferenças existentes entre as taxas de câmbio nominais e reais e (ii) ciente da expressiva inflação brasileira no ciclo, foi analisado também a taxa de câmbio com os valores da moeda brasileira em Real do ano de $2004^{15}$ e foi desconsiderada a inflação da moeda americana, uma vez que sua volatilidade foi pouco expressiva no ciclo, não afetando significativamente o comportamento dos indicadores.

As séries de indicadores apresentadas neste capítulo serão objeto de análise e manipulação no capítulo 6 , quando serão comparados com indicadores do mercado de escritórios de São Paulo.

\footnotetext{
${ }^{15}$ Utilizando o IGP-DI como o índice representativo da inflação brasileira.
} 


\section{4) DINÂMICA DE DESENVOLVIMENTO DO MERCADO DE ESCRITÓRIOS DA CIDADE DE SÃO PAULO:}

Conforme mencionado por Nobre (2000), apesar das semelhanças do crescimento do mercado imobiliário do setor terciário de São Paulo e outras metrópoles do mundo, existem diferenças nestes processos em função da peculiaridade de cada local.

Existem em São Paulo regiões bastante definidas que possuem concentrações de escritórios devido, principalmente, à localização, infra-estrutura e desenvolvimento histórico da cidade.

Figura 14: Mapa esquemático da cidade de São Paulo destacando suas principais regiões de escritórios

Tendo em vista que as séries históricas dos indicadores do mercado imobiliário, ou seja, a base de dados do presente trabalho, subdivide o mercado de escritórios da cidade de São Paulo em 4 grandes regiões e uma subdivisão adicional (todas as demais regiões), segundo o critério utilizado pela empresa CBRE (fonte dos dados

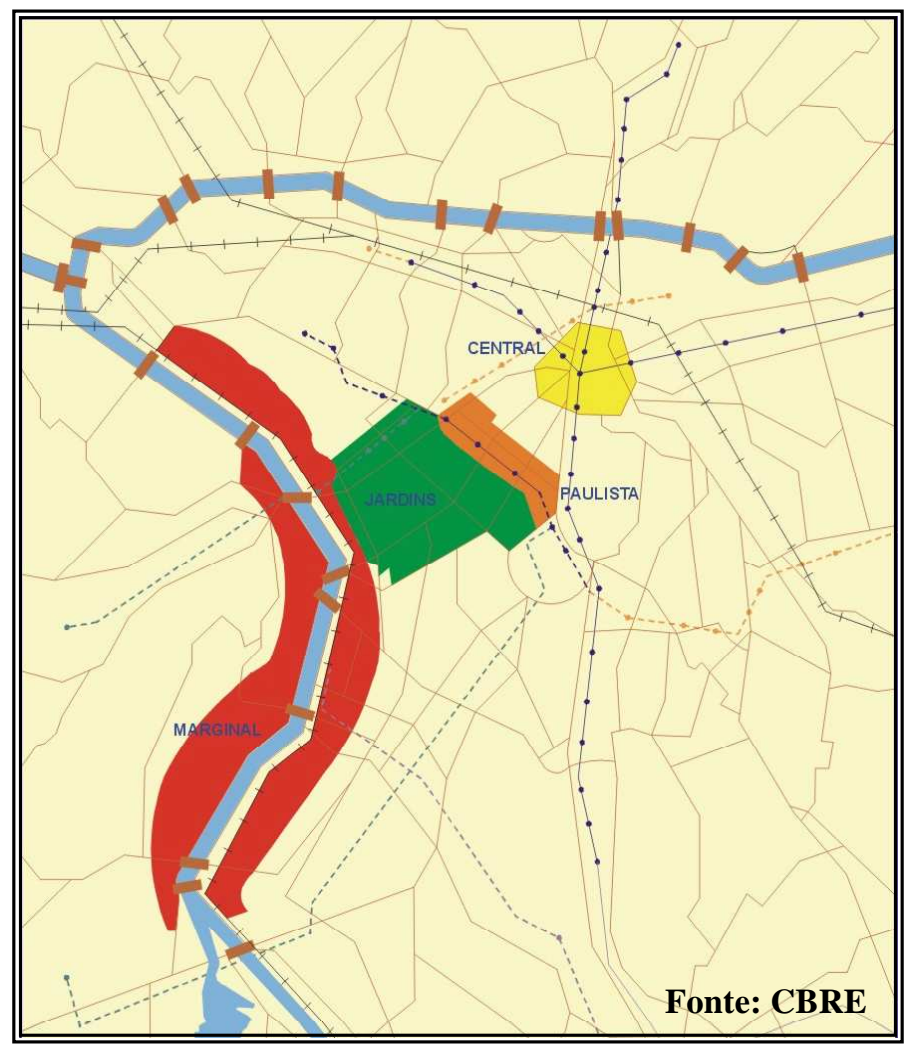

utilizados nesta pesquisa), discorreremos neste momento sobre as respectivas descrições e caracterizações do mercado de escritório de São Paulo, segundo o critério de divisão de regiões do banco de dados utilizado: 
a) Região Centro: compreende especialmente as áreas conhecidas como "Centro Velho" e "Centro Novo" de São Paulo. Nesta região localizam-se os primeiros edifícios de escritórios da cidade e o seu grande desenvolvimento se deu entre os anos de 1930 a 1960. Hoje, a composição do estoque da região é, predominantemente, de edifícios antigos, com conteúdo tecnológico ultrapassado e poucas possibilidades de re-desenvolvimento, tanto por problemas técnicos (andares com baixo pé-direito, sem possibilidade de instalação de piso elevado ou dutos de ar condicionado central) quanto por problemas comerciais (edifícios que pertencem a diversos proprietários, nos quais dificilmente seria possível chegar a um acordo quanto à viabilidade de reforma e quais seriam as bases comerciais para esse projeto). Um outro fator que caracteriza a Região Central de São Paulo é a carência de terrenos para empreender novos projetos. Em comparação com as demais regiões, poucas transações, tanto de venda como locação, ocorrem. As principais âncoras são a Bolsa de Valores, a Bolsa de Mercadoria e de Futuros, os órgãos do judiciário, como também dos governos municipais e estaduais.

Atualmente, a Região Centro é demandada principalmente por áreas administrativas de suporte de bancos e instituições financeiras, profissionais liberais como os advogados, universidades e faculdades, empresas de call center, órgãos da administração pública, do judiciário e empresas de pequeno e médio porte.

O ocupante que tem suas necessidades satisfeitas nessa região está interessado nas facilidades de acesso para pedestres por meio de transporte coletivo (metrô/ônibus), disponibilidade de serviços e comércio de apoio (agências bancárias, restaurantes, correios, infra-estrutura de telecomunicações por fibras ópticas, etc.), proximidade 
dos órgãos do judiciário e de governo, como também do antigo centro financeiro que tradicionalmente opera na região (Bolsa de Valores do Estado de São Paulo BOVESPA, e Bolsa de Mercadorias e Futuros - BM\&F), além dos baixos preços praticados nas transações imobiliárias em comparação com outras regiões.

Em termos gerais, a região central contempla uma pulverização muito grande de espaços para escritórios, principalmente direcionados à locação. Em sua grande maioria, são espaços pequenos, compostos por diversos conjuntos em edifícios comerciais consideravelmente antigos, sem sistemas de ar condicionado central e com baixo nível de especificações técnicas.

Finalmente, sobre a Região Centro, uma característica importante considerada na decisão de empreendedores e ocupantes é o processo de "declínio" ao qual está submetida. Assim, estes agentes do mercado em geral preferem outras regiões da cidade, cuja imagem transmita a mensagem de desenvolvimento.

b) Região Paulista: segundo Nobre (2000), até a década de 70, a região Centro e a região Paulista eram as únicas regiões na cidade que apresentavam características de centros de negócio, concentrando grandes edifícios de escritórios e comércio.

Devido à carência de terrenos, às dificuldades de re-desenvolvimento na Região Centro e ao crescimento que se observava na cidade de São Paulo, uma nova região atraiu o interesse de incorporadores e ocupantes: a Avenida Paulista. Com seu forte desenvolvimento ocorrendo nos anos 70, segundo dados da CBRE, aproximadamente $90 \%$ de todos os terrenos disponíveis na região foram desenvolvidos, principal razão de ter havido alguns poucos edifícios incorporados nessa região nos últimos anos. Por isso, em comparação às especificações técnicas exigidas pelos ocupantes 
atualmente, grande parte de seu estoque é considerado obsoleto, embora existam alguns bons edifícios, passíveis de reforma, ou mesmo edifícios que foram entregues nos últimos 10 anos e que apresentam especificações técnicas modernas.

Durante os anos 70 e 80, a Avenida Paulista foi considerada o centro financeiro da América do Sul, sendo escolhida como símbolo da cidade por seus habitantes. Contudo, segundo Nobre (2000), a partir de meados deste período, a concentração da Paulista começou a se modificar com a expansão do mercado de escritórios em direção Sul.

c) Região Jardins: esta região aqui definida compreende, principalmente, as avenidas Brigadeiro Faria Lima, Nove de Julho, Presidente Juscelino Kubitschek e imediações. Segundo informações da CBRE, o início do desenvolvimento desta região deu-se no final dos anos 70, na Av. Brigadeiro Faria Lima, sobretudo em razão do crescimento da cidade, da proximidade a importantes bairros residenciais e ainda, a um importante lançamento imobiliário na época, o Shopping Iguatemi.

Até o final dos anos 90, o estoque da região era, na sua grande maioria, composto por edifícios de pequenas lajes (pequenos e médios ocupantes), com especificações técnicas também ultrapassadas em relação às exigências atuais de mercado.

No final dos anos 90, a nova extensão da Avenida Brigadeiro Faria Lima, em virtude das desapropriações geradas para construção da Avenida, proporcionou o surgimento de novos terrenos com potencial para o desenvolvimento de novos empreendimentos. Neste novo trecho, foi presenciado o aparecimento de edifícios com especificações técnicas de alto nível, tais como tamanho de laje superior a $1.000 \mathrm{~m}^{2}$ e forte imagem 
corporativa, visando abrigar as sedes de instituições financeiras e transformar-se, com isso, no novo centro financeiro da cidade.

Adicionalmente, a nova extensão da Av. Brig. Faria Lima valorizou áreas como a Avenida Presidente Juscelino Kubitschek, a qual apresentou, a partir de 2000, novos empreendimentos de tecnologia avançada e imagem corporativa de qualidade.

d) Região Marginal: conforme menciona Nobre (2000), alguns dos fatores que levaram à promoção de grandes empreendimentos imobiliários do setor terciário na região Marginal do Rio Pinheiros foram a grande quantidade de terrenos baratos e vagos ali existentes, sua acessibilidade em função da importância da avenida marginal e de outras do sistema estrutural da cidade, e a proximidade a bairros residenciais de alta renda.

e) Outras Regiões: conforme critérios adotados pela fonte do banco de dados utilizado, este item agrupa as demais regiões de São Paulo que possuem pólos de concentração de edifícios de escritórios. Entre elas, pode-se citar Jabaquara, Água Branca e a região do Alphaville. Em comparação com as demais regiões, possuem uma importância secundária sob o ponto de vista de localização, ocupação (demanda) e investimento. Porém, algumas delas podem, cada vez mais, assumir um papel de destaque na cidade, em especial, a Região Água Branca ou Barra Funda, a seguir detalhada, a qual já vem atraindo o interesse de grandes e novas empresas em empreendimentos localizados próximos ao Terminal Intermodal Barra Funda e ao Shopping West Plaza. 


\section{Água Branca ou Barra Funda}

Segundo informações da base de dados utilizada, a Região Água Branca teve como indutor do desenvolvimento urbano a ferrovia e seu eixo e, como consequiência desse fato, uma ocupação ligada aos usos industriais, com depósitos, armazéns e galpões industriais.

Esta situação geográfica fez surgir então um segmento da cidade limitado por duas barreiras físicas de difícil transposição: a ferrovia e o Rio Tietê, onde a ocupação das áreas contidas nestes limites foi esparsa e desigual, caracterizada por um macro parcelamento, com grandes quadras que dificultam o deslocamento de pedestres. Adicionalmente, o fato de a retificação do Rio Tietê ter originado muitas áreas de domínio municipal, que permanecem sub-utilizadas, muitas delas objeto de cessões a terceiros.

Com a evolução industrial conduzindo à desativação das unidades existentes ao longo das ferrovias em favor de áreas maiores localizadas em regiões não urbanizadas, próximas às rodovias, a partir da década de 60 o bairro e suas proximidades perderam importância como pólo industrial da cidade.

Nesta época, os únicos pontos de travessia da linha férrea para os bairros eram os viadutos da Avenida Pacaembu e o viaduto da Lapa. Os viadutos da Av. Antártica e Av. Pompéia, eixos principais de transposição da ferrovia, foram implantados entre o final da década de 60 e início da década de 70, causando um hiato de quase uma década no desenvolvimento da região, que permaneceu praticamente desocupada, até a abertura, nos anos 70, da atual Av. Hermano Marchetti e Marquês de São Vicente, 
levando alguns empreendimentos comerciais e outros usos para suas margens, mas ainda de maneira tímida.

A proposta da Operação Urbana Água Branca a partir de 1990, abriu nova perspectiva de solução, buscando a ocupação racional da área e compatibilizando-a com sua indiscutível potencialidade mercadológica, dada principalmente pela:

- $\quad$ proximidade a vias de circulação de alta capacidade, como a Marginal Tietê, Av. Pacaembu, Av. Francisco Matarazzo e Av. Sumaré;

- proximidade a rodovias que conduzem ao interior do estado de São Paulo (Via Anhanguera e Bandeirantes);

- oferta de transporte de alta capacidade (trem metropolitano e metrô), facilitando o acesso do público de praticamente qualquer ponto da cidade;

- a linha oeste do metrô comporta aumento de demanda, favorecendo o adensamento da região;

- proximidade com bairros de bom padrão de ocupação que podem induzir a mudanças nos padrões atuais do local;

- existência de grandes áreas vazias ou sub-utilizadas;

- oferta de equipamentos de lazer e cultura de médio e grande porte (SESC Pompéia, Memorial da América Latina, Parque Fernando Costa, Play Center).

Todavia, o desenvolvimento do seu mercado de escritórios ainda se encontra tímido quando comparado às quatro regiões supramencionadas. 


\section{5) DESCRIÇÃO DOS INDICADORES DE REAL ESTATE DURANTE O PERÍODO DE 1994 A 2004 NA CIDADE DE SP}

Descreveremos neste capítulo os indicadores do mercado de real estate a serem analisados, considerando o período de 1994 a 2004.

Conforme já mencionado na introdução da presente pesquisa, no mercado de edifícios de escritórios, os dados estudados referem-se a séries históricas fornecidas pela empresa de consultoria imobiliária CBRE, cujos critérios para seleção da amostra são os seguintes:

a) edifícios de escritórios com lajes a partir de $250 \mathrm{~m}^{2} \mathrm{e}$ área útil total acima de $1.000 \mathrm{~m}^{2}$, com o objetivo de excluir lojas e pequenos edifícios, onde operam consultórios médicos, dentistas ou pequenas empresas, por exemplo;

b) edifícios providos de sistema de ar-condicionado central (ACC), uma vez que, segundo entendimentos da empresa fornecedora do banco de dados, a presença de tal sistema consiste em um grande "divisor de águas" de patamar de qualidade dos edifícios de escritórios do mercado de São Paulo. Vale comentar que aproximadamente $50 \%$ da metragem total dos edifícios da cidade de São Paulo são providos de sistema de ACC.

c) Regiões incluídas no estudo: Paulista, Jardins e Marginal Pinheiros. Contidas nas demais regiões, foi excluído da análise a região central, especialmente pela razão da não conformidade de seu estoque com os padrões de referência da amostra, e outras regiões como a Água Branca ou Barra Funda e a Vila 
Mariana, cuja oferta e demanda são pequenas o suficiente para não justificarem sua inclusão nas análises.

Vale comentar que, (i) tendo em vista que o foco desta pesquisa não consiste em estudar valores absolutos dos indicadores de escritórios, todavia aborda, entre outros itens, a interpretação do comportamento das curvas formadas pelas séries históricas e (ii) para possibilitar a manipulação de dados da CBRE com liberdade, os dados analisados do mercado imobiliário serão apresentados a partir de 1994, sendo associado ao ponto de partida o número índice 100.

Devido ao deslocamento de 2 a 3 anos que executado sobre o gráfico de Novo Estoque no capítulo 6 para avaliar o momento de tomada de decisão pela construção de novos edifícios, alguns gráficos abordarão um período equivalente anterior ao início do ciclo (1994). 
Tendo em vista os critérios de seleção da amostra supramencionados, segue uma breve apresentação das séries históricas que serão objeto de estudo nos próximos capítulos:

a) Novo Estoque - representa a quantidade de edifícios entregues a cada ano, ou seja, a oferta de espaços novos entregue ao mercado anualmente;

Figura 15: Série histórica do novo estoque no ciclo em análise ${ }^{16}$.

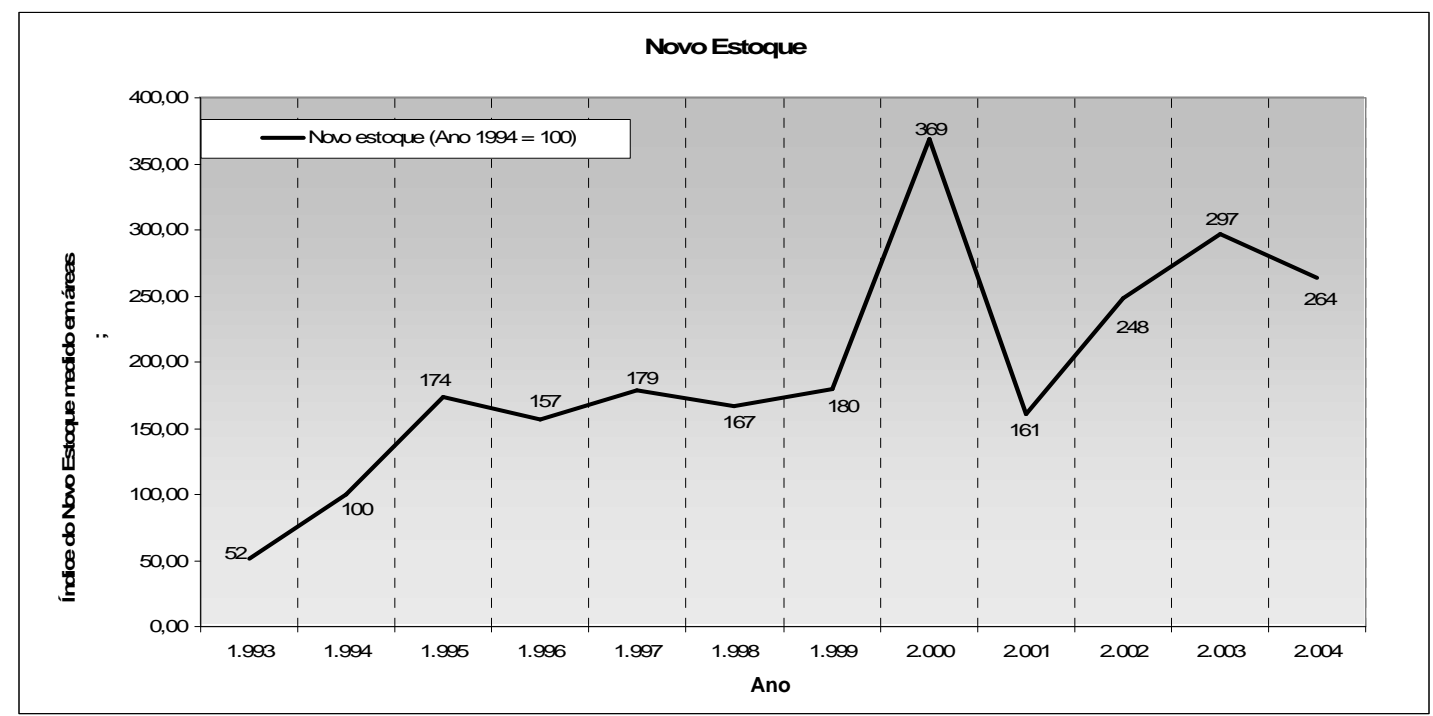

O volume de novo estoque apresentou um crescimento de 3,3 vezes de 1993 e 1995, manteve-se aproximadamente constante até 1999, porém o mercado de escritórios de São Paulo encontrou o seu recorde de entrega de novos edifícios em 2000, quando apresentou um crescimento acima de 7 vezes a apresentada no ano de 1993.

Após um período de redução no volume de entregas em 2001, o índice em questão voltou a apresentar aumento em 2002 e 2003, porém retornando a demonstrar reduções em 2004, último ano do ciclo em estudo.

\footnotetext{
${ }^{16}$ Conforme abordado no início do capítulo, para possibilitar a manipulação dos dados fornecidos com liberdade, os valores analisados referentes a novo estoque de edifícios de escritórios corporativos (medidos em metragens úteis) serão apresentados através de números índices, associando ao número índice 100 o ano de 1994.
} 
b) Absorção Bruta de Primeira e Segunda Mão - representa os espaços de primeira e segunda mão ocupados pela demanda;

Figura 16: Série histórica do índice da absorção de espaços de escritórios no ciclo em análise ${ }^{17}$.

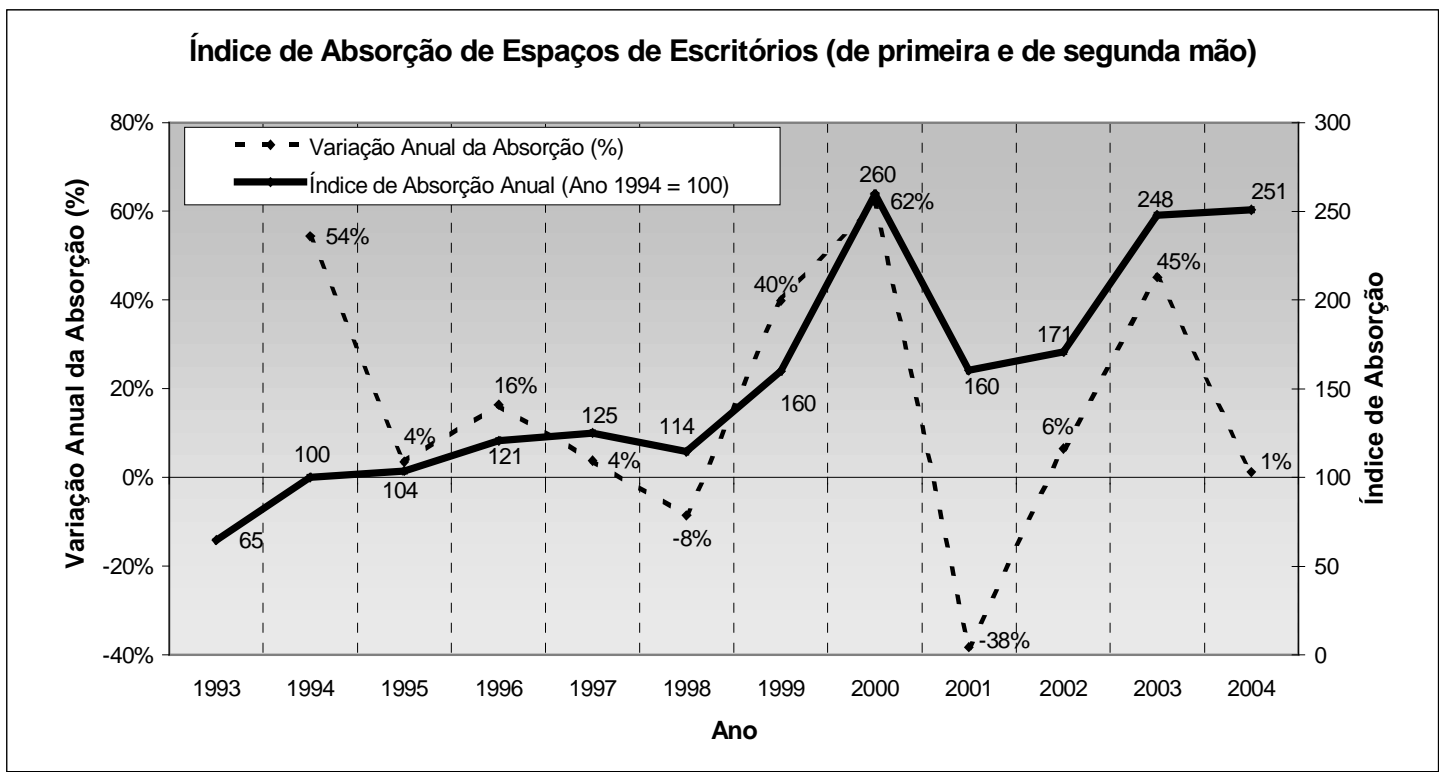

Como pode ser observado no gráfico acima, a demanda por escritórios nas regiões Paulista, Jardins e Marginal Pinheiros da cidade de São Paulo, representada aqui pela absorção dos espaços novos e usados, cresceu 4 vezes de 1993 a 2000. Logo em seguida, em 2001 e 2002 sofreu uma significante queda, voltando a crescer expressivamente em 2003 e 2004.

\footnotetext{
${ }^{17}$ Conforme abordado no início do capítulo, para possibilitar a manipulação com liberdade dos dados fornecidos, os valores analisados referentes à absorção de espaços de escritórios em edifícios corporativos (medidos em metragens úteis) serão apresentados através de números índices, associando ao número índice 100 o ano de 1994.
} 
c) Taxa de Vacância - representa a relação percentual entre o total dos espaços vagos (de primeira e segunda mão), e o Estoque Total, sendo este a quantidade de edifícios ou área útil de escritórios existente (vazios e ocupados).

Figura 17: Série histórica da taxa de vacância em espaços de escritórios no ciclo em análise.

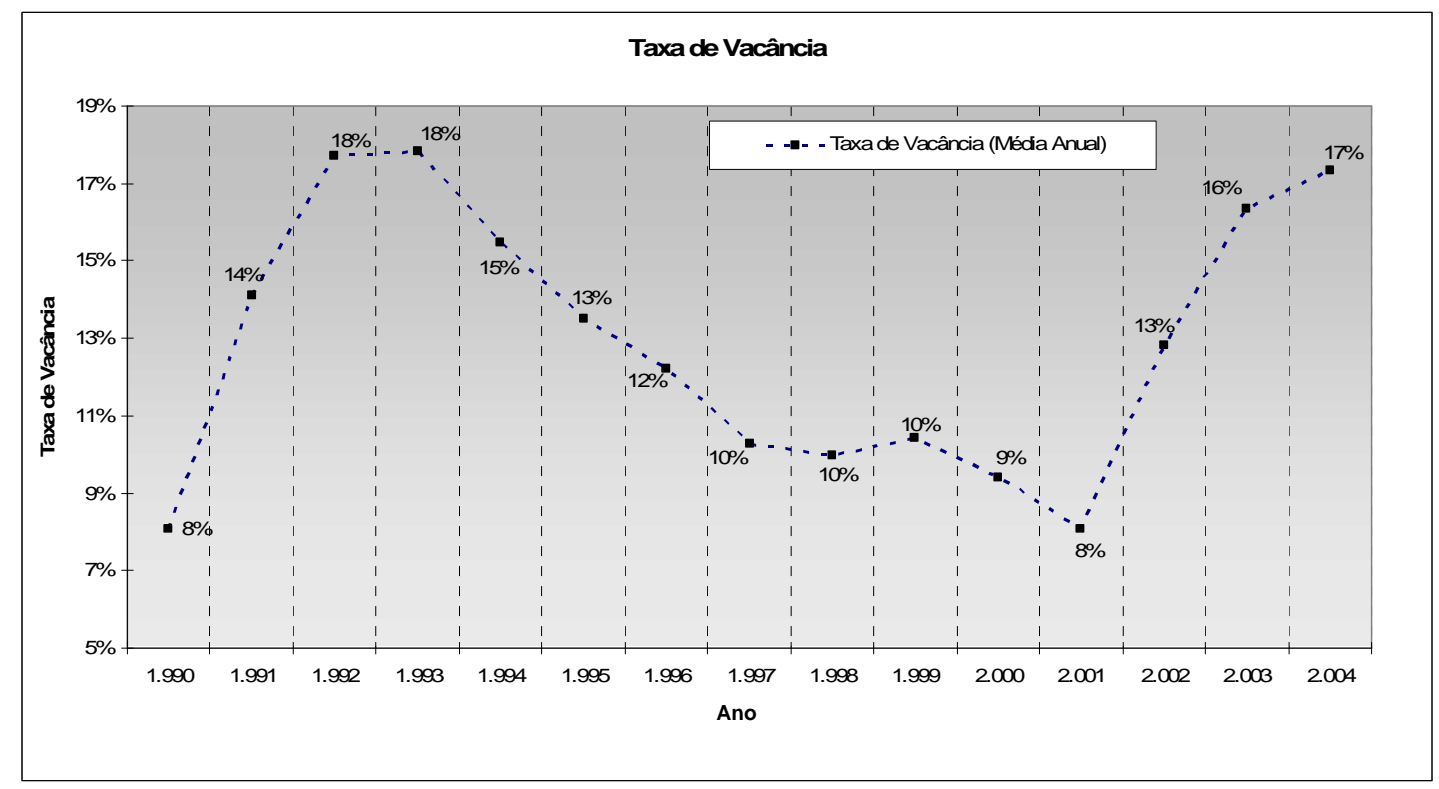

O ciclo inicia após um período de crise do mercado de escritórios de São Paulo, atingindo um ponto de inflexão da curva com taxa de vacância de $18 \%$ em 1993. A partir 1994, motivado pela estabilidade gerada pelo Plano Real, inicia-se um processo de recuperação do mercado até o final do ano de 2000, quando atinge outro ponto de inflexão da curva em $8 \%$.

Um período de oferta superior à demanda inicia-se a partir de 2001, acrescendo a taxa de vacância até atingir $17 \%$ no final do ciclo em estudo. 
Os indicadores apresentados serão objeto de análise e manipulação no capítulo 6 , quando serão comparados com indicadores econômicos. 


\section{6) RELAÇÃO ENTRE O MERCADO DE ESCRITÓRIOS DE SÃO PAULO E A ECONOMIA BRASILEIRA ENTRE 1994 E 2004}

Este capítulo analisa os movimentos ocorridos no mercado de empreendimentos de escritórios para locação (EEL) no período de 1994 a 2004, explorando os elementos próprios deste mercado, em relação ao contexto geral da economia, no qual os negócios do segmento específico de EEL acontecem.

Conforme mencionado no capítulo 5, para as análises, tendo em vista a adoção de um critério objetivo que identificasse um universo representativo de edifícios comerciais corporativos da cidade de São Paulo, foram considerados somente edifícios a partir de $250 \mathrm{~m}^{2}$ úteis de laje, providos de sistema de ar-condicionado central e área útil total a partir de $1.000 \mathrm{~m}^{2}$, nas regiões Paulista, Jardins e Marginal Pinheiros.

Segundo informações da fonte da base de dados, os edifícios abordados nesta pesquisa abrangiam, em dezembro de $2004^{18}$, 442 edifícios, totalizando em metros quadrados, $69 \%$ de dos edifícios ${ }^{19}$ comerciais da cidade providos de sistema de ar condicionado central e $37 \%$ dos edifícios ${ }^{20}$ com e sem sistema de ar condicionado central.

Entre os anos $1992^{21}$ e 2004, o estoque total de escritórios nas regiões Paulista, Jardins e Marginal Pinheiros apresentou um crescimento médio anual de 4,9\% ao

\footnotetext{
${ }^{18}$ Dezembro de 2004 foi o momento final do ciclo em estudo.

${ }^{19}$ Edifícios com lajes a partir de $250 \mathrm{~m}^{2}$ e áreas úteis totais acima de $1.000 \mathrm{~m}^{2}$.

${ }^{20}$ Edifícios com lajes a partir de $250 \mathrm{~m}^{2}$ e áreas úteis totais acima de $1.000 \mathrm{~m}^{2}$.

${ }^{21}$ Devido ao deslocamento de 2 a 3 anos executado sobre as curvas de Novo Estoque para avaliar o momento de tomada de decisão pela construção de novos edifícios, comentamos os acontecimentos do período equivalente anterior ao início do ciclo (1994).
} 
ano, enquanto a taxa de crescimento média do PIB brasileiro foi de $2,7 \%$ ao ano e da população ocupada na RMSP foi de $1,7 \%$ ao ano.

Tomando-se o ano de 1992 como base, o estoque total cresce abaixo do PIB e acima da população ocupada na RMSP até 1995. A partir de 1996 até 2004, não somente o crescimento do estoque total é maior do que o PIB e a população ocupada na RMSP como a diferença entre as taxas de crescimento aumenta sensivelmente. A questão que emerge desses dados é: Essa oferta encontrou contrapartida na demanda?

Devido à metodologia de estudo adotada, este capítulo primeiramente se concentrará na análise sob o ponto de vista da demanda, que será representada nas páginas seguintes pelo comportamento da absorção dos espaços de escritórios. Posteriormente, o estudo analisará o comportamento da oferta de espaços vagos de escritório nas regiões em estudo da cidade de São Paulo; 


\section{1) A DEMANDA}

Conforme mencionado no capítulo 2, o comportamento da demanda impacta na atratividade do setor e, portanto, é um importante determinante das decisões de investimento. Assim, passamos para uma análise do comportamento da demanda por escritórios no período de 1993 a 2004.

\section{Figura 18: Índice da absorção e sua variação anual.}

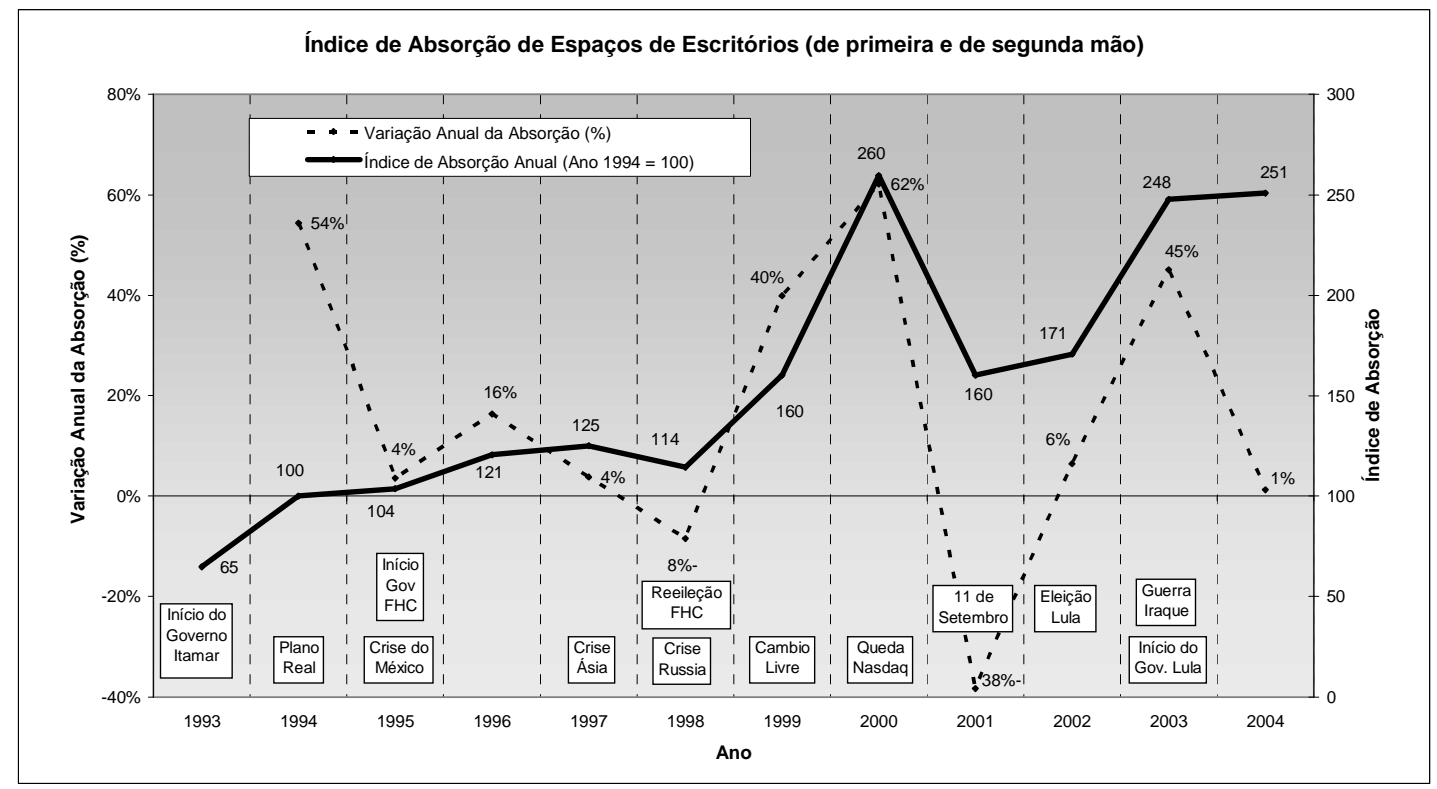

Como pode ser observado no gráfico acima, a demanda por escritórios nas regiões

Paulista, Jardins e Marginal Pinheiros da cidade de São Paulo, representada aqui pela absorção dos espaços de novos e usados, cresceu 4 vezes de 1993 a 2000. Logo em seguida, em 2001 e 2002 sofreu uma significante queda, voltando a crescer expressivamente em 2003 e 2004.

Conforme observado na bibliografia consultada (vide capítulo 2), percebem-se os “choques" que impactam no estado de confiança dos agentes econômicos, ou seja, na 
figura 18, sinalizam-se os eventos e "choques" que, sob uma análise preliminar, podem ter impactado no estado de confiança dos agentes.

Para evitar desvios de análise nos gráficos e conseqüente distorção das conclusões, questionei Terra (entrevista) sobre qual o período que uma empresa leva do momento da tomada de decisão pela relocalizaçao até a efetiva transação ${ }^{22}$. Seu posicionamento foi que, em média, estes prazos são de 2 a 7 meses $^{23}$, podendo ser divididos em: (i) de 1 a 4 meses em planejamento e pesquisa do imóvel e (ii) de 1 a 3 meses em negociações comerciais até a coleta das assinaturas sobre os respectivos contratos.

Tendo em vista as observações supramencionadas, discorreremos abaixo sobre uma descrição do ciclo em estudo.

Nosso período de análise se inicia em um momento delicado da economia e da sociedade brasileira, em 1993, no início do governo Itamar Franco, após a crise política que culminou com o impeachment do Presidente Collor de Mello. Em valores absolutos, os patamares dos anos 1992 e 1993 foram os menores de todo o período, crescendo significantemente em 1994, ano no qual as fontes de incerteza relacionadas ao problema político do Governo Collor haviam sido superadas e o Governo Itamar Franco com Fernando Henrique Cardoso no Ministério da Fazenda davam início ao Plano Real.

\footnotetext{
${ }^{22}$ Os dados de absorção fornecidos pela CBRE contabilizam que um espaço de escritório foi absorvido somente após o momento da conclusão da transação imobiliária, como a assinatura do contrato de locação ou de compra e venda, por exemplo.

${ }^{23}$ Terra (entrevista) citou, como exemplo, os períodos envolvidos em 4 transações recentes de seus clientes corporativos em São Paulo, para embasar sua resposta: (i) McGraw-Hill - 7 meses; (ii) Bain \& Company - 6 meses; (iii) Kodak -5 meses e (iv) At\&t -3 meses.
} 
Em 1995, poderíamos considerar que o evento positivo na composição das expectativas dos agentes seria o início do Governo Fernando Henrique Cardoso, com a continuidade do Plano Real, e a Crise do México e seus reflexos na economia brasileira seriam o "choque" externo negativo na composição dessas expectativas. Nesse ano a demanda cresceu $4 \%$ em relação ao ano anterior - abaixo do crescimento de $4,2 \%$ do PIB.

Em 1996 não houve nenhum choque e a demanda cresceu 16\%, para em seguida, em 1997, ano da Crise da Ásia, voltar ao patamar de 4\% de crescimento. Em 1998, ainda sob os efeitos da Crise da Ásia e ano eleitoral, a economia brasileira foi novamente atingida por um “choque” externo, a Crise da Rússia. Nesse ano a demanda caiu 8\%, variação de magnitude próxima daquela ocorrida no início do período, no fim do governo Collor e início do Governo Itamar.

Em 1999, com a “blindagem” à contaminação da Crise da Rússia pelo acordo com o FMI (fundo monetário internacional) e a resposta positiva do mercado à liberação do câmbio, a demanda cresceu $40 \%$. No ano seguinte, o crescimento foi de $62 \%$, o maior registrado em todo o período de análise, apesar do choque externo do estouro da bolha da NASDAQ, o qual ocorreu no quarto trimestre do ano.

No ano 2001, sob os efeitos da queda da NASDAQ, crise da Argentina e do "11 de Setembro", a demanda caiu $38 \%$, maior queda de todo o período.

Vale, neste momento, mencionar um exemplo citado por Terra (entrevista), referente ao seu cliente AT\&T, que alugou mais de $10.000 \mathrm{~m}^{2}$ no ano 2000 em São Paulo para ocupação e, nos anos seguintes, reduziu sua operação a aproximadamente $2.000 \mathrm{~m}^{2}$ na cidade. Adicionalmente, Terra (entrevista) complementou: “... todos os mercados 
mundiais são bastante dependentes da economia norte-americana. Especialmente no ano 2001, quando tínhamos uma expressiva atividade de tomada de espaços por parte das empresas de tecnologia, o mercado sentiu bastante os efeitos da desaceleração econômica".

Jaco (entrevista) mencionou “... o fenômeno da Internet e telefonia gerou, em pouco tempo, a devolução de grandes metragens por empresas ocupantes de espaços, uma vez que apresentaram desempenho inferior ao estimado previamente..."

O patamar de absorção encontrado em 2001 se manteve aproximadamente constante no ano seguinte, ano do final do mandato do Presidente FHC e da eleição do governo Lula, quando diversas empresas temiam a alteração da política econômica brasileira com a possível eleição do atual presidente, conforme mencionado por Jaco (entrevista): “... com o processo eleitoral do ano 2002, considerando o fato do Lula ter concorrido com sólida possibilidade de vencer, muitas empresas pararam seus processos de expansão ou relocalização, uma vez que as incertezas e inseguranças para o próximo ano eram significativas."

Desta forma, 2002 foi um ano ainda marcado pelos acontecimentos de 2000 e 2001 descritos acima, porém já demonstrando um pequeno sinal de recuperação, registrando uma absorção de $6 \%$.

Em 2003, a política conservadora do governo Lula impactou positivamente nas expectativas dos agentes, apesar das inseguranças geradas pela guerra do Iraque, e a demanda cresceu 45\%, o segundo maior nível do período estudado, mantendo o patamar elevado no ano seguinte quando não houve nenhum evento ou "choque" que pudesse influenciar as expectativas dos agentes de forma significativa. 
Grande parte desta absorção de 2003 ainda era (i) demanda reprimida dos anos anteriores, ou seja, eram transações que estavam para acontecer em 2001 e 2002, porém, devido às inseguranças do mercado, vieram a acontecer somente em 2003 e (ii) demanda gerada por relocalizações de empresas aproveitando a baixa dos valores de locação presente, ou seja, não eram expansões de empresas, mas sim mudanças de edifícios inferiores para mais modernos mantendo (ou até reduzindo) as metragens.

Neste momento, vale citar as palavras de Sartori (entrevista), gerente da divisão comercial da empresa fornecedora do banco de dados imobiliários da presente pesquisa, ao ser questionado sobre o impacto da queda da NASDAQ e do "11 de setembro" na absorção de espaços de escritórios em São Paulo:

"O impacto mais representativo destes acontecimentos ocorreu sobre as empresas multinacionais, as quais, em sua grande maioria, não permitiram e não aprovaram relocalizações após estes acontecimentos, inseguras com relação ao que poderia acontecer com a economia mundial posteriormente.

Nos anos seguintes, o mercado imobiliário ficou restrito e todos buscavam redução de custos e, muitas vezes, de área.

Como não existe uma relação rápida entre queda de absorção e queda de valores ${ }^{24}$, os proprietários levaram meses para assimilar a crise. Primeiramente ocorreu redução

\footnotetext{
${ }^{24}$ Este comentário de Sartori (entrevista) está de acordo com Grenadier (1995), o qual afirma a existência de uma considerável inércia dos proprietários de edifícios existentes para ajustarem os valores de aluguéis praticados em resposta a alterações no ambiente econômico.
} 
do número de transações e, somente após um tempo, foi constatado uma queda drástica dos valores de locação ${ }^{25}$ e aumento das carências oferecidas...”.

Ainda com relação ao impacto do "11 de setembro" na absorção de espaços de escritórios, vale destacar o paralelo qualitativo traçado em entrevista pelo professor Miranda (entrevista): “... este acontecimento contém um fator de origem sóciocultural que deve ser levado em consideração cada vez mais quando tratamos de absorção de escritórios, o terrorismo. Enquanto nos EUA, como resultado, houve uma pulverização entre outras cidades das atividades para segurança de operações, em São Paulo ocorre a violência, a qual afeta a forma de ocupação e a maneira das empresas escolherem seus edifícios corporativos. Como resultado, os empreendimentos em São Paulo que possuem amenidades, as quais permitem que os ocupantes não se exponham em ruas ou ambientes públicos terão certamente vantagem no momento da seleção".

Em 2004, a absorção se manteve praticamente estável, registrando um aumento de $1 \%$.

Com o intuito de tentar embasar justificativas potenciais para o comportamento da demanda por escritórios na cidade de São Paulo, serão apresentadas comparações da série de absorção de escritórios com indicadores econômicos representativos.

\footnotetext{
${ }^{25}$ Segundo Sartori (entrevista), em diversos casos, os valores transacionados chegaram a atingir neste período reduções significantemente expressivas, como no edifício Jorge Wallace Simonsen, onde o preço pedido de locação mensal era $\mathrm{R} \$ 65 / \mathrm{m} 2$ em maio de 2002 , quando o edifício teve sua obra finalizada (retirada do Habite-se) e os valores transacionados foram R $\$ 42 / \mathrm{m} 2$ em junho de 2003".
} 
Inicialmente, será apresentado Produto Interno Bruto (PIB) brasileiro ${ }^{26}$, um indicador abrangente, o qual registra uma média de comportamentos de diversos setores da economia brasileira através da medição do produto e renda do país.

Tendo em vista que, durante o ciclo de análise, houve um período de expressiva influência do capital estrangeiro no país durante o governo do Presidente Fernando Henrique Cardoso, analisaremos potenciais impactos do investimento direto estrangeiro no mercado imobiliário de São Paulo.

Posteriormente, considerando a crescente globalização ocorrida nas últimas décadas, é notório que a variação cambial do dólar frente ao real tem se tornado um fator determinante para o desenvolvimento de alguns setores da economia que dependem de exportação (ou de importação) de produtos ou de prestação de serviços para (ou de) outros países. Desta forma, observaremos na sequiência o impacto da variação cambial do dólar frente ao real e da balança comercial brasileira na absorção de espaços de escritórios.

Adicionalmente, tendo em vista que a taxa de juros SELIC caracteriza o impacto do juros referencial da economia brasileira tanto na oferta (nos custos dos financiamentos e no custo de oportunidade) como na demanda (na capacidade da taxa de juros determinar em certo grau o aquecimento ou desaquecimento do investimento e demanda agregada), tentamos identificar possíveis influências da variação desta taxa no volume de absorção de espaços de escritórios na cidade de São Paulo.

\footnotetext{
26 Terra (entrevista) acredita que o PIB brasileiro, o qual mede a atividade econômica do pais, influencia diretamente na absorção de espaços de escritórios de São Paulo, uma vez que entende que as decisões imobiliárias das empresas são sensíveis a este indicador.
} 
Por último, partindo-se da hipótese de que a oscilação da inflação brasileira gera um ambiente de incerteza para as previsões dos agentes tomadores de decisão das empresas ocupantes de espaço, obrigando-os, em diversos casos, a assumirem um maior patamar de risco ou a aplicar maiores coeficientes de segurança nas margens de lucro de suas novas unidades de negócio, compararemos o comportamento do mercado de escritórios com um índice inflacionário representativo (IGP-DI), com o intuito de verificar uma possível relação de causa e efeito. 
6.1.1) PIB brasileiro e investimentos diretos estrangeiros:

\subsubsection{1) PIB brasileiro:}

Notamos que o comportamento da absorção em todo o ciclo analisado apresentou uma certa semelhança de comportamento com relação ao PIB. Entre 1993 e 1997, período que apresentou maior estabilidade de altas taxas de crescimento do PIB, com taxa de crescimento acumulada de aproximadamente $17 \%$ e média de $4,25 \%$ ao ano, a semelhança das curvas demonstrou-se, aparentemente, maior do que no período entre 1998 e 2004, quando a taxa de crescimento do PIB acumulada cresceu aproximadamente $15 \%$ em um período mais longo, com maior volatilidade e média de $2,45 \%$ ao ano.

Figura 19: Produto interno bruto brasileiro e demanda do mercado de escritórios de São Paulo, medida pela absorção de espaços vagos.

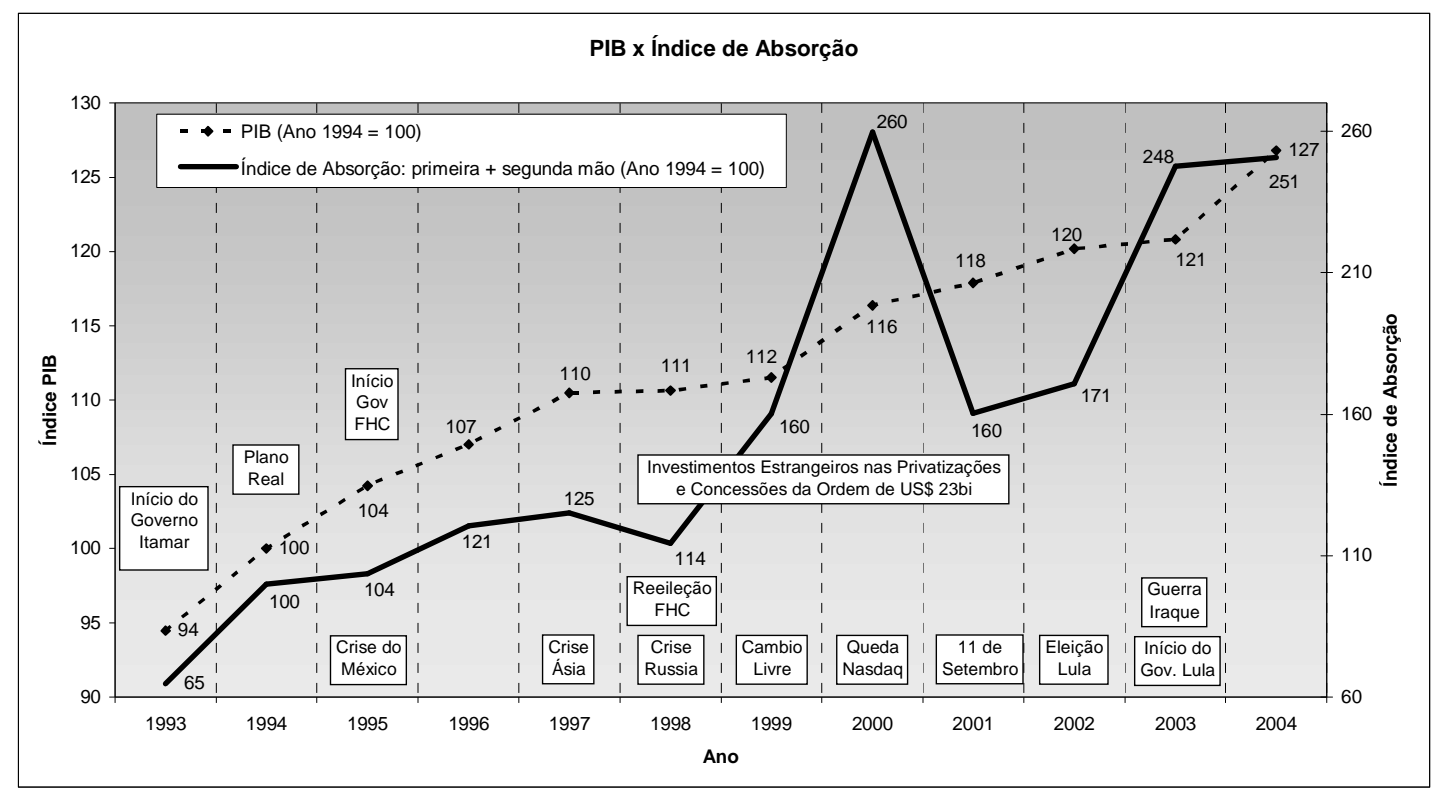


Assim, inferimos que, embora a renda e o produto agregado da economia brasileira possam ter determinado, em grande parte, o crescimento da demanda entre 1992 e 1996. O período de 1997 a 2004 demonstra apresentar outros fatores de maior influência na absorção de escritórios em São Paulo.

\subsubsection{2) Investimentos diretos estrangeiros:}

Na procura por fatores possam ter exercido maior influência na locação de escritórios em São Paulo no período de 1997 a 2004, investigamos os investimentos diretos estrangeiros no período.

Questionado sobre esta relação, o consultor Terra (entrevista) respondeu: "os investimentos estrangeiros no país tendem a influenciar positivamente os níveis de absorção, pois permitem a entrada de novas empresas no mercado local e de capital estrangeiro em empresas locais. Desta forma, a tendência é que estas empresas se desenvolvam e absorvam espaços adicionais."

A este respeito, o professor Miranda (entrevista) informou: "o Investimento Estrangeiro Direto, medido pelo Banco Central do Brasil, e os investimentos destinados exclusivamente às privatizações servem de referência de volume em um período onde o Brasil oferecia condições impares em termos de aquisição de empresas do setor energético (geração e distribuição) e outros setores públicos...”. Adicionalmente, complementou afirmando que “... estes segmentos geraram demanda que absorveu as ofertas existentes, assim como também a expansão das empresas “.com” da ocasião. Combinados os fatores, a absorção justificou preços elevados de locação, motivando coletivamente os incorporadores e investidores 
nacionais e, sobretudo, internacionais, como a Tishmann Speyer por exemplo, a novos negócios".

Como se pode perceber pela figura, potenciais relações de causa e efeito entre ambos os indicadores são evidentes:

Figura 20 - investimentos diretos estrangeiros e demanda do mercado de escritórios de São Paulo, medida pela absorção de espaços vagos.

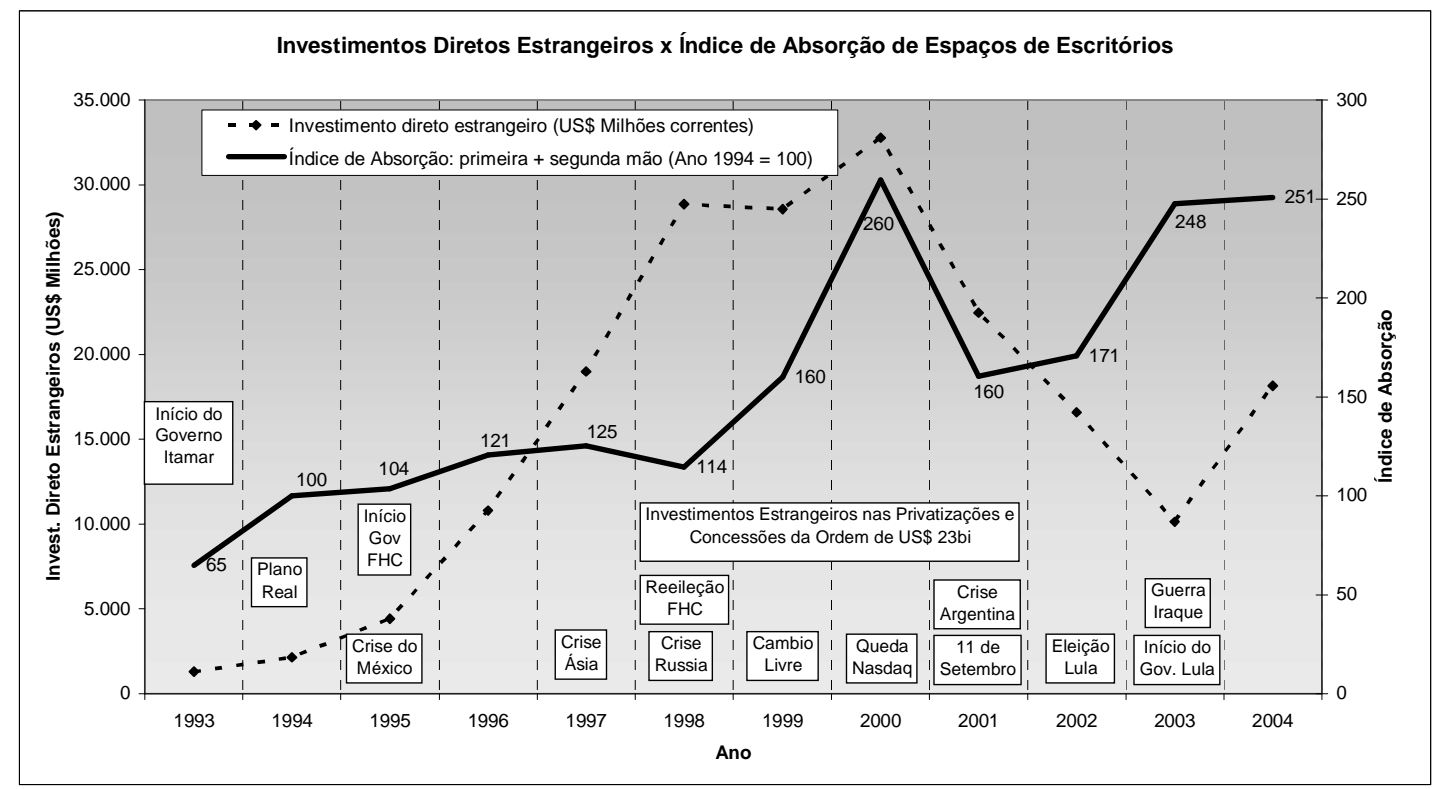

Há uma semelhança entre os movimentos da curva de investimentos estrangeiros diretos, os quais incluem tanto investimentos produtivos quanto especulativos, e a curva da absorção do estoque de escritórios. Ambas as curvas apresentam crescimentos notórios no final da década de 90 , atingindo os respectivos pontos de inflexão no ano 2000, quando iniciam processos de redução, os quais resultam em patamares inferiores em 2001. 
Conforme dados do Banco Central (apresentados na Tabela 2), entre 1998 e 2001, os investimentos estrangeiros somente nas privatizações somaram aproximadamente 23 bilhões de dólares.

Grande parte das empresas que ganharam as privatizações, as instituições financeiras e bancas de advogados que participaram do processo, assim como outras empresas que entraram ou expandiram suas atuações no mercado brasileiro em decorrência das novas regulamentações ou mesmo diante das oportunidades que se criaram, demandaram novos escritórios em São Paulo.

É possível citar como exemplos entre outras empresas, no setor elétrico: AES Eletropaulo, Enron, Bandeirantes Energia e CPFL; no setor de telecomunicações: Portugal Telecom, Telefônica, Vésper, Telecom Itália, Lucent Technologies, Nortel; no setor de gás: British Gas, Iquara e Agip; e no setor financeiro: Santander, JP Morgan/ Chase, Merrill Lynch e Goldman Sachs.

Tabela 2- representa o investimento estrangeiro direto relativo a privatizações de 1996 a 2002.

\begin{tabular}{|lr|}
\hline \multicolumn{2}{|c|}{ INVESTIMENTO ESTRANGEIRO DIRETO } \\
\cline { 2 - 2 } INGRESSOS RELATIVOS A PRIVATIZAÇÕES \\
\hline \multicolumn{3}{|c}{ (US\$ Milhões) } \\
\hline 1996 & 2.345 \\
1997 & 5.249 \\
1998 & 6.121 \\
1999 & 8.785 \\
2000 & 7.051 \\
2001 & 1.079 \\
2002 & 280 \\
\hline Total & 30.910 \\
\hline & \\
\hline
\end{tabular}


É importante destacar os setores de tecnologia da informação e de Internet, que em outro processo concomitante ao das privatizações e abertura da economia, também contribuíam muito para a demanda de escritórios até o estouro da bolha da NASDAQ. Relacionamos especialmente as empresas Terra, UOL, Microsoft, Cisco, Oracle, Citrix Systems, BMC Softwares, $\mathrm{EMC}^{2}$, entre outras.

A título complementar, seguem abaixo as palavras de Sartori (entrevista), ao ser questionado sobre o impacto dos investimentos diretos estrangeiros no mercado de escritórios de São Paulo: "O investimento direto estrangeiro foi fator decisivo até 2000. Entre 1994 e 1997, chegaram os bancos de investimentos como Goldman Sachs, Morgan Stanley, empresas que, inicialmente, ocupavam aproximadamente $300 \mathrm{~m} 2$ e, pouco tempo depois, possuíam 3.000 a $4.000 \mathrm{~m} 2$. Na sequiência, vieram as privatizações, como as empresas de telecomunicações. Podemos citar a BCP $(10.000 \mathrm{~m} 2)$ e a Intelig $(8.000 \mathrm{~m} 2)$ como exemplos."

\subsubsection{3) Conclusão (PIB brasileiro e investimentos diretos estrangeiros):}

Finalmente, com relação à demanda, é interessante notar que as semelhanças de comportamento mais significativas de curvas encontradas para todo o ciclo, foram com o PIB. Entretanto, ao se analisar dois períodos, notamos que no primeiro momento, entre 1993 e 1996, a semelhança de comportamento das curvas entre absorção e PIB aparenta ser maior, enquanto no segundo momento, entre 1997 e 2004, a semelhança de comportamento das curvas entre absorção e PIB aparenta ter sido menos significativa.

No segundo período, a curva de maior semelhança de comportamento encontrada com relação ao gráfico de demanda foi a curva do investimento direto estrangeiro, 
levando-nos a inferir que o baixo crescimento do PIB e a exposição da economia brasileira a sucessivos choques externos de grande magnitude, resultaram em volatilidade alta da demanda por escritórios decorrente do ambiente de maior incerteza. Ainda nesse segundo período, se tomarmos o final da década de 90 à 2001, notamos que a semelhança de comportamento entre as curvas de absorção e de investimento estrangeiro direto foi alta, reforçando a hipótese de que os elevados patamares de absorção estiveram relacionados especialmente às privatizações, concessões e empresas de tecnologia da informação que investiram no país. 


\subsection{2) Variação cambial do dólar frente ao real:}

Fonseca Neto (2004) menciona, através de trabalhos empíricos, que oscilações da taxa de câmbio contribuíram para reduzir os investimentos nos Estados Unidos, Europa e Coréia, como também em países em desenvolvimento, sendo nestes últimos, maior o impacto nos países de economias mais abertas e de mercados financeiros menos desenvolvidos.

Nos seus estudos empíricos utilizando modelos de autoregressão vetorial sobre os possíveis determinantes do investimento no Brasil entre os anos 1991 e 2004, concluiu que os impulsos de demanda interna e externa foram os principais determinantes, seguidos pela taxa de câmbio - significando que os preços em moeda nacional de bens de capital e bens intermediários são importantes para a decisão de investimento - e pelas volatilidades cambial e de preços - estas com menor intensidade do que a demanda e a taxa de câmbio, mas de influência sistemática e não desprezível.

Devido à crescente globalização durante as últimas décadas, a variação cambial do dólar frente ao real tem sido reconhecida como um fator determinante para o desenvolvimento de alguns setores da economia que dependem de exportação (ou de importação) de produtos ou de prestação de serviços para (ou de) outros países.

Ciente de tal dependência, comparamos a série histórica da variação cambial do dólar frente ao real com o índice de absorção de espaços de escritórios corporativos na cidade de São Paulo, com o intuito de tentar identificar semelhanças de 
comportamento entre as séries históricas, as quais poderiam ser justificadas por relações de causa e efeito.

Figura 21: Relação entre a variação cambial (Dólar frente ao Real) e a absorção de espaços de escritórios.

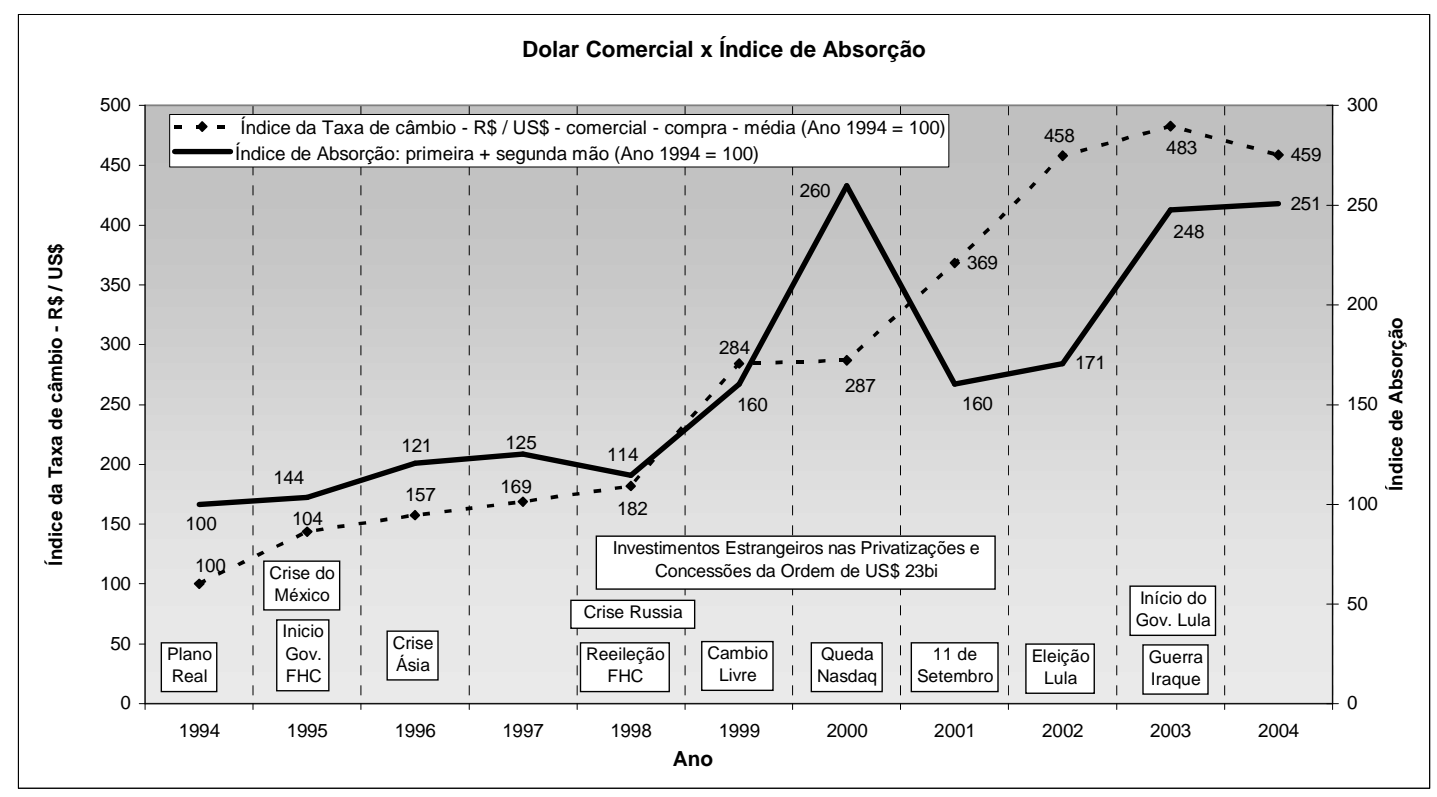

Percebemos uma certa semelhança no comportamento das curvas no período de 1995 a 1999 e de 2003 a 2004.

Vale relembrar que o período de 1998 a 2000 foi influenciado pelas privatizações e curvas de investimentos estrangeiros diretos e, com relação ao período de 2003 a 2004, conforme mencionado anteriormente, é importante salientar que grande parte desta absorção de 2003 e 2004 ainda era (i) demanda reprimida dos anos anteriores, ou seja, eram transações que estavam para acontecer em 2001 e 2002, porém, devido às inseguranças do mercado, vieram a acontecer somente em 2003 e (ii) demanda gerada por relocalizações de empresas aproveitando a baixa dos valores de locação presente, ou seja, não eram expansões de empresas, mas sim mudanças de edifícios inferiores para mais modernos mantendo (ou até reduzindo) as metragens. 
Possivelmente, esta maior confiança das empresas no período de 2003 a 2004, medidas pelo aumento do volume de absorção de espaços de escritório ${ }^{27}$ foi resultado de algum indicador econômico que seja diretamente influenciado pela variação cambial do dólar frente ao real.

Isto posto, na tentativa de encontrar uma justificativa para tal percepção, procurou-se identificar um indicador econômico que influenciasse na atividade empresarial de determinados setores da economia e que, adicionalmente, fosse impactado diretamente pela variação da cambial do dólar, de forma a poder ser considerada como causa de expansões ou relocalizações de escritórios empresariais.

Miranda (entrevista) acrescentou acreditar que a hipótese da relação da variação cambial nos EELs se constitui nítida em empresas que dependem diretamente da balança comercial para expansão das atividades de escritórios, preponderantemente empresas do segmento industrial que necessitem de espaços classe A para sua representação e mesmo operação.

\footnotetext{
${ }^{27}$ Uma relocalização de um escritório demanda investimentos, portanto entende-se que um aumento no volume de absorção de escritório registra uma maior confiança das empresas no mercado local.
} 


\subsection{3) Comportamento da balança comercial brasileira:}

Como a desvalorização da moeda brasileira gera uma diminuição de valor sobre os produtos brasileiros no mercado mundial, deduz-se que o aumento da taxa do dólar gera um aumento das exportações brasileiras e, possivelmente, uma maior confiança no mercado local de empresas que dependem deste indicador.

Sartori (entrevista) mencionou que a balança comercial brasileira impactou mais diretamente setores como logística, exportação e importação, enquanto Miranda (entrevista) acrescentou que a variação da taxa de importação impacta nos setores de comércio e serviços, enquanto a oscilação da taxa de exportação movimenta os setores industrial e comercial.

De fato, o gráfico abaixo aponta para a balança comercial como um possível motivador para o crescimento da absorção.

Figura 22: comportamento da balança comercial brasileira $x$ a absorção de espaços de escritórios em São Paulo

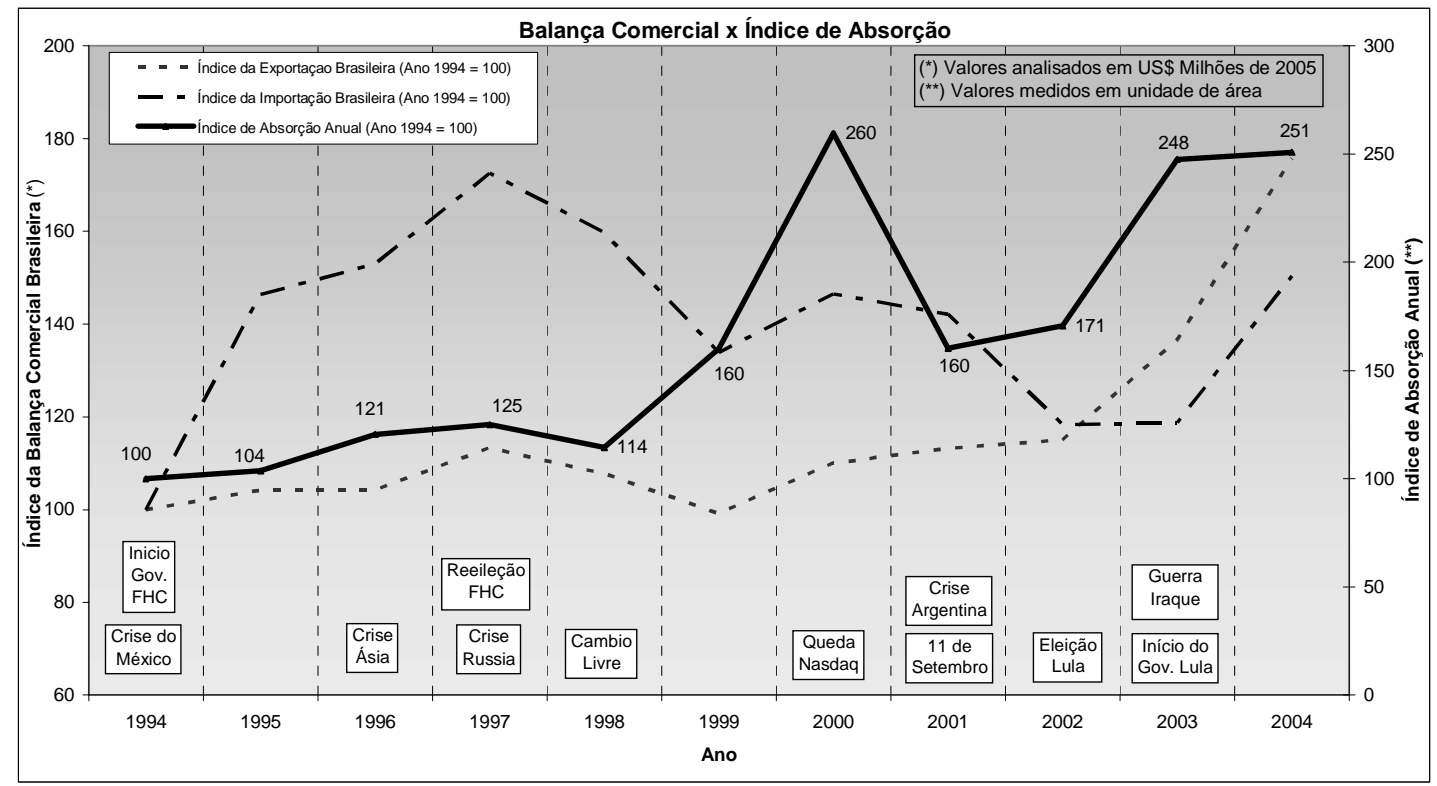


Percebe-se que, a partir de 2002, foi registrado um significativo aumento das exportações e, simultaneamente, um crescimento significativo da absorção de espaços de escritórios.

Ainda que o aumento da absorção registrada em 2003 não tenha sido caracterizado por expansões de empresas, podemos perceber uma maior confiança dos agentes tomadores de decisão das empresas ocupantes de espaços no mercado local, uma vez que as mesmas permitiram investimentos para suas relocalizações. Possivelmente o aumento das exportações desde 2002 tenha gerado esta maior confiança das empresas em média.

Figura 22: exportação brasileira x absorção de espaços de escritórios

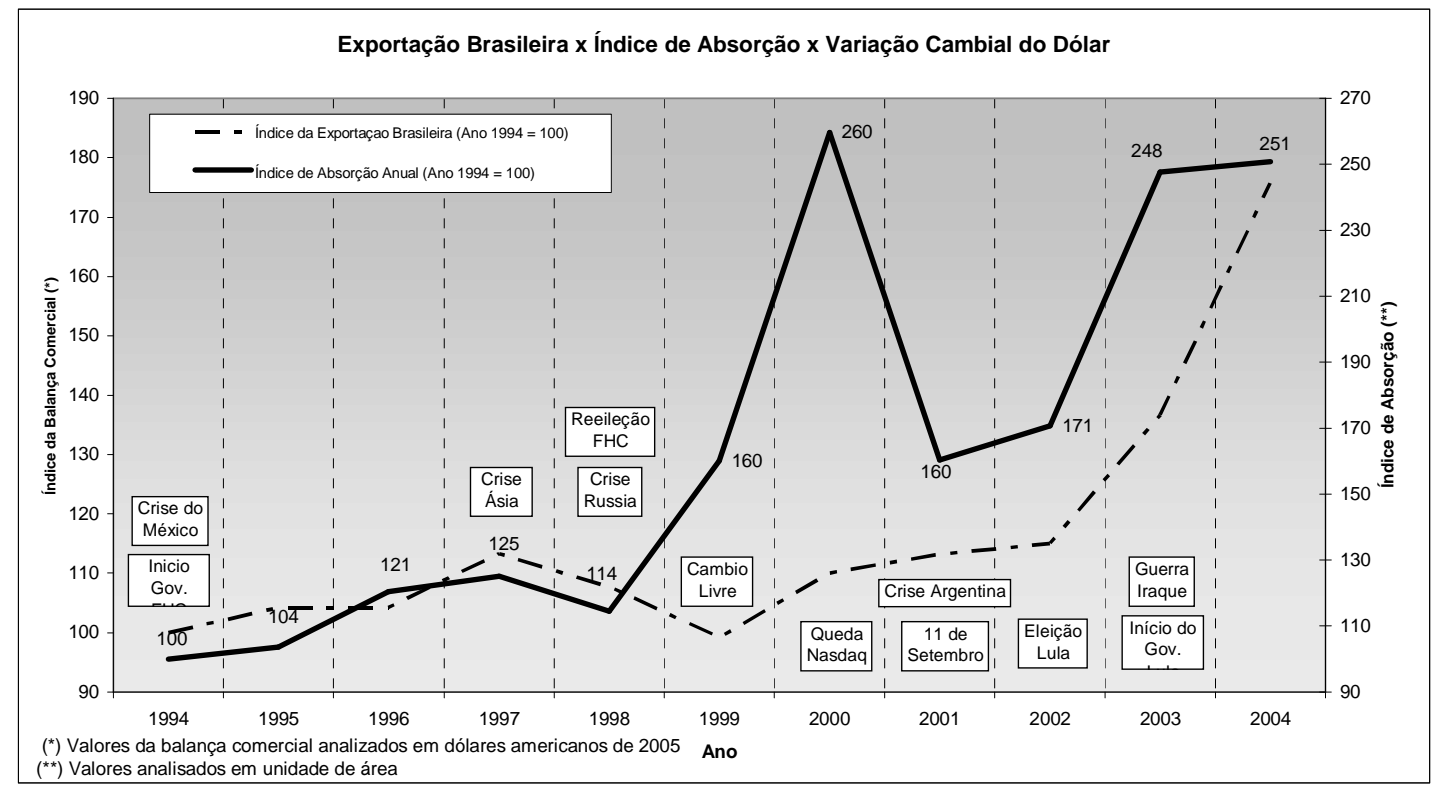

Conforme já mencionado, percebe-se a existência de uma significante semelhança de comportamento entre as séries de absorção de espaços de escritórios e da taxa de exportação entre 2001 e 2003, porém fica nítida a presença de outros fatores 
impactantes na demanda por edifícios de escritórios na cidade de São Paulo, tais como os mencionados no início deste capítulo.

É interessante perceber que, no período de 1998 a 2000, momento de significativas privatizações e de um expressivo volume de capital estrangeiro entrando no país, o câmbio do dólar e a absorção aumentou consideravelmente, enquanto as exportações permaneceram nos mesmos patamares.

Concluindo, sob um ponto de vista preliminar, podemos inferir que a relação de causa e efeito (tendo a taxa de exportação como causa e a absorção de espaços de escritórios na cidade de São Paulo como efeito) apresentou-se sobre o período ${ }^{28}$, com exceção dos anos entre 1998 e 2001.

Adicionalmente, vale perceber que o momento onde a taxa de exportação brasileira não se encontra com comportamento próximo à curva de absorção de espaços de escritórios é o de maior volatilidade desta, onde os investimentos diretos estrangeiros foram expressivos no Brasil e impactantes sobre o mercado de escritórios.

Desta forma, caso não houvesse ocorrido o volume expressivo de investimentos diretos estrangeiros no país entre 1998 e 2001, possivelmente o comportamento da curva do índice de absorção de escritórios seria menos volátil no período e, conseqüentemente, a semelhança de comportamento com a curva das exportações brasileiras seria possivelmente mais expressiva.

\footnotetext{
${ }^{28}$ A título complementar, vale comentar que o índice de correlação entre as curvas considerando todo o ciclo constitui-se em 0,68 .
} 
Portanto, tendo em vista o impacto das exportações sobre os setores industrial e comercial e a semelhança de comportamento das curvas acima, pode-se inferir a existência de uma relação positiva de causa e efeito entre as exportações brasileiras e o crescimento da demanda por espaços de escritórios no ciclo. 


\subsection{4) Taxa de Juros SELIC:}

Tendo em vista que a taxa de juros SELIC caracteriza o impacto do juros referencial da economia brasileira tanto na oferta (nos custos dos financiamentos e no custo de oportunidade) como na demanda (na capacidade da taxa de juros determinar em certo grau o aquecimento ou desaquecimento do investimento e demanda agregada), tentamos identificar possíveis influências da variação desta taxa no volume de absorção de espaços de escritórios na cidade de São Paulo.

Jaco (entrevista) comentou: “...entendo ser este índice o indicador mais representativo sobre o mercado de escritórios, tanto para ocupação de novas áreas, que caracteriza expansão, ou seja, o crescimento do país, como para novos investimentos, os quais movimentam a demanda reprimida."

Sartori (entrevista) acredita que a taxa de juros SELIC influencie diretamente a absorção de espaços de escritórios. Entretanto, ressalta que os resultados aparecem somente após 6 a 12 meses das as alterações da taxa em questão. Tal período se deve ao tempo necessário para a ocorrência de todo o processo até a absorção de um espaço por uma empresa, desde a percepção de variação da taxa de juros pelos agentes decisores das empresas ocupantes de espaço, análise do impacto da mesma, dentre outros fatores, na sua atividade de negócio, decisão pela relocalização e pesquisa de alternativas no mercado imobiliário, negociação e conclusão de uma nova transação.

Miranda (entrevista) acrescenta que “... a taxa de juros referencial SELIC é um instrumento político-econômico, o qual dirige a percepção dos empresários e orienta 
os investimentos para os setores industrial, comercial e serviços. Esta taxa tem forte relação com a demanda de escritórios em médio prazo. Preliminarmente, quanto mais baixa a taxa de juros referencial, maior a confiança do mercado no desenvolvimento econômico, o que motiva os ocupantes a demandar por mais espaço”.

Figura 24: taxa de juros SELIC x índice de absorção de espaços de escritórios na cidade de São Paulo

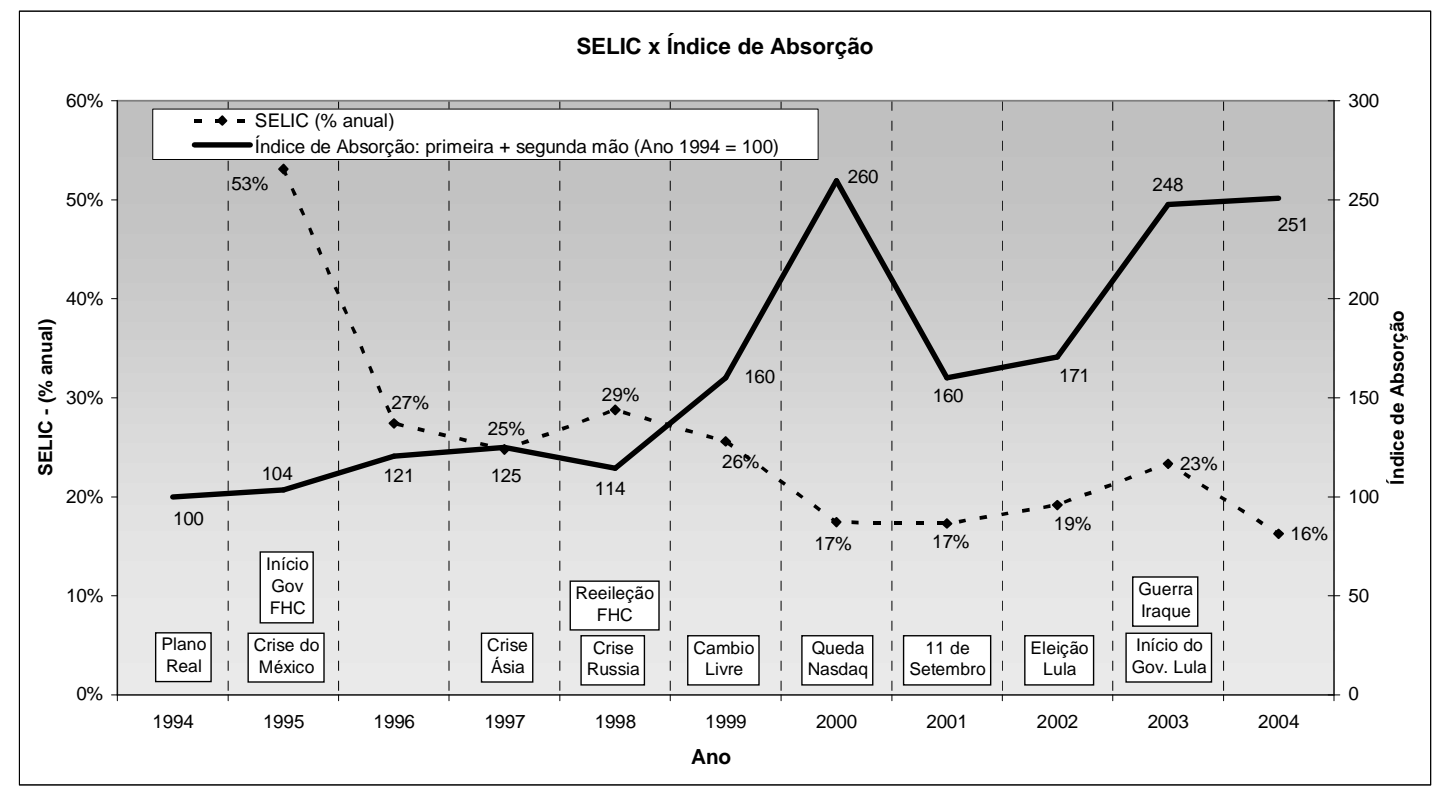

Percebe-se um comportamento inverso entre as variações na absorção de escritórios e a taxa de juros SELIC. Uma possível explicação para tal é o fato da absorção de espaços de escritório acontecer após um aquecimento na economia (quando as empresas expandem e demandam por novos espaços), enquanto um aumento na taxa de juros SELIC se configura como uma manobra político-econômica usual brasileira para atrair novos investimentos externos ao país após sofrer (ou prever) um potencial desaquecimento da economia local. 
Tendo em vista que a taxa de juros referencial SELIC é um instrumento políticoeconômico, o qual dirige a percepção dos tomadores de decisão das empresas ocupantes de espaço e orienta os investimentos para os setores industrial, comercial e de serviços. Esta taxa tem potencial relação com a demanda de escritórios em médio prazo e, portanto, a percepção do incorporador e do investidor imobiliário deve incluir a análise da política monetária brasileira no momento da decisão pelo investimento, com o intuito de identificar a tendência deste indicador em um horizonte de médio prazo e, com isso, possuir um parâmetro adicional para prever a demanda no momento de entrega do edifício (final da construção). 


\subsection{5) Inflação brasileira:}

Dentre os efeitos significativos do processo inflacionário mencionados por Vasconcelos e Garcia (2000), vale destacar neste momento o efeito que altas taxas de inflação provocam sobre as expectativas de coletividade, ou seja, quanto ao futuro quadro econômico.

Conforme mencionado no capítulo 3, o setor empresarial é sensível à influência da inflação quando se abordam as expectativas sobre o futuro, dada a instabilidade e a imprevisibilidade de seus lucros.

Assim, parte-se da hipótese de que a oscilação da inflação brasileira gera um ambiente de incerteza para as previsões dos agentes tomadores de decisão das empresas ocupantes de espaço, obrigando-os, em diversos casos, a assumirem um maior patamar de risco ou a aplicar maiores coeficientes de segurança nas margens de lucro de suas novas unidades de negócio.

Miranda (entrevista) afirma que, “... em linhas gerais, enquanto a taxa de juros direciona a percepção de risco, a inflação é o resultado real da política econômica adotada. Combinadamente estes dois elementos são instrumentos dos empresários dos setores que determinam seus planos de expansão e contração operacional que determinam a demanda por escritórios. O comportamento da inflação vai influenciar mais as empresas orientadas ao consumo, assim os setores comercial e industrial tem maior vulnerabilidade a esse índice". 
Desta forma, vale verificar se é possível identificar, por séries históricas, alguma influência negativa da variação da inflação no volume de absorção de espaços de escritórios na cidade de São Paulo.

O ciclo de estudo do presente trabalho compreende somente o período pós Plano Real. Assim, não será possível analisar o períodos anteriores, que se caracterizaram por "super-inflação".

Para efeito de análise, adotamos o índice IGP-DI ${ }^{29}$ como o representante do comportamento da inflação no Brasil.

Figura 25: Variação do índice inflacionário IGP-DI x Absorção de espaços de escritórios na cidade de São Paulo

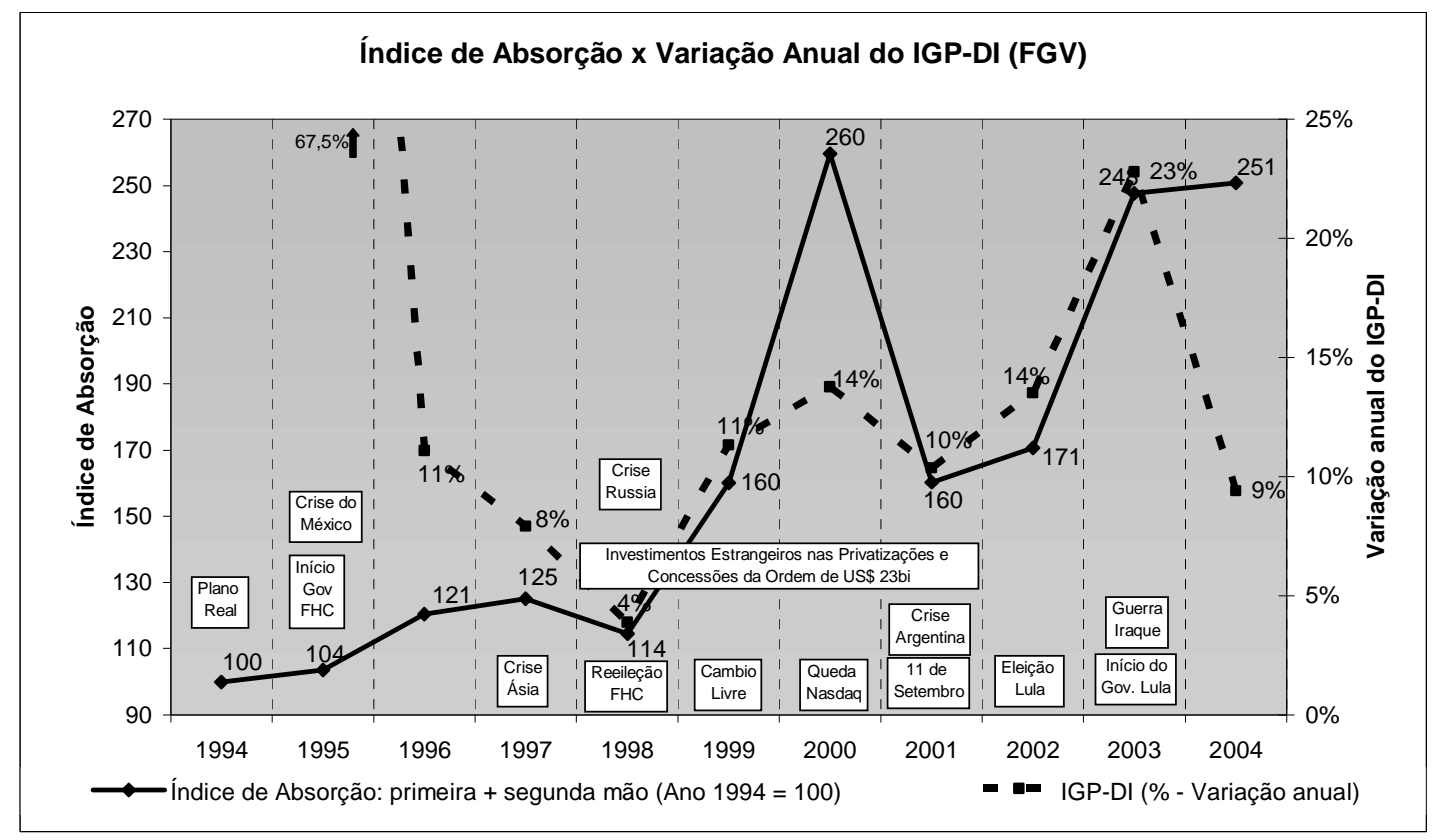

${ }^{29}$ A explicação da representatividade deste índice encontra-se descrita no capítulo 3. 
Observando o gráfico, percebe-se uma semelhança de comportamento positiva entre as curvas representadas entre 1997 e 2003, porém tal fato não pôde ser respaldado por uma justificativa plausível de relação de causa e efeito.

Adicionalmente, vale comentar que, entre 2001 e 2003, quando (i) alguns índices inflacionários que eram aplicados aos contratos de locação (tais como IGP-DI e IGPM/FGV, por exemplo) aumentaram expressivamente, e, por outro lado, (ii) os valores transacionados em novas locações atravessavam uma fase de declínio expressivo, diversas empresas não aplicaram os reajustes previstos em seus contratos de locação, entretanto renegociaram os seus respectivos valores de aluguel. Tal fato gera uma distorção na análise do gráfico no período.

Concluindo, não foi possível identificar semelhanças negativas de comportamento ou relações de causa e efeito plausíveis de comentários entre os indicadores IGP-DI e o índice de absorção no período de 1994 a 2004. Desta forma, não foi possível, com os dados acima, defender a hipótese supra mencionada, onde a oscilação da inflação brasileira geraria um ambiente de incerteza para as previsões dos agentes tomadores de decisão das empresas ocupantes de espaço, de forma a influenciar a absorção de espaços de escritórios na cidade de São Paulo.

Possivelmente, tendo em vista que o ciclo analisado iniciou após o plano Real, o mesmo apresenta um cenário de inflação controlada e, portanto, as variações dos índices inflacionários não são suficientemente significativas a ponto de constituírem fatores importantes na matriz de tomada de decisão das empresas ocupantes de espaço. 


\section{2) A OFERTA}

A análise da oferta do novo estoque de escritórios será parcialmente desenvolvida partindo-se do referencial teórico do capítulo 2, o qual permite explicar as oscilações da oferta pelos "choques" que impactam no estado de confiança dos agentes na economia, como também pelos fatores estruturais, relacionados ao fato de implantação e operação serem realizadas por distintos agentes, e conseqüentemente, com distintos objetivos, lógicas e expectativas.

Devemos destacar que no caso do setor de EEL, a defasagem entre a decisão e a inserção do empreendimento no mercado resulta em um fenômeno estrutural de comportamento.

Assim, nas análises das oscilações da oferta de EEL, consideraremos como uma premissa que os "choques", determinantes do estado de confiança dos empreendedores e conseqüentemente das suas decisões, explicam as flutuações da oferta em conjunto com as características estruturais do setor, potencializando a volatilidade da oferta.

Ainda com relação às premissas, como a oferta de novo estoque dos EEL ocorre com defasagem no tempo em relação às decisões dos empreendedores, adotaremos um período entre a decisão de investir e a oferta do empreendimento no mercado de locação.

Sartori (entrevista), por ter acompanhado o desenvolvimento de uma quantidade expressiva de empreendimentos do mercado de São Paulo, desde a fase formatação, elaboração até a respectiva comercialização, mencionou acreditar que o período 
médio entre a tomada de decisão pela construção de um novo empreendimento e a efetiva entrega do edifício ao mercado é de aproximadamente 3 a 3,5 anos para edifícios de grande porte e de 2,5 a 3 anos para edifícios de menor porte.

Adicionalmente, citando como exemplo os edifícios Faria Lima Financial Center, Birmann 29, CENU Torre Norte, Faria Lima Square e CYK, Sartori mencionou que, sob um ponto de vista macro, este período é usualmente compreendido pelas seguintes fases: (i) compra do terreno e estudos de viabilidade, (ii) estudos preliminares de implantação,(iii) definição do tamanho de laje, "core", padrão de edifício e público alvo, (iv) projetos (arquitetura e complementares), aprovações e (v) construção.

Segundo o estudo de Sivitanides e Sivitanidou (2000), este período é de aproximadamente 3,5 anos em um momento pré-recessão e passa a ser de aproximadamente 2,1 anos em um período pós recessão (vide capítulo 2).

Desta forma, tendo em vista a percepção sobre o mercado paulistano relatada por Sartori (entrevista) e os estudos de Sivitanides e Sivitanidou (2000), adotaremos para esta pesquisa um período entre a decisão de investir e a oferta do empreendimento no mercado de locação entre 2 e 3 anos.

Vale o comentário de Miranda (entrevista) referente ao perfil deste investimento imobiliário, considerando o período de 2 a 3 anos como somente parte do ciclo para a obtenção dos retornos desejados no setor: "a partir do pressuposto de que o cenário é favorável para investimento e exista a predisposição ao risco e capital, os incorporadores e investidores levarão esse período de 2 a 3 anos somente para o desenvolvimento do produto, o que torna este investimento imobiliário típico para 
longo prazo, com risco mais mitigado e menos volátil ... conseqüentemente, sendo produtos de longo prazo, há maior dependência dos agentes econômicos para o melhor retorno, ou até mesmo para garantir o retorno inicialmente desenhado".

O gráfico abaixo ilustra tanto o movimento anual do novo estoque sem defasagem de tempo, ou seja, no momento em que entraram no mercado (o momento de entrada de um edifício no mercado é caracterizado pela retirada do documento Habite-se), como também ilustra o movimento do novo estoque e sua variação anual com defasagem de dois e três anos (defasagem ou período de maturação), realizada no novo estoque com o intuito de registrar o momento da decisão pelo investimento nos novos edifícios.

Figura 26: Representa o novo estoque contabilizado em áreas

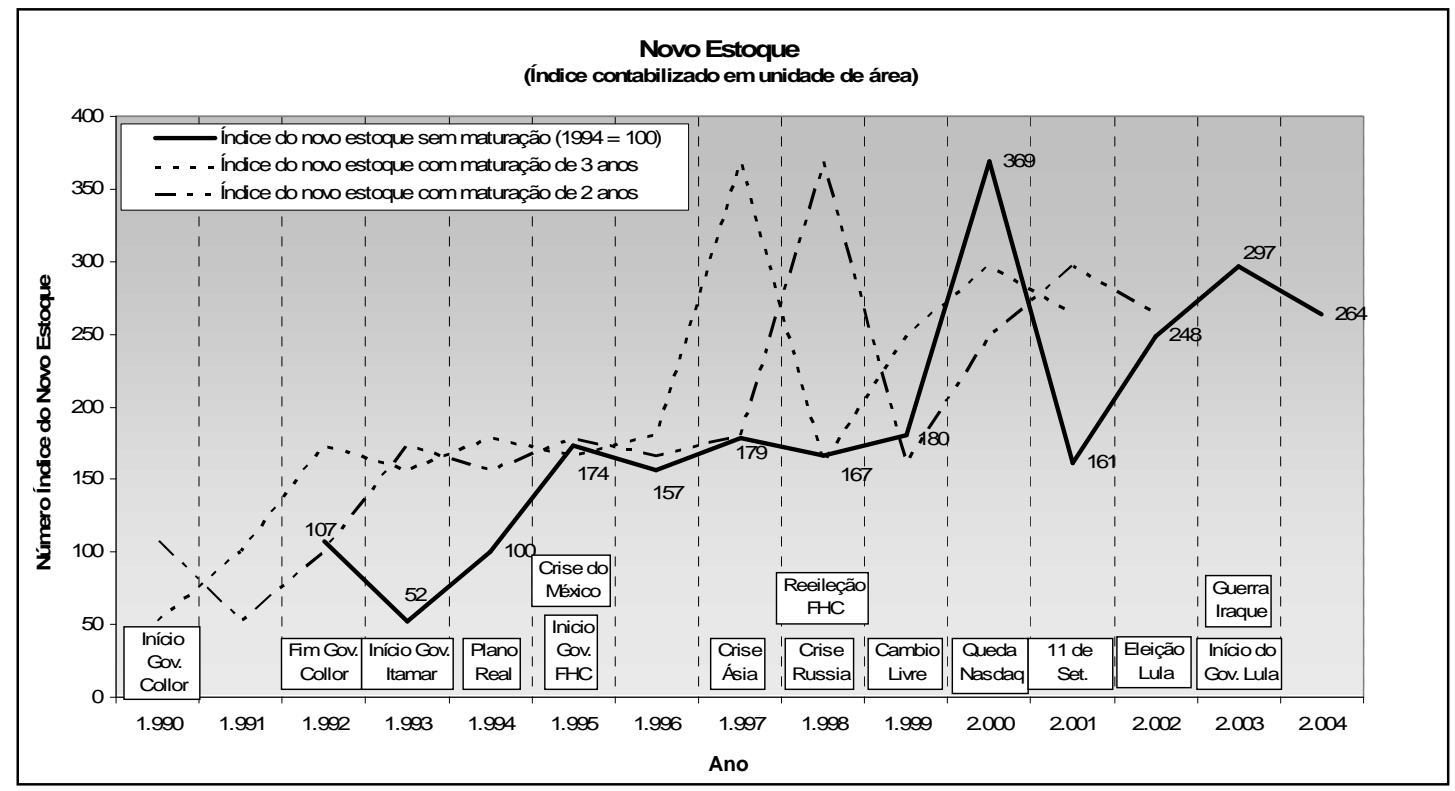

O volume de novo estoque apresentou um crescimento de 3,3 vezes de 1993 e 1995 , manteve-se aproximadamente constante até 1999, porém o mercado de escritórios de São Paulo encontrou o seu recorde de entrega de novos edifícios em 2000, quando 
apresentou um crescimento acima de 7 vezes a apresentada no ano de início do ciclo de estudo (1993).

Após um período de redução no volume de entregas em 2001, o índice em questão voltou a apresentar aumento em 2002 e 2003, porém retornando a demonstrar reduções em 2004, último ano do ciclo em estudo.

Com o intuito de explicar as possíveis causas para este comportamento, vamos inicialmente analisar o impacto dos "choques" no estado de confiança dos agentes empreendedores do mercado de escritórios, por meio da confrontação entre as variações anuais negativas do novo estoque e os fatos ou "choques" do sistema, com defasagem de dois e três anos.

Posteriormente, analisaremos o comportamento da variação anual do novo estoque em relação ao PIB, à taxa de vacância e ao IBOVESPA, para compreendermos melhor a natureza dos determinantes do investimento dos empreendedores de edifícios de escritórios na cidade de São Paulo.

Em função da defasagem entre a decisão e a conclusão da implantação do empreendimento, iniciaremos a descrição dos choques a partir de 1990, ano do Plano Collor, o qual poderia explicar uma variação negativa de aproximadamente $52 \%$ no novo estoque, ocorrida em 1993.

Sartori (entrevista) teceu as seguintes considerações com relação ao período do ciclo de 1992 a 1994:

"Foi um período de crise no mercado de locação visto que após o plano Collor, em 1990, os incorporadores pararam de produzir, fato que resultou na diminuição do novo estoque no início do período mencionado, somente sendo retomado no final do 
governo Collor, o que refletiu no aumento do novo estoque entre 93 e 94 . Devido a falta de liquidez na economia, a vacância e oferta aumentaram no mesmo período."

Adicionalmente, com relação ao plano Real, Sartori (entrevista) comentou: "O Plano Real, em 1994, foi um “divisor de águas” no mercado de escritórios. A estabilização da economia e a conseqüente entrada de empresas estrangeiras no país foi o principal motivo para os incorporadores "apostarem" no crescimento do mercado e lançarem novos empreendimentos. $\mathrm{O}$ que vimos desde então foram crises internacionais que afetaram o crescimento do país e conseqüentemente o mercado de escritórios, mas em geral, a partir de 1994 o volume do mercado mudou."

Em 1996 e em 1998, ocorreram duas pouco expressivas novas variações negativas, de aproximadamente $10 \%$ e $7 \%$ respectivamente, as quais poderiam estar relacionadas às incertezas decorrentes do início do Governo Itamar Franco em 1993, ao início do Plano Real e ao ano eleitoral em 1994, como também à Crise do México em 1995.

Seguindo a mesma linha de raciocínio, a variação negativa de aproximadamente 56\% ocorrida no ano 2001, estaria relacionada à Crise da Ásia em 1997, como também a Crise da Rússia e ano eleitoral em 1998, porém aqui vale ressaltar um outro fenômeno, ou seja, o estouro da bolha da NASDAQ em 2000, o atentado ao World Trade Center em 11 de setembro de 2001 e a crise da Argentina foram motivadores da desaceleração econômica seguinte, a qual gerou um movimento conjunto de diversos incorporadores no sentido de atrasar a entrega das obras que estavam em andamento. $\mathrm{O}$ andamento de diversas obras foi interrompido em 2001 e, aquelas 
construções que não puderam ser interrompidas foram atrasadas, com o intuito de posicionar a sua entrega ao mercado em um momento de recuperação da economia.

Grande parte das obras postergadas em 2001 vieram a ser entregues nos anos de 2002 e 2003, gerando, respectivamente, aumentos no volume de entrega de $54 \%$ e $20 \%$ com relação aos anos anteriores.

A variação negativa de aproximadamente 36\% encontrada em 2004 se justificaria pela hipótese de que (i) grande parte das obras em andamento que tiveram suas datas de entrega postergadas já haviam sido concluídas nos anos anteriores e de que (ii) tendo em vista a crise sofrida no setor nos anos anteriores, diversos investidores e incorporadores entendiam ser demasiadamente alto o patamar de risco envolvido neste setor e, desta forma, poucas foram as obras dos projetos aprovados na prefeitura da cidade que iniciaram no período em questão.

Jaco (entrevista) ressalta ter sido notória a ausência de profissionalismo (ou amadorismo) do mercado imobiliário da cidade de São Paulo neste ciclo, uma vez que:

(i) uma quantidade significativa de incorporadores, em atitude oportunista, se capitalizou para a construção de novos empreendimentos através da venda de parcelas dos mesmos a investidores ${ }^{30}$, transferindo o risco do negócio a estes compradores e permanecendo sem um representativo comprometimento com o resultado final do EEL, isto é, conforme as palavras de Jaco, diversos incorporadores atuaram como prestadores de serviço a procura de honorários, enquanto investidores

\footnotetext{
${ }^{30}$ Segundo Jaco (entrevista), estes investidores foram, em sua maioria, pessoas físicas com pouco conhecimento do mercado imobiliário.
} 
inexperientes se envolveram comprando conjuntos ou andares de edifícios construídos em co-incorporação ${ }^{31}$, assumindo expressiva parcela de risco do negócio e sem possuir conhecimento do mercado em questão, bem como sem ter a comprovação exata dos custos e investimentos realizados (ou a serem realizados) pelo incorporador, tal como o valor envolvido na compra do terreno, por exemplo;

(ii) motivados em grande parte pela estrutura de captação de recursos descrita acima, em 1999 e 2000, o mercado imobiliário entrou em euforia e diversas obras para novos produtos foram iniciadas sem a realização de um planejamento consistente.

Esta última evidência apontada por Jaco no mercado imobiliário de São Paulo se encontra alinhada com a justificativa de Rocha Lima (em aula) para a expressiva volatilidade do novo estoque em relação à demanda mencionada no capítulo 1 da presente pesquisa, ou seja, um "inconsciente coletivo" de diversos agentes de um mesmo setor (neste caso de investidores e incorporadores), devido à falta de informações, faz com que diversos agentes tomem a iniciativa para investir baseados no sucesso de empreendimentos já existentes, ao invés de se basear em estudos de comportamento de mercado.

Miranda (entrevista) acrescenta: “é prudente não concluir que apenas os fatores macro-economicos foram os agentes que causaram a interrupção ou atraso da entrega dos novos estoques de escritório em São Paulo entre 2001 e 2004. Fatores locais

\footnotetext{
${ }^{31}$ Entende-se, neste caso, por co-incorporação a estrutura de captação de recursos para EEL onde os investidores compram conjuntos ou andares do empreendimento (em projeto ou em fase de construção) e, desta forma, assumem o risco do negócio como co-incorporadores. Martin Jaco adicionou ainda que, durante o ciclo em estudo, diversos incorporadores tinham dificuldade para capitação dos recursos necessários para a estruturação financeira do empreendimento e, através de coincorporações, desenvolveriam, sem a realização das necessárias análises de necessidade do mercado, o maior número de empreendimentos que fosse possível.
} 
como a elevação dos preços dos CEPAC's (certificado de potencial adicional de construção) para as operações urbanas consorciadas, resultaram no "arquivamento" de aproximadamente 12 projetos na nova Av. Faria Lima. Há também o fenômeno do excesso de oferta que ao tornar os valores de novas locações muito baixos, em comparação ao projetado no início das obras, e além disso a longa absorção ${ }^{32}$, afastaram momentaneamente os interesses de vários incorporadores para novos EEL."

O fato da expressiva diminuição da área de escritório entregue ao mercado logo após 2000 ter sido motivada expressivamente pelos acontecimentos deste ano, irá inserir um certo cuidado na forma de analisar os gráficos nos anos subsequentes a 2000, uma vez que, sob um ponto de vista preliminar, podemos inferir que, antes do ano 2000, quando deslocávamos a curva do novo estoque em dois ou três anos para trás, encontrávamos o momento da tomada de decisão do investidor / incorporador. Porém, partindo do princípio de que em 2001 e 2002 (este último ano em menor escala), diversas construções que se encontravam em andamento foram atrasadas, resultando em entregas posteriores, entendemos que, em média, os prazos das construções entregues em 2003 e 2004 (este último em menor escala) aumentaram com relação aos anos anteriores.

Tendo em vista o descrito acima e com o intuito de compreendermos melhor a natureza dos determinantes do investimento dos empreendedores de EEL na cidade de São Paulo, analisaremos o comportamento da variação anual do novo estoque em relação ao PIB, à taxa de vacância e ao IBOVESPA.

\footnotetext{
${ }^{32}$ Ao mencionar "longa absorção", Miranda se referia à baixa velocidade de locação dos empreendimentos lançados ao mercado.
} 
6.2.1) O Novo Estoque e o Produto Interno Bruto (PIB) brasileiro:

Para obtermos uma maior sensibilidade na análise do Produto Interno Bruto (PIB), adotamos o estudo da variação anual deste indicador.

Segundo Sartori (entrevista), o PIB consiste em um indicador com impacto de longo prazo e indireto sobre o mercado imobiliário, ou seja, o PIB precisa apresentar uma taxa de crescimento pouco volátil por anos consecutivos para influenciar significantemente as decisões dos incorporadores no longo prazo. Como o reflexo da decisão pela incorporação leva alguns anos para ser medido, existe a possibilidade do PIB sofrer variações expressivas neste período. Por este motivo, Sartori acredita não ser possível citar exemplos diretos de relação entre o PIB e uma decisão de incorporação por novos empreendimentos, todavia, Sartori entende que todo incorporador considera indiretamente esta informação.

Figura 27: Novo estoque com período de maturação de 2 anos e variação anual

\section{do PIB}

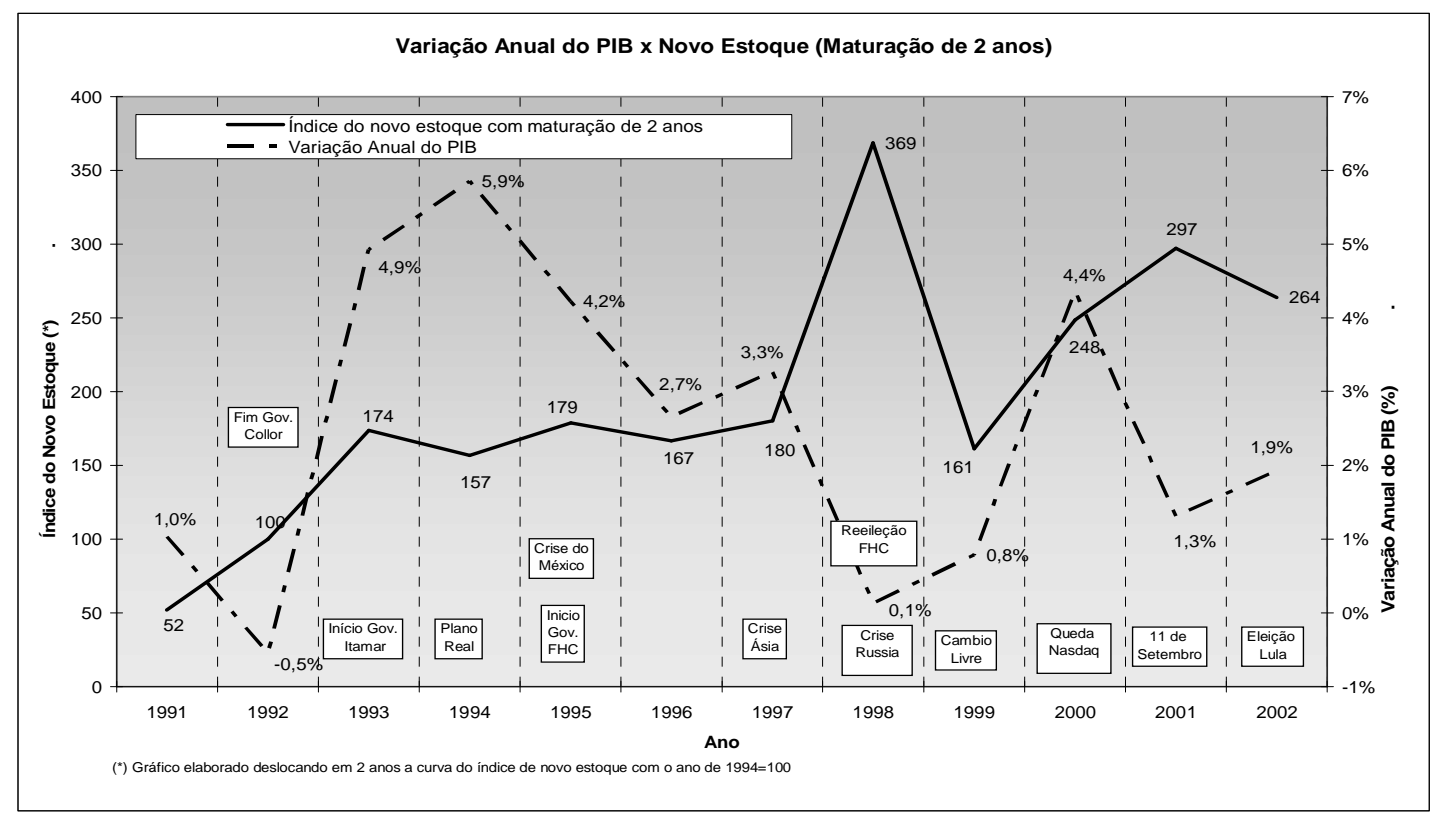


Figura 28: Novo estoque com período de maturação de 3 anos e variação anual do PIB

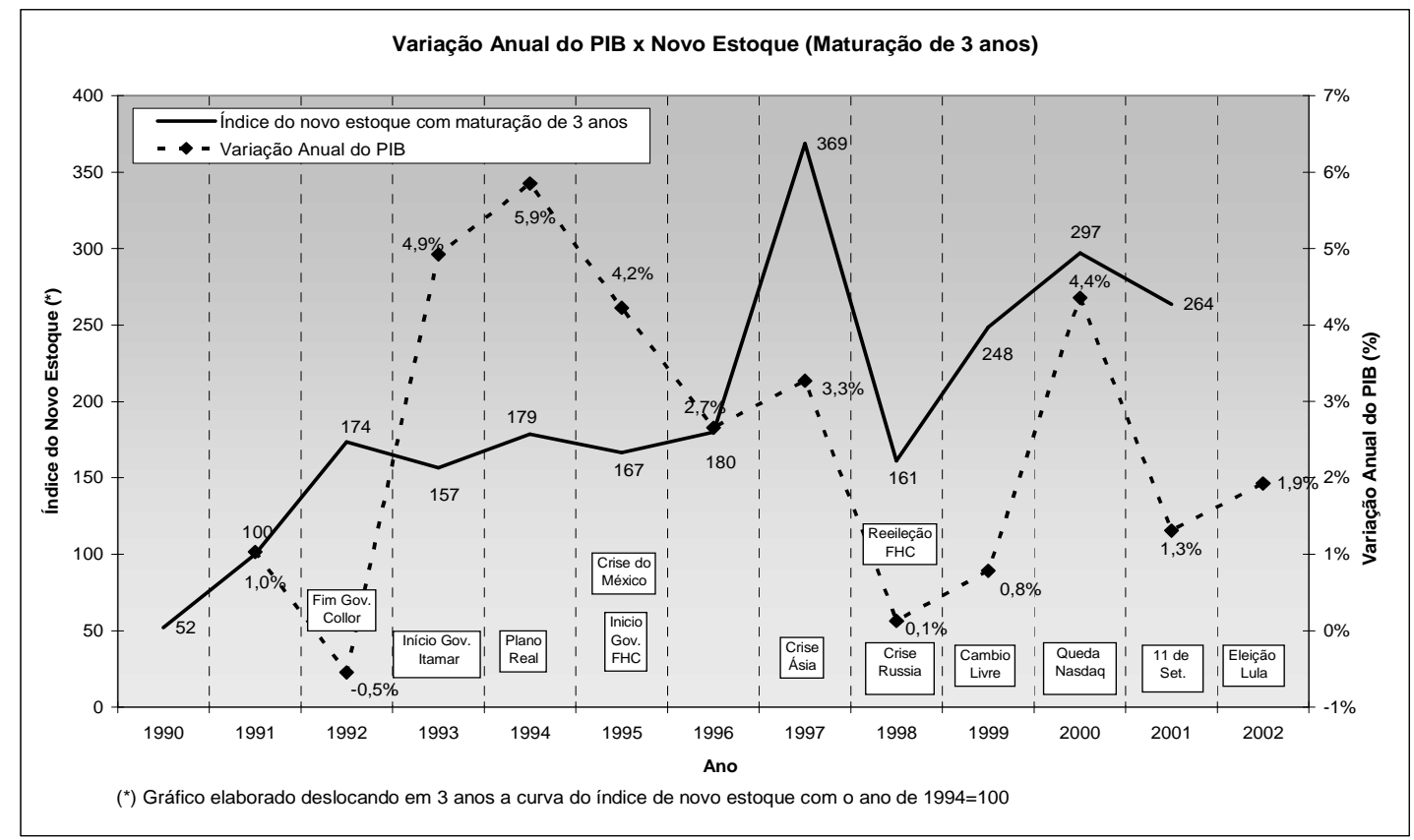

Analisando os gráficos quanto à relação entre o novo estoque de edifícios de escritórios na cidade de São Paulo e a variação anual do PIB brasileiro, podemos observar, em todo o período em análise e adotando-se a defasagem tanto de dois quanto de três anos, uma semelhança de comportamento somente parcial, ou seja, por determinados períodos do ciclo.

Observando especificamente o período de 1997 a 2002 no gráfico de dois anos de maturação, percebemos comportamentos inversos das curvas. Por outro lado, ao analisarmos os períodos de 1996 a 2001 no gráfico com três anos de maturação, percebemos comportamentos próximos entre as curvas.

Desta forma, como uma relação inversa entre a variação do PIB e o volume de entrega de novo estoque de edifícios não pode ser embasada por alguma explicação 
plausível, prosseguimos as análises desta relação com o período de maturação de três anos.

Assim, observando o gráfico referente a três anos de maturação, inferimos que, devido à instabilidade política e econômica do final dos anos 80 e início da década de 90, os incorporadores e investidores, mesmo observando um notório aumento no PIB em 1993 (4,92\% acima de 1992), ainda permaneceram aparentemente inseguros com a hipótese de investir em edifícios de escritórios na cidade de São Paulo, mantendo o gráfico de momento da decisão do novo estoque (com maturação de três anos) aproximadamente constante até o ano de 1997, quando diversos investidores e incorporadores decidiram entrar em incorporações de novos edifícios de escritórios na cidade, que vieram culminar em uma entrega recorde em 2000 (7,1 vezes superior à entrega encontrada no ano de 1993).

Embora após 1997, o comportamento do PIB e do gráfico de novo estoque (com período de maturação de três anos) tenham apresentado comportamentos aproximadamente similares, não foi possível inferir possíveis relações de causa e efeito, uma vez que, conforme comentado acima, o comportamento do novo estoque neste período esteve intimamente atrelado aos acontecimentos econômicos de 2000 e 2001. 
6.2.2) O Novo Estoque e a Taxa de Vacância em edifícios de escritórios na cidade de

\section{$\underline{\text { São Paulo }}$}

Adicionalmente, com o intuito de perceber se os incorporadores utilizam-se do indicador "taxa de vacância" na decisão de iniciar novos empreendimentos, verificamos o comportamento do novo estoque (com defasagem de dois a três anos) em relação à taxa de vacância.

Miranda (entrevista) afirma ser relevante ao incorporador e ao investidor o conhecimento da previsão da taxa de vacância no momento do lançamento do empreendimento ao mercado.

Sartori (entrevista) entende que a taxa de vacância se constitui em um "estímulo" para conduzir o incorporador a uma decisão, a qual somente será concretizada após a análise cruzada da oferta futura de espaços de escritórios, da projeção de novo estoque futuro e projeção de absorção futura de espaços de escritório.

Jaco (entrevista) complementa que a taxa de vacância exerce significativo impacto na estruturação financeira do empreendimento, uma vez que altera os valores de terreno $^{33}$ na região em estudo e, desta forma pode comprometer os resultados futuros.

Pelos gráficos abaixo, embora com maior constância da curva de taxa de vacância, percebe-se um comportamento inverso entre as curvas de taxa de vacância e de novo

\footnotetext{
${ }^{33}$ Quanto menor a taxa de vacância em uma determinada região, maior será a tendência de elevação nos valores de terrenos.
} 
estoque, principalmente quando se considerou uma defasagem ou maturação de 2 $\operatorname{anos}^{34}$.

Figura 29: Taxa de vacância e novo estoque de espaços de escritórios em São

\section{Paulo com maturação de 2 e 3 anos}

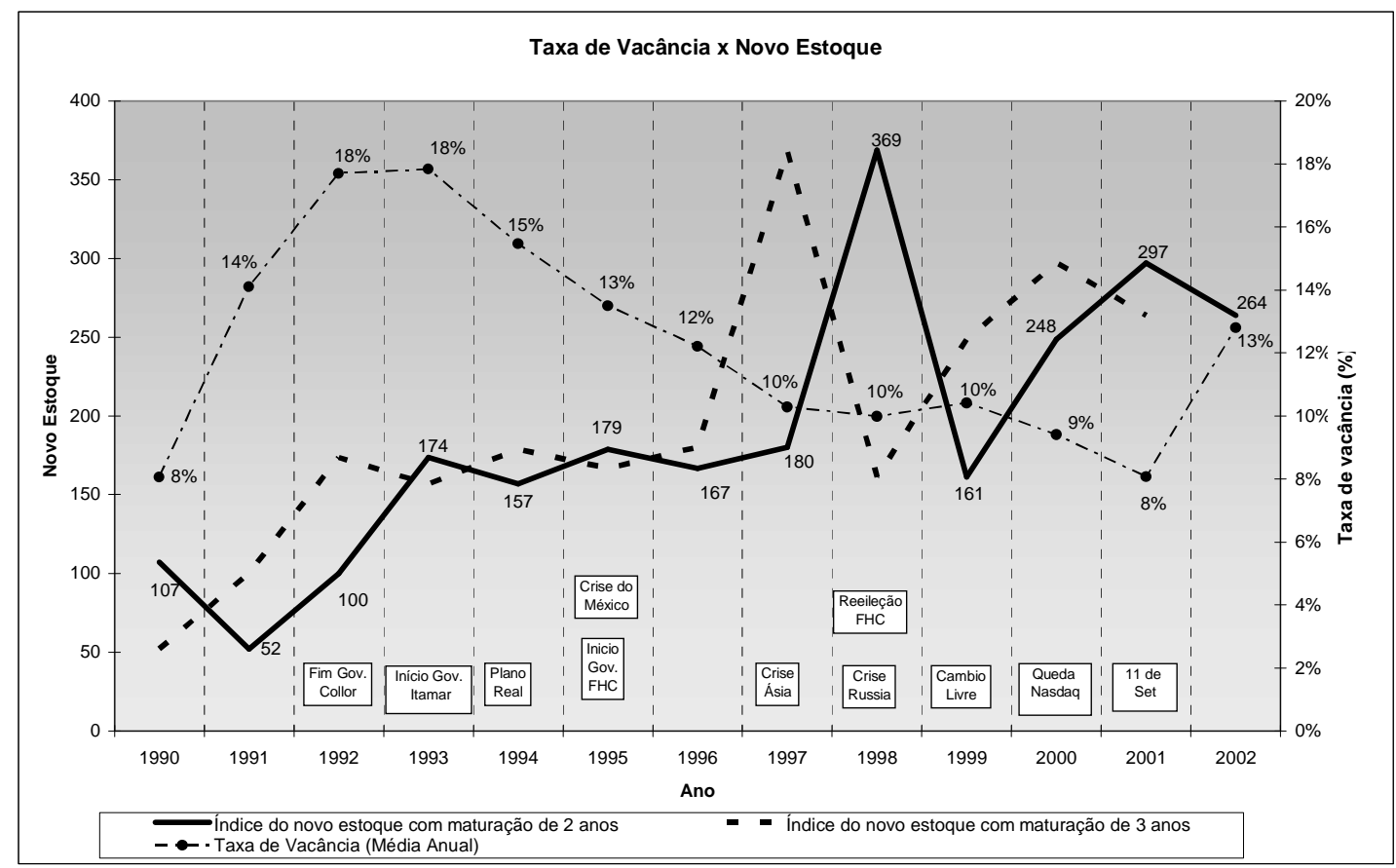

A expressiva queda na taxa de vacância até 1997 e 1998 levaram os incorporadores a uma coletiva decisão por investimento em novos empreendimentos em 1998, que foram concluídos por volta do ano 2000 e 2001, surpreendidos então pela desaceleração da economia deste ano. Fato este que elevou consideravelmente a taxa de vacância da cidade a partir desta data.

Desta forma, observando do gráfico, é possível inferir que, em média, os investidores utilizam-se do indicador taxa de vacância no processo de decisão por novos

\footnotetext{
${ }^{34}$ Desde 1991 a 2002, a correlação encontrada entre a taxa de vacância e o novo estoque com período de maturação de 2 anos foi de $-62 \%$, enquanto que, quando consideramos um período de maturação de 3 anos, encontramos uma correlação de $-28 \%$ entre 1990 e 2001.
} 
empreendimentos e que, neste período estudado, o período entre a decisão do novo investimento e a retirada do Habite-se do imóvel foi aproximadamente de dois anos.

Entretanto, é interessante perceber que, embora exista a semelhança de comportamento no ciclo, o comportamento volátil da curva de decisão pelo investimento em empreendimentos de escritórios (curva de novo estoque com 2 anos de maturação) nos anos de 1998 e 1999 foi intimamente atrelado aos acontecimentos econômicos de 2000 e 2001 supramencionados e, portanto, não foi possível inferir possíveis relações de causa e efeito entre as curvas do gráfico neste período.

Concluindo, a oferta de novo estoque de escritórios pelos empreendedores imobiliários da cidade de São Paulo esteve conforme observamos na teoria apresentada no capítulo 2, relacionada à demanda. O comportamento com variações acentuadas da taxa de vacância, entretanto, seria justificado pela característica estrutural do setor de não linearidade da produção, como também aos "choques", tanto externos quanto internos.

Sartori (entrevista) critica tal comportamento do mercado, mencionando que a análise do novo estoque e da oferta concorrente futura de edifícios de escritórios (realizando um tratamento por tamanho de laje, qualidade e localização do novo estoque) são informações mais seguras que a taxa de vacância para embasar uma tomada de decisão, devido à sua menor volatilidade, uma vez que usualmente levam, no mínimo, dois a três anos para configurar alguma alteração de cenário.

Complementando, vale ressaltar o risco envolvido na tomada de decisão (pelo investimento em novos empreendimentos) baseada na taxa de vacância do setor, uma 
vez que se trata de um indicador com razoável grau de volatilidade e que não mede expectativas e previsões futuras do mercado.

Em outras palavras, tendo em vista que empreendimentos de EEL demandam um período entre a decisão pelo investimento e o início do fluxo de receitas ${ }^{35}$, é aconselhável a análise de outros indicadores, tais como volume de novo estoque futuro e de previsão de oferta concorrente futura (realizando um tratamento por tamanho de laje, qualidade e localização do novo estoque), conforme mencionado por Sartori (entrevista).

Assim, a hipótese do comportamento médio do mercado vincular a decisão pelo investimento em EEL à análise pontual da taxa de vacância demonstra um determinado grau de amadorismo do mercado, uma vez que permite-nos concluir que uma expressiva parcela dos investimentos no setor estão sendo realizados baseados no sucesso de empreendimentos já existentes, ao invés de se basearem em estudos de comportamento do mercado futuro, o que caracteriza a prática do "inconsciente coletivo", mencionado por Rocha Lima em aula e abordada no capítulo 1 da presente pesquisa.

\footnotetext{
${ }^{35}$ Vide Pritchett (1984) e Sivitanides e Sivitanidou (2000).
} 
6.2.3) O Novo Estoque em edifícios de escritórios na cidade de São Paulo e a Variação anual do IBOVESPA

Será verificado agora, através de gráfico, o comportamento dessa volatilidade da oferta de novo estoque de escritórios pelos empreendedores vis-a-vis o IBOVESPA. Essa comparação tem o objetivo de analisar a volatilidade de um investimento, entendido pela maior parte de seus investidores como seguro e estável, em relação a outro investimento reconhecido como de maior risco e volatilidade.

Figura 30 - IBOVESPA e novo estoque de espaços de escritórios em São Paulo.

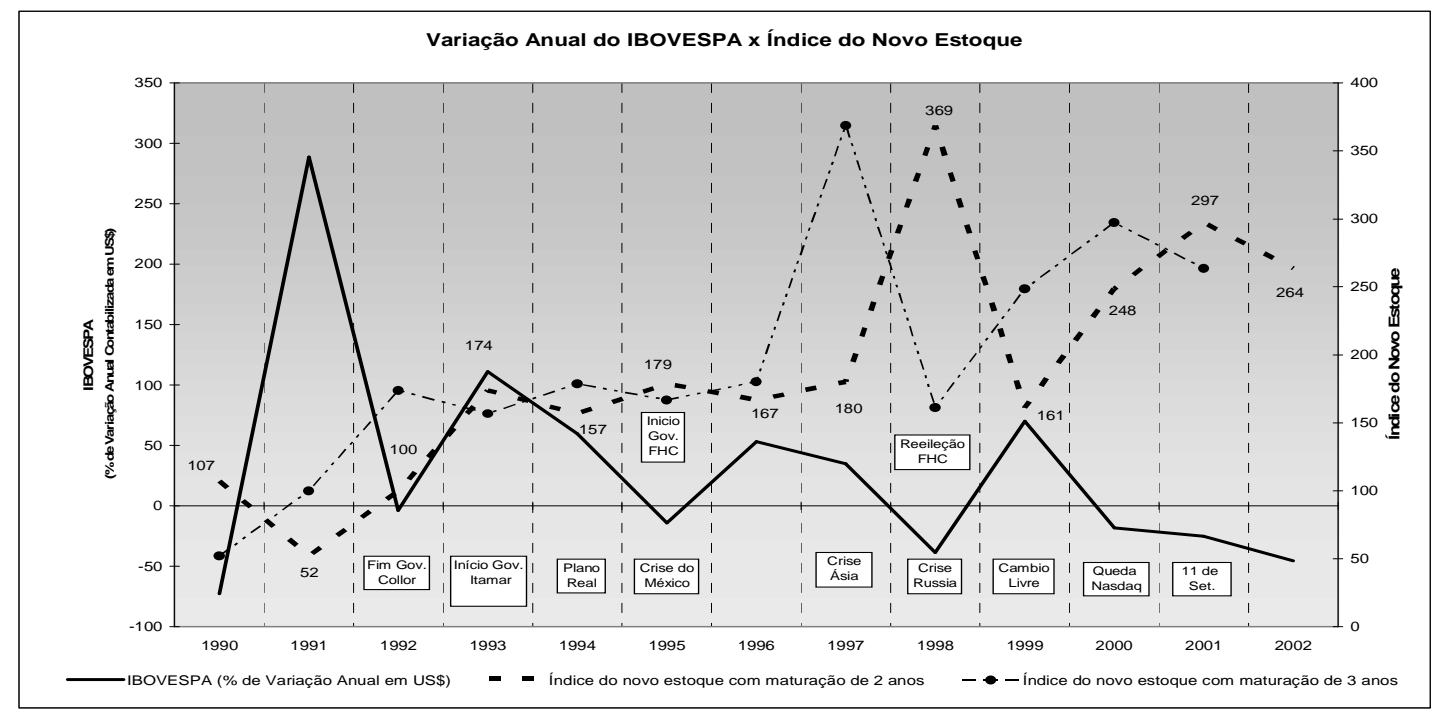

Pode-se observar pelo gráfico acima um significativo comportamento inversamente semelhante $^{36}$ entre as curvas. Vale destacar que na curva referente a dois anos de maturação há maior notoriedade de tal comportamento.

\footnotetext{
36 Para os períodos de 1994 a 2002, com dois anos de defasagem, encontramos significativos coeficientes de correlação, sendo de $-0,82$ no período e de $-0,72$ em todo o ciclo de análise. Por outro lado, a correlação encontrada para o mesmo período de análise com três anos de defasagem é equivalente a $-0,17$.
} 
Dessa forma, baseando-se em Rocha Lima e Alencar (2004), quando discorrem sobre as características estruturais que determinam que os empreendedores construam para vender - sendo a lógica dos empreendedores não diretamente associada à operação do empreendimento - e nas observações dos comportamentos das séries de novo estoque e IBOVESPA, podemos entender que as semelhanças entre as decisões de investir na Bolsa de Valores e no mercado de EEL estariam explicadas pelo caráter especulativo $^{37}$ desses investimentos.

Partindo do princípio que o período de maturação dos edifícios em análise é predominantemente de dois anos, pelo comportamento inverso das curvas encontrado no gráfico em questão, podemos perceber um movimento significativo do capital transitando entre o mercado imobiliário e o mercado de capitais.

Refletindo sobre a impressão de segurança dos investidores no mercado imobiliário que motiva tal oscilação do capital, estabelecemos o seguinte raciocínio: partindo do princípio hipotético de que não há oscilações da taxa referencial de juros da economia, se, em média, as ações do mercado local de capitais se encontram predominantemente em queda, a economia local se apresenta em crise. Este cenário, por sua vez, inibe o processo de expansão das empresas locais ocupantes de espaços de escritórios, levando a uma redução da demanda por novas áreas de escritórios (medida pela absorção). Tal fato aumenta a taxa de vacância e reduz a velocidade de ocupação dos novos empreendimentos, reduzindo as respectivas rentabilidades dos investimentos no setor. Desta forma, podemos concluir caracterizando a motivação da movimentação de capital do mercado de ações para o mercado imobiliário,

\footnotetext{
37 "Especulativo" no sentido de investir não para auferir renda com a operação, mas sim para auferir renda na diferença entre os preços de compra e venda.
} 
buscando maior segurança nos cenários de crise, como sendo, de certa forma, uma falsa percepção de segurança?

Após conduzir o raciocínio acima para a análise de Miranda (entrevista), obtive a seguinte resposta: "A construção da hipótese pode não se sustentar dependendo de: (i) em qual patamar se estaciona a taxa de juros referencial e (ii) se "ações do mercado local de capitais" significa IBOVESPA, estamos tratando de bolsa de valores, que é curto prazo essencialmente, portanto não anda em paralelo em comparação ao investimento imobiliário, o qual é de longo prazo."

Desta forma, Miranda (entrevista) concluiu informando estar de acordo com a seguinte afirmação: "Se as condições de taxa referencial de juros estiverem em baixa (inferior à remuneração obtida nos EEL) combinada com baixo crescimento anual dos setores industrial, comercial e serviços na cidade de SP e, finalmente, se a oferta disponível de escritórios estiver alta, então investir em imóveis não será hedge $e^{38}$ para a crise".

Analisando o comentário de Miranda mencionado acima, vale primeiramente transcrever um texto da obra de Vasconcellos e Garcia (2000) referente ao mercado de capitais: "Esse segmento supre as exigências de recursos de médio e de longo prazo, principalmente com vistas à realização de investimentos em capital. A geração de oferta nesse mercado é feita por instituições não bancárias, dentre as quais se destacam as bolsas de valores, por sua importância vital para a democratização do capital...".

\footnotetext{
${ }^{38}$ A palavra hedge foi aplicada por Miranda (entrevista) no sentido de um investimento que é retirado ou deslocado de uma aplicação para outra com o intuito de reduzir o patamar de risco envolvido.
} 
Ainda analisando o comentário de Miranda, vale mencionar o entendimento de Ferrari (entrevista) sobre este assunto: “... embora os valores das cotas no mercado de capitais apresentem expressiva liquidez e volatilidade, uma parcela significativa dos investidores da bolsa de valores (medida em São Paulo pelo IBOVESPA) aplica seus recursos no setor vislumbrando o resgate no médio ou longo prazo". Assim, Ferrari conclui confirmando, pela sua experiência em aconselhamento a investidores, que a oscilação de capital entre os mercados com o intuito de reduzir o patamar de risco envolvido ou buscando maiores retornos é um fato real, o qual foi comprovado pelo comportamento do respectivo gráfico da presente pesquisa.

Com relação à falsa sensação de segurança na transferência de capital do mercado de ações para o mercado imobiliário, sob um horizonte de crise econômica, Ferrari (entrevista) mencionou entender que esta situação se confirma para o caso de investidores reativos, ou seja, investidores que esperam o cenário de crise se tornar evidente para realizar a transferência do capital. Todavia, entende que tal oscilação de capital não se configura como falsa percepção de segurança quando o investidor é pró-ativo, ou seja, entendendo que o comportamento dos mercados são cíclicos, o investidor pró-ativo prevê, por indicadores econômicos de sua confiança ou através de seus consultores financeiros, um potencial cenário de crise ou queda de valor das ações no curto prazo e, neste momento, movimenta o capital do mercado de ações para o imobiliário, buscando aplicar em (i) imóveis de perfis distintos, com o intuito de mitigação de riscos, e (ii) focando em empreendimentos ainda em fase planejamento ou construção, onde o seu fluxo de retorno esperado ocorre em um cenário de longo prazo, para aumentar a probabilidade de não precisar depender da demanda (absorção) pelo imóvel durante a fase de crise do mercado. 
Levando em consideração o supramencionado, podemos inferir a seguinte conclusão: a motivação da movimentação de capital do mercado de ações para o mercado imobiliário, buscando maior segurança nos cenários de crise é uma falsa percepção de segurança para o investidor reativo, entretanto constitui-se uma percepção correta de segurança para o investidor pró-ativo.

Adicionalmente, a título complementar, vale inserir alguns comentários tecidos por Jaco (entrevista) referentes aos perfis dos investidores no ciclo em estudo, bem como suas respectivas motivações:

- Investidor nacional: usualmente são motivados a investir em imóveis por excesso de capital em suas atividades principais e, portanto, percebem uma necessidade de diversificar ou "imobilizar" parte do capital para mitigação de risco. Neste perfil de investidor, o momento e o potencial rendimento do mercado imobiliário no curto e médio prazo migra para uma importância secundária;

- Investidor estrangeiro: normalmente são impulsionados a investir em imóveis brasileiros após análise e percepção de estabilidade político-econômica e perspectivas de valorização do capital para retornos futuros;

Por último, Jaco (entrevista) mencionou que:

- durante a década de noventa, a maior parcela dos investimentos realizados sobre o mercado de escritórios de padrão corporativo da cidade de São Paulo era constituído de fundos de pensão e pessoas físicas, buscando diversificação do capital (mitigação de risco) e retornos ao longo prazo; 
- desde o fim da década de noventa até 2005, a maioria dos investimentos neste mercado era caracterizado por pessoas físicas e algumas corporações a procura de “imobilização" do capital;

- A partir de 2005, embora não esteja incluído no ciclo em estudo da presente pesquisa, Jaco afirmou que o perfil médio dos investidores já foi mais diversificado, ou seja, caracterizado tanto por pessoas físicas, empresas brasileiras como também por investidores estrangeiros, devido à percepção de uma maior estabilidade político-econômica no Brasil. 


\section{7) CONCLUSÕES}

Conforme descrito nos capítulos anteriores, é notório que determinados acontecimentos político-econômicos somados ao comportamento de índices da economia, bem como fatores provenientes da relação entre oferta e demanda dentro do mercado de escritórios são uma parcela significativa dos responsáveis pelo comportamento e aceitação pelo mercado de novos empreendimentos, contribuindo sobre seus respectivos resultados.

Pelo comportamento dos gráficos estudados, destacou-se a característica estrutural do setor de não linearidade da oferta e da demanda, como também os "choques", tanto externos quanto internos ao mercado, os quais confrontaram os exemplos de curvas teóricas apresentadas no capítulo 1.

Desta forma, conforme mencionado no capítulo 2, as variações de comportamento da demanda impactam no estado de confiança dos agentes econômicos e, consequentemente, na atratividade do setor. Portanto, estas variações se configuram em um importante determinante das decisões de investimento.

Todavia, no setor em estudo, foi verificada a existência de atraso ou período de maturação da reação da oferta em relação a variações (ou “choques”) ocorridos na demanda, ou seja, conforme comentado por Pritchett (1984) e por Sivitanides e Sivitanidou (2000), a defasagem entre a decisão e a inserção do empreendimento no mercado resulta em um fenômeno estrutural de comportamento, o qual em São Paulo e no ciclo em estudo, se configurou entre aproximadamente 2 e 3 anos. 
Isto posto, devido à metodologia de estudo adotada, a manipulação se concentrou primeiramente sob o ponto de vista da demanda, representada pelo comportamento do índice de absorção dos espaços de escritórios e, posteriormente, o estudo analisou o comportamento da oferta de espaços vagos de escritório disponíveis nas regiões em estudo da cidade de São Paulo. 


\section{1) Demanda:}

Com relação à demanda, foi perceptível o impacto dos acontecimentos políticoeconômicos sobre o estado de confiança médio dos agentes decisores das empresas ocupantes de espaço.

Posteriormente, tendo em vista que, durante o ciclo de análise, houve um período de expressiva influência do capital estrangeiro no país durante o governo do Presidente Fernando Henrique Cardoso, foram analisados e constatados os impactos do investimento direto estrangeiro no mercado imobiliário de São Paulo, os quais foram mais significativos entre 1998 e 2001, quando, os investimentos estrangeiros somente nas privatizações somaram aproximadamente 23 bilhões de dólares.

Entretanto, ao se analisar o ciclo em dois períodos e comparando a influência do investimento direto estrangeiro e do PIB sobre o índice de absorção, notamos que, no primeiro momento, entre 1993 e 1996, a semelhança de comportamento das curvas entre absorção e PIB aparenta ser maior, enquanto no segundo momento, entre 1997 e 2004, a semelhança de comportamento das curvas entre absorção e PIB aparenta ter sido consideravelmente menos significativa.

No segundo período, ainda comparando PIB e investimento direto estrangeiro, a curva de maior semelhança de comportamento encontrada com relação ao gráfico do índice de absorção de escritório foi esta última, levando-nos a inferir que o baixo crescimento do PIB e a exposição da economia brasileira a sucessivos choques externos de grande magnitude, resultaram em volatilidade alta da demanda por escritórios decorrente do ambiente de maior incerteza. Ainda nesse segundo período, 
se tomarmos os anos 1998 a 2001, notamos que a semelhança de comportamento entre as curvas de absorção e de investimento estrangeiro direto foi alta, reforçando a hipótese de que os elevados patamares de absorção estiveram relacionados especialmente às privatizações, concessões e empresas de tecnologia da informação que investiram no país.

Considerando a crescente globalização ocorrida nas últimas décadas, foi perceptível que a variação cambial do dólar frente ao real tem se tornado um fator determinante para o desenvolvimento de alguns setores da economia que dependem de exportação (ou de importação) de produtos ou de prestação de serviços para (ou de) outros países. Desta forma, analisamos o impacto da variação cambial do dólar frente ao real e da balança comercial brasileira na absorção de espaços de escritórios. Concluímos inferindo, sob um ponto de vista preliminar, que a relação de causa e efeito (tendo a taxa de exportação como causa e a absorção de espaços de escritórios na cidade de São Paulo como efeito), apresentou-se com representatividade sobre o período, com exceção dos anos entre 1998 e 2001.

É interessante perceber que o momento onde a taxa de exportação brasileira não se encontra com comportamento próximo à curva de absorção de espaços de escritórios é o de maior volatilidade desta, onde os investimentos diretos estrangeiros foram expressivos no Brasil e impactantes sobre o mercado de escritórios.

Adicionalmente, tendo em vista que a taxa de juros SELIC caracteriza o impacto do juros referencial da economia brasileira tanto na oferta (nos custos dos financiamentos e no custo de oportunidade) como na demanda (na capacidade da taxa de juros determinar em certo grau o aquecimento ou desaquecimento do 
investimento e demanda agregada), foram verificadas influências significativas da variação desta taxa no volume de absorção de espaços de escritórios na cidade de São Paulo.

Percebeu-se um certo comportamento inverso entre as variações na absorção de escritórios e a taxa de juros SELIC. Uma possível explicação para tal foi o fato da absorção de espaços de escritório acontecer após um aquecimento na economia (quando as empresas expandem e demandam por novos espaços), enquanto um aumento na taxa de juros SELIC se configurar como uma manobra políticoeconômica usual brasileira para atrair novos investimentos externos ao país após sofrer (ou prever) um potencial desaquecimento da economia local.

Por último, partindo-se da hipótese de que a oscilação da inflação brasileira gera um ambiente de incerteza para as previsões dos agentes tomadores de decisão das empresas ocupantes de espaço, obrigando-os, em diversos casos, a assumirem um maior patamar de risco ou a aplicar maiores coeficientes de segurança nas margens de lucro de suas novas unidades de negócio, comparamos o comportamento do mercado de escritórios com um índice inflacionário representativo (IGP-DI), com o intuito de verificar uma possível relação de causa e efeito. Entretanto, verificamos que, em um cenário de inflação controlada, possivelmente, as variações dos índices de inflação não são suficientes para constituírem fatores importantes na matriz de tomada de decisão das empresas ocupantes de espaço. 


\section{2) Oferta:}

A análise da oferta do novo estoque de escritórios foi parcialmente desenvolvida partindo-se do referencial teórico do capítulo 2, o qual permite explicar as oscilações da oferta pelos "choques" que impactam no estado de confiança dos agentes na economia, como também pelos fatores estruturais, relacionados ao fato de implantação e operação serem realizadas por distintos agentes, e conseqüentemente, com distintos objetivos, lógicas e expectativas.

Com o intuito de analisar as possíveis causas para o comportamento do gráfico de novo estoque de espaços de escritórios na cidade de São Paulo, inicialmente analisamos o impacto dos "choques" no estado de confiança dos agentes empreendedores do mercado de escritórios, por meio da confrontação entre as variações anuais negativas do novo estoque e os fatos ou "choques" políticoeconômicos, com defasagem de dois e três anos.

Posteriormente, analisamos o comportamento da variação anual do novo estoque em relação ao PIB, à taxa de vacância e ao IBOVESPA, para compreendermos melhor a natureza dos determinantes do investimento dos empreendedores de edifícios de escritórios na cidade de São Paulo.

Com relação ao PIB, ao analisarmos os períodos de 1996 a 2001, no gráfico com 3 anos de maturação, percebemos comportamentos próximos entre as curvas e inferimos que, devido à instabilidade política e econômica do final dos anos 80 e início da década de 90, os incorporadores e investidores, mesmo observando um notório aumento no PIB em 1993 (4,92\% acima de 1992), ainda permaneceram 
aparentemente inseguros com a hipótese de investir em edifícios de escritórios na cidade de São Paulo, mantendo o gráfico de momento da decisão do novo estoque (com maturação de 3 anos) aproximadamente constante até o ano de 1997, quando diversos investidores e incorporadores decidiram entrar em incorporações de novos edifícios de escritórios na cidade, que vieram culminar em uma entrega recorde em 2000 (7,1 vezes superior à entrega encontrada no ano de 1993).

Embora após 1997, o comportamento do PIB e do gráfico de novo estoque (com período de maturação de 3 anos) tenham apresentado comportamentos aproximadamente similares, não foi possível inferir possíveis relações de causa e efeito, uma vez que, conforme comentado anteriormente, o comportamento do novo estoque neste período esteve intimamente atrelado aos acontecimentos econômicos de 2000 e 2001.

Posteriormente, com o objetivo de perceber se os incorporadores utilizam-se do indicador "taxa de vacância" na decisão de iniciar novos empreendimentos, estudamos o comportamento do novo estoque (com defasagem de dois a três anos) em relação à taxa de vacância.

Foi possível verificar um comportamento inverso entre as curvas de taxa de vacância e de novo estoque, principalmente quando se considerou uma defasagem ou maturação de dois anos.

Dessa forma, a oferta de novo estoque de escritórios pelos empreendedores imobiliários da cidade de São Paulo esteve conforme observamos na teoria apresentada no capítulo 2, relacionada à demanda. A volatilidade acentuada da taxa de vacância, entretanto, seria justificada pela característica estrutural do setor de não 
linearidade da produção, como também aos "choques", tanto externos quanto internos.

Por último, com o objetivo de analisar a volatilidade de um investimento, entendido pela maior parte de seus investidores como seguro e estável, em relação a outro investimento reconhecido como de maior risco e volatilidade, foi verificado o comportamento da volatilidade da oferta de novo estoque de escritórios pelos empreendedores vis-a-vis o IBOVESPA.

Pode-se observar um significativo comportamento inversamente semelhante entre as curvas, quando analisado um período de maturação de 2 anos entre as curvas, o que nos leva a concluir que há um movimento significativo de capital transitando entre o mercado imobiliário e o mercado de capitais. 


\section{3) Sistematizações ou generalizações para futuras pesquisas e potenciais impactos:}

Com o intuito de estabelecer conclusões que contribuam diretamente para a elaboração de pesquisas futuras sobre este tema, utilizando os dados manipulados no capítulo 6, serão abordados raciocínios com relações de causa e efeito que possam possivelmente ser sistematizadas ou generalizadas, bem como serão descritos impactos potenciais destas.

Vale salientar que este item consiste em inferências baseadas no ciclo (período de 1994 a 2004) e no universo de edifícios em estudo e que, portanto, embora sejam úteis para pesquisas futuras, não podem ser admitidas como verdades absolutas, porém necessitam de validações posteriores em distintos ciclos e universos de estudo.

\subsection{1) Demanda}

Observando primeiramente o comportamento do PIB e dos investimentos diretos estrangeiros no ciclo em estudo, conforme mencionado anteriormente, percebemos que, entre 1993 e 1996, a semelhança de comportamento das curvas entre absorção e PIB aparenta ser maior, enquanto no segundo momento, entre 1997 e 2004, a semelhança de comportamento das curvas entre absorção e PIB aparenta ter sido menos significativa.

Por outro lado, no segundo período, a curva de maior semelhança de comportamento encontrada com relação ao gráfico de demanda foi a curva do investimento direto estrangeiro, levando-nos a inferir que o baixo crescimento do PIB e a exposição da 
economia brasileira a sucessivos choques externos de grande magnitude, resultaram em volatilidade alta da demanda por escritórios decorrente do ambiente de maior incerteza. Ainda nesse segundo período, se tomarmos os anos 1998 a 2001, notamos que a semelhança de comportamento entre as curvas de absorção e de investimento estrangeiro direto foi alta, reforçando a hipótese de que os elevados patamares de absorção estiveram relacionados especialmente às privatizações, concessões e empresas de tecnologia da informação que investiram no país.

Desta forma, na tentativa de sistematizar este fato ocorrido no ciclo em estudo, para que possa ser analisado e verificado em futuras pesquisas que abordem este assunto em outros ciclos e cidades, inferimos que, quanto menor o número de choques externos significativos na economia brasileira e quanto maior o crescimento anual do PIB, (i) menor a volatilidade da absorção de espaços de escritórios e (ii) maior a semelhança de comportamento entre o índice de absorção de espaços de escritórios e o PIB.

Figura 31 - Quadro esquemático da generalização da relação do comportamento do PIB e da demanda por espaços de escritórios.

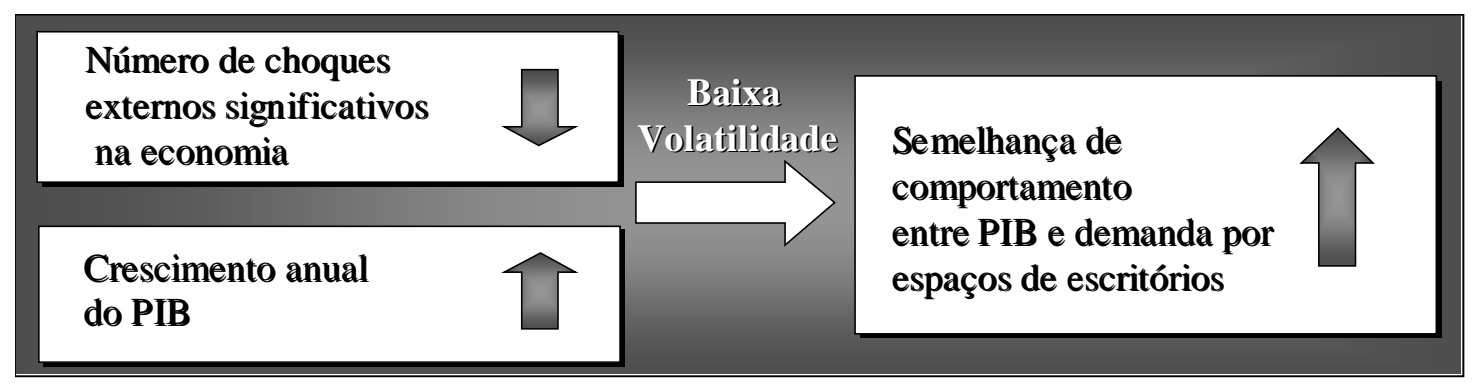

O crescimento com baixa volatilidade da demanda por escritórios constitui um cenário interessante para o mercado de real estate e para o setor da construção civil, uma vez que o mesmo estabelece um patamar de risco inferior para novos 
empreendimentos no setor, diminuindo a probabilidade de ocorrência de excesso de oferta no mercado (overbuilding ${ }^{39}$ ) e, desta forma, permitindo uma produção acelerada de novos edifícios. Vale ainda mencionar que, com a redução do risco do negócio, o crescimento do mercado com baixa volatilidade geraria a entrada de novas empresas no setor, o que motivaria um desenvolvimento do mercado com o aumento da concorrência e, por sua vez, um maior profissionalismo do setor.

Por outro lado, inferimos em paralelo que, quanto maior o volume de investimentos diretos estrangeiros no país e menor o crescimento anual do PIB, (i) maior a volatilidade da absorção de espaços de escritórios e (ii) maior a semelhança de comportamento do índice de absorção de espaços de escritórios e do investimento direto estrangeiro.

Figura 32 - Quadro esquemático da generalização da relação do comportamento dos investimentos diretos estrangeiros, do PIB e da demanda por espaços de escritórios.

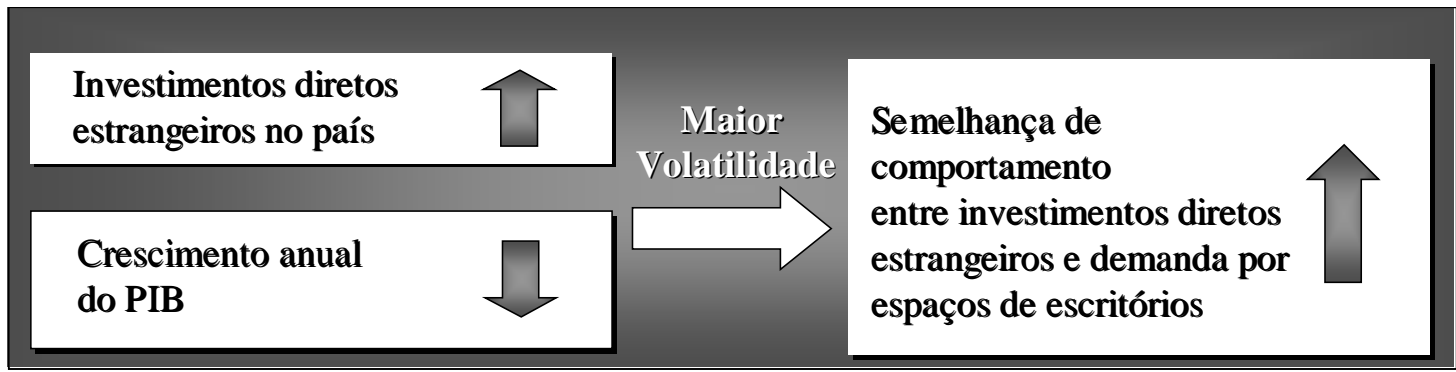

A alta volatilidade da demanda gera impacto negativo no mercado, uma vez que aumenta a probabilidade de overbuilding, gerando possivelmente problemas

\footnotetext{
${ }^{39} \mathrm{O}$ uso da palavra overbuilding justifica-se por expressar claramente o excesso de oferta de edifícios de escritórios não correspondido pela respectiva demanda.
} 
estruturais no setor, tais como, por exemplo, a inadimplência ${ }^{40}$ e, conseqüentemente, o desemprego.

Isto posto, vale também comentar que as exportações brasileiras apresentaram uma semelhança de comportamento com o índice de absorção de espaços de escritórios por todo o período, com exceção dos anos entre 1998 e 2001, quando, conforme já comentado, houve um comportamento volátil do mercado de escritórios, motivado possivelmente pelo expressivo volume de investimentos diretos estrangeiros no país.

Desta forma, caso não houvesse ocorrido o volume expressivo de investimentos diretos estrangeiros no país entre 1998 e 2001, possivelmente o comportamento da curva do índice de absorção de escritórios seria menos volátil no período e, conseqüentemente, a semelhança de comportamento com a curva das exportações brasileiras seria possivelmente mais expressiva.

Ciente do supramencionado e tendo em vista o impacto das exportações sobre o setor industrial e comercial, pode-se inferir a generalização de uma relação positiva de causa e efeito entre as exportações brasileiras e o crescimento da demanda por espaços de escritórios. Todavia vale ressaltar a fragilidade desta inferência, uma vez que, embora a semelhança de comportamento tenha sido evidente no ciclo, as exportações exercem impacto somente em uma parcela das empresas ocupantes de espaços e, portanto, possivelmente, esta semelhança de comportamento não se configure presente em outros ciclos de análise.

\footnotetext{
${ }^{40}$ Quando, em média, a expectativa de resultados financeiros não é atingida e a diferença supera as margens de segurança do planejado, o risco de crescimento da inadimplência no setor torna-se eminente.
} 
Figura 33 - Quadro esquemático da generalização da relação entre o comportamento das exportações brasileiras e da demanda por espaços de escritórios.

Volume das exportações brasileiras

\section{Frágil}

Demanda por espaços de escritórios

Tendo em vista que as exportações impactam somente em uma parcela das empresas ocupantes de espaços e, portanto, existe a possibilidade da relação acima não se sustentar, é necessária uma análise cuidadosa para considerar este indicador na fase de planejamento de novos empreendimentos. Porém, tal semelhança de comportamento é plausível para ser levada em consideração durante a definição do foco de comercialização de empreendimentos entregues ao mercado (ou em fase final de construção), uma vez que, ainda que a demanda geral por espaços de escritórios não aumente com o crescimento das exportações, sabe-se que o crescimento deste indicador econômico impactará positivamente no crescimento de determinados setores da economia, os quais possivelmente necessitarão de novos espaços de escritórios em curto ou médio prazo e, portanto, merecem a atenção dos incorporadores, dos investidores e das empresas comercializadoras de empreendimentos corporativos na fase de definição do foco de comercialização do produto.

Pelos números analisados no capítulo 6, a taxa de juros SELIC configurou-se como um dos indicadores de notória semelhança inversa de comportamento com o índice de absorção por todo o ciclo, uma vez que o crescimento do índice de absorção de espaços de escritório acontece após um aquecimento na economia (quando as 
empresas expandem e demandam por novos espaços), enquanto um aumento na taxa de juros SELIC se configura como uma manobra político-econômica usual brasileira para atrair novos investimentos externos ao país após sofrer (ou prever) um potencial desaquecimento da economia local. Desta forma, infere-se que esta relação inversa de causa e efeito pode ser generalizada.

Figura 34 - Quadro esquemático da generalização da relação entre o comportamento da taxa de juros SELIC e da demanda por espaços de escritórios.

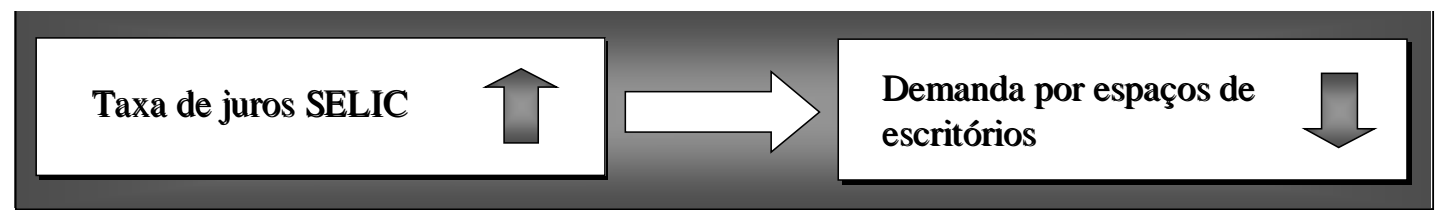

Tendo em vista que a taxa de juros referencial SELIC é um instrumento políticoeconômico, o qual dirige a percepção dos tomadores de decisão das empresas ocupantes de espaço e orienta os investimentos para os setores industrial, comercial e de serviços. Esta taxa tem potencial relação com a demanda de escritórios em médio prazo e, portanto, a percepção do incorporador e do investidor imobiliário deve incluir a análise da política monetária brasileira no momento da decisão pelo investimento, com o intuito de identificar a tendência deste indicador em um horizonte de médio prazo e, com isso, possuir um parâmetro adicional para prever a demanda no momento de entrega do edifício (final da construção).

Com relação aos impactos das oscilações inflacionárias sobre a demanda por espaços de escritórios, a teoria econômica menciona que as altas taxas de inflação provocam, entre outros efeitos, impactos sobre as expectativas de coletividade, ou seja, quanto ao futuro quadro econômico. Particularmente o setor empresarial é sensível à 
influência da inflação quando se abordam as expectativas sobre o futuro, dada a instabilidade e a imprevisibilidade de seus lucros.

Entretanto, analisando o comportamento da demanda por espaços de escritórios, sob o ponto de vista da inflação brasileira aplicada ao ciclo em estudo, o qual se configurou com cenário de inflação controlada, não foi possível identificar uma relação de causa e efeito que pudesse ser sistematizada, uma vez que, aparentemente neste cenário, as variações dos índices inflacionários não são suficientemente significativas a ponto de constituírem fatores importantes na matriz de tomada de decisão das empresas ocupantes de espaço. 


\section{$\underline{7.3 .2) \text { Oferta }}$}

Observando primeiramente o PIB brasileiro sobre o comportamento da decisão de investir em novos empreendimentos imobiliários, medida pelo gráfico de novo estoque com período de maturação de 2 a 3 anos, não foi possível estabelecer uma relação direta de causa e efeito significantemente expressiva para permitir a inferência de uma sistematização, ou seja, o impacto do PIB sobre o crescimento do novo estoque de edifícios de escritórios aparenta ser indireto e de longo prazo, uma vez que é possível inferir que o PIB precisa apresentar uma taxa de crescimento pouco volátil por anos consecutivos para influenciar significantemente as decisões dos incorporadores no longo prazo.

Ao verificar a hipótese de relação entre a taxa de vacância e a decisão por investir em novos empreendimentos imobiliários, infere-se que, em média, os investidores utilizam-se do indicador taxa de vacância no processo de decisão por novos empreendimentos.

Figura 35 - Quadro esquemático da generalização da relação entre o comportamento da taxa de vacância e da decisão por investir em novos empreendimentos de escritórios.

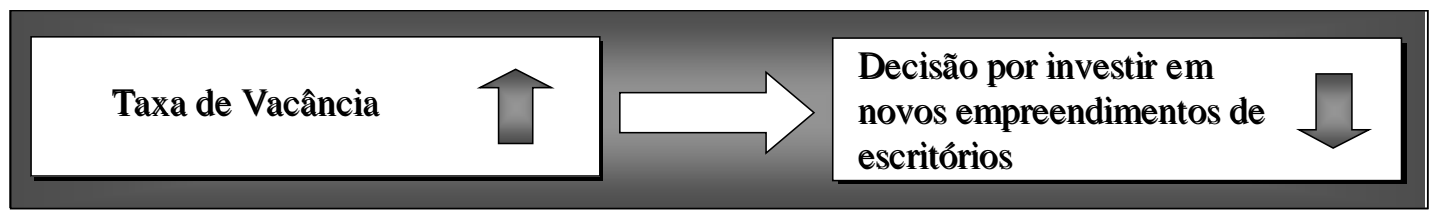

Vale comentar o risco envolvido na tomada de decisão (pelo investimento em novos empreendimentos) baseada na taxa de vacância do setor, uma vez que se trata de um 
indicador com razoável grau de volatilidade e que não mede expectativas e previsões futuras do mercado.

Em outras palavras, tendo em vista que empreendimentos de EEL demandam um período entre a decisão pelo investimento e o início do fluxo de receitas ${ }^{41}$, é aconselhável a análise de outros indicadores, tais como volume de novo estoque futuro e de previsão de oferta concorrente futura (realizando um tratamento por tamanho de laje, qualidade e localização do novo estoque).

Assim, a hipótese do comportamento médio do mercado vincular a decisão pelo investimento em EEL à análise pontual da taxa de vacância demonstra um determinado grau de amadorismo do mercado, uma vez que permite-nos concluir que uma expressiva parcela dos investimentos no setor estão sendo realizados baseados no sucesso de empreendimentos já existentes, ao invés de se basearem em estudos de comportamento do mercado futuro, o que caracteriza a prática do "inconsciente coletivo" $^{, 42}$.

Com relação ao comportamento da volatilidade da oferta de novo estoque de escritórios pelos empreendedores vis-a-vis o IBOVESPA, foi verificada a relação inversa de comportamento entre um investimento entendido pela maior parte de seus investidores como seguro e estável, em relação a outro investimento reconhecido como de maior risco e volatilidade.

\footnotetext{
${ }^{41}$ Vide Pritchett (1984) e Sivitanides e Sivitanidou (2000).

42 A expressão "inconsciente coletivo" foi mencionada por Rocha Lima em aula e abordada no capítulo 1 da presente pesquisa.
} 
Através desta verificação, constitui-se possível inferir a generalização de que existe um nítido comportamento inverso entre o IBOVESPA e a decisão do investimento em novos empreendimentos imobiliários de escritórios, devido a um movimento significativo do capital transitando entre o mercado imobiliário e o mercado de capitais.

Figura 36 - Quadro esquemático da generalização da relação entre o comportamento do IBOVESPA e da decisão por investir em novos empreendimentos de escritórios.

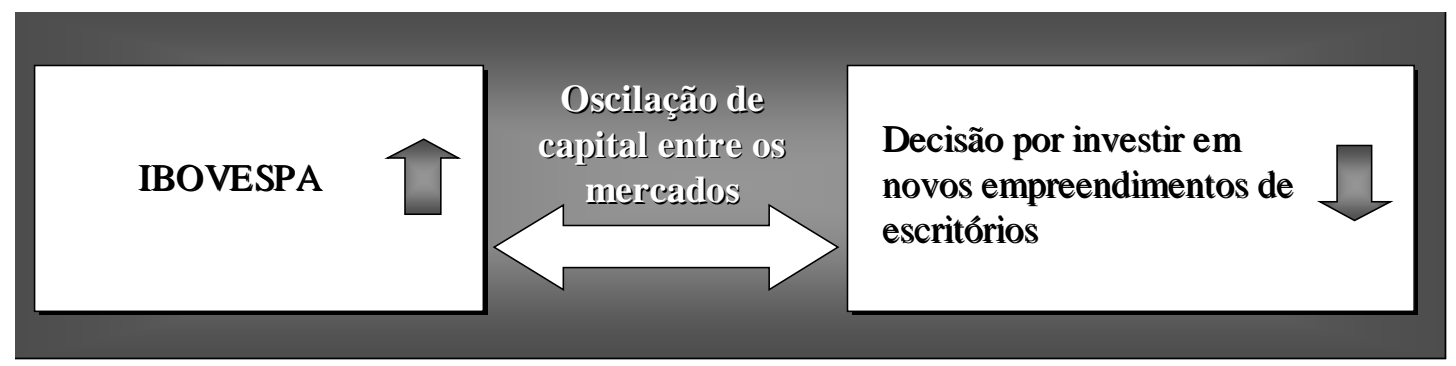

Neste momento, constitui-se plausível a realização de uma breve reflexão sobre a impressão de segurança dos investidores no mercado imobiliário que motiva tal oscilação do capital.

A motivação da movimentação de capital do mercado de ações para o mercado imobiliário, buscando maior segurança nos cenários de crise é uma falsa percepção de segurança para o investidor reativo, entretanto constitui-se uma percepção correta de segurança para o investidor pró-ativo, uma vez que o primeiro espera o cenário de crise se tornar evidente para realizar a transferência do capital, enquanto o investidor pró-ativo, entendendo que o comportamento dos mercados são cíclicos, prevê, por indicadores econômicos de sua confiança ou através de seus consultores financeiros, um potencial cenário de crise ou queda de valor das ações no curto prazo e, neste 
momento, movimenta o capital do mercado de ações para o imobiliário, buscando aplicar em (i) imóveis de perfis distintos, com o intuito de mitigação de riscos, e (ii) focando em empreendimentos ainda em fase planejamento ou construção, onde o seu fluxo de retorno esperado ocorre em um cenário de longo prazo, para aumentar a probabilidade de não precisar depender da demanda (absorção) pelo imóvel durante a fase de crise do mercado.

Por último, observando os gráficos estudados ${ }^{43}$, é possível inferir que o período médio entre a tomada de decisão pela construção de um novo empreendimento na cidade de São Paulo e a efetiva entrega do edifício ao mercado ocorre efetivamente entre 2 e 3 anos, o que se encontra em conformidade com a percepção de mercado imobiliário paulistano relatada por Sartori (entrevista) e próximo dos estudos realizados por Sivitanides e Sivitanidou (2000) sobre o mercado de empreendimentos de escritórios em regiões metropolitanas dos Estados Unidos entre 1982 e $1998^{44}$.

\section{4) Comentários finais}

Acompanhando o comportamento de gráficos de séries históricas compreendidas entre os anos de 1994 e 2004, observando os principais acontecimentos políticoeconômicos ocorridos no ciclo em estudo, contando com comentários de agentes de mercado entrevistados e com um referencial teórico, foram analisados fatores

\footnotetext{
${ }^{43}$ As análises do PIB levaram a uma conclusão do provável período de maturação ser de 3 anos, porém as análises da taxa de vacância e do IBOVESPA levaram a uma conclusão do provável período de maturação ser de 2 anos.

44 Analisando sob o ponto de vista dos investimentos realizados, os autores concluem sobre o respectivo universo de estudo que o tempo médio de conclusão de empreendimentos de escritórios se encontra entre 3,4 e 3,6 anos no período pré-recessão e entre 2,0 e 2,2 anos no período pós-recessão. Esta referência se apresenta descrita em maior detalhe no capítulo 2.
} 
influenciadores sobre o comportamento dos ciclos de ocupação em edifícios de escritórios de padrão corporativo na cidade de São Paulo.

Como um limitador da presente pesquisa, vale comentar que, embora as relações sistematizadas ou generalizadas na presente conclusão contribuam diretamente para a elaboração de pesquisas futuras sobre este tema e para a tomada de decisão sobre investimento no setor, é importante a ciência de que consistem em inferências baseadas no ciclo (período de 1994 a 2004) e no universo de edifícios em estudo e que, portanto não podem ser admitidas como verdades absolutas, ou seja, necessitam de validações posteriores em distintos ciclos e universos de análise.

Caso futuras pesquisas em outros ciclos e universos de estudo venham a comprovar como verdade absoluta (ou de expressiva probabilidade) a relação entre comportamentos de indicadores generalizados na presente dissertação, o monitoramento dos indicadores econômicos em questão constituirá uma ferramenta adicional importante (e possivelmente de impacto mensurável) para a elaboração de previsões de comportamento do mercado imobiliário. 


\section{REFERÊNCIAS BIBLIOGRÁFICAS E BIBLIOGRAFIA RELACIONADA}

ALENCAR, Claudio T, MONETTI, Eliane. Office Buildings Market in São Paulo: The Balance Between Sustainability and Investment Attractiveness. Anais em CD-ROM. XXXII Encontro Nacional de Tecnologia do Ambiente Construído (ENTAC'2004) - I Conferência Latino-Americana de Construção Sustentável (claCS’04).11p. Brasil, 18 a 21 de Julho

ALENCAR, Claudio T, O Comportamento Macroeconômico Brasileiro e os Impactos no Mercado Residencial na Cidade de São Paulo. LATIN AMERICAN REAL ESTATE SOCIETY - 10º seminário, Anais. São Paulo, Brasil, 1999, 13p.

APPRAISAL INSTITUTE. The appraisal of Real Estate. 11.ed. Chicago, 1996.

ASIAN PACIFIC OFFICE MARKET OVERVIEW - Janeiro 2002. [S1]: Colliers Jardine, jan. 2002.

BANCO CENTRAL DO BRASIL.Apresenta informações sobre Indicadores Econômicos Brasileiros. Disponível em < http://www.bcb.gov.br>. Acesso em de abril 2006.

BROWN, G. T., Real Estate Cycles Alter the Valuation Perspective, Appraisal Journal, p.539-49, 1984.

BOLLINGER, C.R.; IHLANFELDT, K.R.; BOWES, D.R. Spatial Variation in Office Rents within Atlanta. Urban Studies, v.35, n.7, p.1097-1118, 1998.

BOLSA DE VALORES DE SÃO PAULO. São Paulo. Apresenta informações sobre Índice Bovespa (IBOVESPA). Disponível em <http:www.bovespa.com.br〉. Acesso em 05 de jan. 2005.

BOMA Building Managers and Owners Association Building Classifications. Disponível em <www.boma.org> Acesso em Mar. 2007.

BUTTERS, G. R., Equilibrium Distribution of Sales and Advertising Prices, Review of Economic Studies, p.487-491, 1977.

COLLIERS INERNATIONAL. Global Office Real Estate Highlights. Boston. Dezembro 2005. (Summary Report) Diponível em <http:www.colliers.com>

COSTA NETO, P. L. de O. Estatística. 2.ed. São Paulo: Edgard Bluncher, 2002. 266p.

DIEHL, J. The Russel - NCREIF Property Indices: Institutional Real Estate Performance Benchmarks. Journal of Real Estate Literature, n.1, p. 95-103, 1993. 
DIPASQUALE, D.; WHEATON, W.C. Urban Economics and Real Estate Markets. Englewood Cliffs, NJ: Prentice Hall, 1996. 378p.

ENDO, K.S. Números Índice. $2^{\text {a }}$ ed. São Paulo, SP: Atual Editora, 1988. 73p.

Estados Unidos. Urban Land Institute. What Office Tenants Want: Office Tenant Survey Report. Washington: BOMA / ULI, 1999. 102p

EUROPEAN PROPERTY CYCLE MONITOR. Londres: Deutsche Bank Group, 2006, Anual.

FISHER, I. The Making of Index Numbers: A Study of Their Varieties, Tests and Reliability. Boston: Houghton Mifflin Co.,1922. New York: Augustos M. Kelley, 1967.

FISHER J.D.; Integrating Research on Markets for Space and Capital. Journal of the American Real Estate and Urban Economics Association, v.20, n.1, p.161180. 1992.

FISHER, J.D. GELTNER, D.; WEBB, B. Value Indices of Commercial Real Estate: A Comparison of Index Construction Methods. Journal of Real Estate Finance and Economics, v.9, 137-164, 1994.

FISHER, J.D.; WEBB, R.B. Development of na effective Rent (Lease) Index for the Chicago CBD. Journal of Urban Economics, v.39, n.1, p.161-180. 1992.

FONSECA NETO, Fernando de A. Globalização Financeira e Restrições ao Crescimento: A Economia Brasileira a partir da Década de Noventa. Brasília, 2004. 179 p. Tese (Doutorado) UNB.

FRÚGOLI JR., H. O Centro, a avenida Paulista e a avenida Luiz Carlos Berrini na perspectiva de suas associações: centralidade urbana e exclusão social. 1998. 305p. Tese (Doutorado) - Faculdade de Filosofia, Letras e Ciências Humanas, Universidade de São Paulo. São Paulo, 1998.

GATZLAFF, D.; GELTNER, David; A Transaction-Based Index of Commercial Property and its Comparison to the NCREIF Index. Journal of Real Estate Finance and Economics, v.9 , 1994

GELTNER, David; LING, D. Benchmarks \& Index Needs in te US Private Real Estate Investment Industry: Trying to Close the Gap. Technical Report. Hartford, Connecticut: Real Estate Research Institute (RERI), 2000. (PREA - PENSION REAL ESTATE ASSOCIATION).

GILBERTO, M. S., A Note on Commercial Mortgage Flows and Construction, Journal of Real Estate Research, p.485-492, 1992. 
GLASCOCK, John L. JAHANIAN S. SIRMANS C. F. An Analysis of Office Market Rents: Some Empirical Evidence. Journal of the American Real estate and Urban Economics Association. Volume 18, Issue 1, 1990

GIL, A. C., - Como elaborar projetos de pesquisa. 4.ed. São Paulo: Atlas, 2002. $175 \mathrm{p}$.

GRENADIER, S. H. Local and National Determinants of Office Vacancies. Journal of Urban Economics, v.37, n.1, p.57-71, 1995.

GRENADIER, S. H., The Persistence of Real Estate Cycles, Journal of Real Estate Finance and Economics, p.95-119, 1995.

HECKMAN, J.S. Rental Price Adjustment and Investment in the office Market. Journal of the American Real Estate and Urban Economics Association, v.13, n.1, p.32-47. 1985.

HENDESHOTT, P.H.; LIZIERI, C.M.; MATYSIAK, G. ${ }^{\text {a }}$ The Workings of the London Office Market. Journal of the American Real Estate and Urban Economics Association, v.27, n.2, p.365-387, 1999.

HOAG, J. W. Towards Indices of Real Estate Value and Return. The Journal of Finance, v.35, n.2, 1980.

HOYT, H.; WEIMER, A. M. Principles of Real Estate. $3^{\text {a }}$ ed New York, NY: Ronald Press Co., 1954. 618p.

IANNI, O. A Era do Globalismo. Brasil: Rio de Janeiro, 2001.256p;

INTERNATIONAL OFFICE MARKET REPORT - 2006 [Full Report]. Estados Unidos: Colliers International, 2006. Publicação eletrônica disponível em: <http://www.colliersmn.com>. Acesso em 03 março, 2007.

INSTITUTO DE PESQUISA ECONOMICA APLICADA (IPEA). Apresenta informações sobre Indicadores Econômicos. Disponível em <http://www.ipea.gov.br/default.jsp >. Acesso em de junho, 2006.

JARDIM DE CERQUEIRA, Lucila Lopes. As Qualidades de Localização Intrametropolitana dos Espaços de Escritórios: Evidências Teóricas e sua Evolução Recente no Mercado de São Paulo. São Paulo, 2004. 145 p. Dissertação (Mestrado) EPUSP. 2004

JONES LANG LASALLE. Perfil Imobiliário - Balanço Ano 2004. São Paulo, 2004.

KENDALL, M. G., The Early History of Index Numbers. In Studies in the History of Index Probability and Statistics. International Statistic Review, vol. 37, 1969. 
KUMMEROW, M. A System Dynamics Model of Cyclical Office Oversupply. Journal of Real Estate Research, v.18, n.1, p.233-255, 1999.

LATIN AMERICA REAL ESTATE REVIEW 2001/ 2002. [S.l.]: Colliers Interntional, 2002. Publicação eletrônica disponível em <http://www.colliersmn.com>. Acesso em 09 janeiro 2006.

LEE, H.; LEE, S.Y.; KIM, B.W. Office Rent Determinants in the Seoul Area, Korea. RAPI $27^{\text {th }}$ National Congress paper, $15 p .1999$.

MARKET SURVEY 2005. São Paulo, SP: CB RICHARD ELLIS, 2005, Anual (Estudo Técnico, 2003)

MARKET MONITOR: National real estate index. San Francisco: CB Richard Ellis, v.58,2000. Publicação eletrônica disponível em <www.realestateindex.com> Acesso em: 10 de janeiro de 2004.

MCGOUGH, T.; TSOLACOS, S. Interactions Within the Office Market Cycle in Great Britain. Journal of Real Estate Research, v.18, n.1, p.219-231, 1999

McINTOSH, Will. Real Estate Portfolio Benchmarking. Journal of Real Estate Portfolio Management, v.3, n.1, p.77-78. 1997.

MILLS, E.S. Office Rent Determinants in the Chicago Area. Journal of the American Real Estate and Urban Economics Association, v.20, n.1, p.273-287, 1992.

MONETTI, Eliane. Viabilidade Econômico-Financeira de Empreendientos. In: CONGRESSO BRASILEIRO DE ENGENHARIA DE AVALIAÇÕES E PERÍCIAS, 9, São Paulo, 1998. Anais. São Paulo. 1998. 36p.

MOUROUZI-SIVITANIDOU, Rena. Office Rent Processes: The Case of U.S. Metropolitan Markets. Real estate Economics Volume 30, Issue 2, 2002

MUELLER, Glenn R. What will the next real estate cycle look like? US, Johns Hopkins University and Legg Mason, 2002, Journal of Real Estate Portifolio Management, $17 \mathrm{p}$ Disponível em: http://www.findarticles.com/p/articles/mi_qa3759/is_200205/ai_n9036755\#continue. Acesso em:24 de setembro de 2005

MUELLER, Glenn R., Understanding Real Estate's Physical and Financial Market Cycles, Real Estate Finance, p.47-52, 1995.

MUElleR, G. R. AND S. P. LAPOSA, Submarket Cycle Analysis-A Case Study of Submarkets in Philadelphia, Seattle e Salt Lake, Publicação apresentada no American Real Estate Society (ARES), 1994. 
MUELLER, G. R. AND S. P. LAPOSA, Real Estate Market Evaluation Using Cycle Analysis, publicação apresentada no International Real Estate Society Conference, Stockholm, Sweden, 1995.

NEWELL, Graeme; WEBB, James R. Institutional Real Estate Performance Benchmarks: An International Perspective. Journal of Real Estate Literature, n.2, p. $215-224$

NOBRE, E.A.C. Expansão terciária e novas centralidades nas cidades globais: o caso da Marginal do Rio Pinheiros em São Paulo - Eduardo A. C. Nobre. In: IX ENCONTRO NACIONAL DA ANPUR (Associação Nacional de Pós Graduação e Pesquisa em Planejamento Urbano e Regional), Rio de Janeiro, 2001. Disponível em: http://www.usp.br/fau. Acesso em 30 de junho, 2005.

NOBRE, E. A. C. Reestruturação Econômica e Território: expansão econômica recente do terciário na marginal do rio Pinheiros. 2000. 309p. Tese (Doutorado) Faculdade de Arquitetura e Urbanismo, Universidade de São Paulo. São Paulo, 2000.

NORTH AMERICA OFFICE REAL ESTATE HIGHLIGHTS - 2006 [Full Report]. Estados Unidos: Colliers International, 2006. Publicação eletrônica disponível em: <http://www.colliersmn.com>. Acesso em 03 março 2007.

PERFIL IMOBILIÁRIO. São Paulo: Jones Lang LaSalle, n.3, set.2006. Publicação eletrônica trimestral disponível em: < http://www.joneslanglasalle.com.br $>$. Acesso em 3 de março de 2007.

PRITCHETT, C. P., Forecasting the Impact of Real Estate Cycles on Investments, Real Estate Review, p.85-9,1984.

PYHRR, S. A. W. L. BORN AND J. R. WEBB, Development of a Dynamic Investment Strategy Under Alternative Inflation Cycle Scenarios, Journal of Real Estate Research, p.177-93, 1990.

PYHRR, S. A., J. R. WEBB AND W. L. BORN, Analyzing Real Estate Asset Performance During Periods of Market Disequilibrium, Under Cyclical Economic Conditions, Research in Real Estate, JAI Press, Volume 3, 1990.

PYHRR, S. A., W. L. BORN, T. ROBINSON AND J. LUCAS, Valuation in a Changing Economic and Market Cycle, Appraisal Journal, 1996, 19, 102-15

PHYRR, S. A.; ROULAC, S. E.; BORN, W. L., Real Estate Cycles and Their Strategic Implications for Investors and Portifolio Managers in the Global Economy. Journal of Real Estate Research, v.18, n.1, p.7-69, 1999.

REAL ESTATE METHODOLOGY (SPECIAL REPORT). United State of America: PricewaterhouseCoopers (PWC), 1999. 
REAL ESTATE REVIEW - 2004 [Full Report]. Poland: Colliers International, 2004. Publicação eletrônica disponível em: 〈http://www.colliersmn.com>. Acesso em 03 março 2007.

REAL ESTATE TRENDS - 2004 [Full Report]. Brasil: Cushman \& Wakefield Semco, 2004. Publicação eletrônica disponível em: < http://www.cushwake.com.br〉. Acesso em 03 março 2007.

RELATÓRIO DE MERCADO IMOBILIÁRIO CORPORATIVO 2002 BRASIL Brasil: Colliers International, 2002. Publicação eletrônica disponível em: <http://www.colliersmn.com>. Acesso em 01 março 2004.

ROCHA LIMA JUNIOR, João da. Fundos de Investimento Imobiliário e Real Estate Investment Trust - João da Rocha Lima Jr. In: CONGRESSO DA URBAN LAND INSTITUTE “Real Estate América Latina”, 7p. São Paulo, 2001.

ROCHA LIMA JUNIOR, João da, Novos Produtos Financeiros e o Mercado Imobiliário - Investimentos Via Títulos de Securitização. In: Latin American Real Estate Society - Seminário LARES, dezembro de 1999. Anais em CD-ROM. São Paulo 1999.

ROCHA LIMA JUNIOR, João da, Títulos de Investimento com Lastro em Ativos O Mercado Brasileiro à Espera de um Líder. JOÃO DA ROCHA LIMA JR. 28p. Revista Álvares Penteado, v.1, n.3, FECAP - Fundação Escola de Comércio Álvares Penteado. São Paulo, 1999.

ROCHA LIMA JUNIOR, João da, Fundo de Investimento Imobiliário, com Portfolio de Base Imobiliária: Notas dobre a Depreciação do Ativo. São Paulo, EPUSP, 1997. 32p. (Boletim Técnico da Escola Politécnica da USP. Departamento de Construção Civil, BT/PCC/120).

ROCHA LIMA JUNIOR, João da, ALENCAR, Claudio T. O Mercado de Edifícios de Escritórios para Locação em São Paulo: Ciclos para Absorção do Estoque e Retomada da Atratividade do Investimento. São Paulo, EPUSP, 2004. 36 p. (Boletim Técnico da Escola Politécnica da USP. Departamento de Engenharia de Construção Civil, BT/ PCC)

ROCHA LIMA JUNIOR, João da, ALENCAR, Claudio T. O Mercado de Edifícios de Escritórios para Locação em São Paulo: O Ciclo 2000-2003 - da Euforia à Crise. São Paulo, Fundação Getúlio Vargas, 2004, Conjuntura da Construção (separata da Conjuntura Econômica) v.1, n.2, p. 10-11.

SANTOVITO, Rogério F. A dinâmica do mercado de edifícios de escritórios e a produção de indicadores de comportamento: uma simulação do índice de preços de locação em regiões de ocupação típica na cidade de São Paulo. 2004. Dissertação (Mestrado). Departamento de Engenharia de Construção Civil, Escola Politécnica, Universidade de São Paulo. São Paulo, 2004. 
SIVITANIDOU, Rena e SIVITANIDES, Petros. Does the Theory of Irreversible Investments Help Explain Movements in Office-Commercial Construction? Real estate Economics. Volume 28, Issue 4, 2000

SMITH, S. D., L. R. WOODWARD e C. T. SCHULMAN, The Effect of the Tax Reform Act of 1986 \& Overbuilt Markets on Commercial Office Property Values, Journal of Real Estate Research, p.301-320, 2000.

STEVEnSON, W. J., Estatísica Aplicada à Administração. Editora Habra, São Paulo, 1981.

TERRA, F. Planejamento Estratégico no Processo de Identificação de Regiões Geográficas para a Implantação de Edifícios Comerciais 2004. 78p. Monografia (MBA) Programa de Educação Continuada, Escola Politécnica, Universidade de São Paulo. São Paulo, 2004.

VASCONCELlOS, Marco A. S. e GARCIA, Miguel E. Fundamentos de Economia. Brasil: São Paulo, SP: Saraiva Editora, 2000. 240p;

VERONEZI, Ana B. P. Sistema De Certificação Da Qualidade De Edifícios De Escritórios No Brasil 2004. 146p. Dissertação (Mestrado). Departamento de Engenharia de Construção Civil, Escola Politécnica, Universidade de São Paulo. São Paulo, 2004.

WILLIAM C. WHEATON, RAYMOND G. TORTO. Vacancy Rates and the Future of Office Rents. Journal of the American Real estate and Urban Economics Association Volume 16, Issue 4, 1988

SASKIA, S. As Cidades na Economia Mundial. Estados Unidos: Nova Iorque, 1994.190p;

WITTEN, R. G., Riding the Real Estate Cycle, Real Estate Today, p.42-8, 1987.

WHEATON, W. C., The Cyclic Behavior of the National Office Market, Journal of the American Real Estate and Urban Economics Association, 1987, 15:4, 28199.

WHEATON, W. C. and TORTO, R. G., Vacancy Rates and the Future of Office Rents, Journal of the American Real Estate and Urban Economics Association, 1988, 16:4, 430-55.

WHEATON, W. C., R. G. Torto and J. A. Southard, Flight To or From Quality, Publicação apresentada no congresso AMERICAN REAL ESTATE SOCIETY ARES, 1995.

WURTZEBACH, Charles H.; MUELLER, Glenn R.; MACHI, Donna; The Impact of Inflation and Vacancy on Real Estate Returns. Journal of Real Estate Research. 1991. 


\section{ANEXO - Roteiros de questionamentos de entrevistas realizadas com os agentes de mercado:}

Durante a fase de manipulação dos dados da presente pesquisa, entrevistas com especialistas do mercado imobiliário de São Paulo foram elaboradas com o intuito de aprofundar as interpretações das relações de causa e efeito entre a economia e o mercado em estudo.

Vale comentar que todos os entrevistados tiveram acesso aos gráficos e dados desta pesquisa antes de responder às questões propostas.

\section{A) Questionário para Terra, representante de real estate de diversas empresas ocupantes de espaço.}

\section{Sobre a demanda:}

1) Existiu algum outro acontecimento importante que possa ter impactado no comportamento das empresas ocupantes de espaço? Caso positivo, de que forma?

2) Sob um ponto de vista político e econômico, quais são os pincipais fatores que as empresas analisam para iniciar um processo de relocalização?

3) Em media, quanto tempo uma empresa leva do momento da tomada de decisão pela relocalizaçao até a efetiva transação? Quais os processos que preenchem este período?

4) Por favor citar exemplos de empresas (clientes) com metragens e importância representativa no mecado de São Paulo que embasem a sua resposta anterior.

5) Tendo em vista o texto em referencia, por favor, comente a sua percepção sobre o impacto de cada índice econômico abaixo na absorção, embasando com experiências no mercado ou cases com clientes:

- PIB;

- Investimento direto estrangeiro; 
- Variação cambial do dólar frente ao real;

- Balança comercial brasileira;

- Taxa de Juros SELIC;

- Inflação brasileira;

Caso exista algum outro índice adicional que você acredita ter impacto sobre o índice de absorção, por favor, sinta-se à-vontade para comentar, justificando o motivo:

6) Tendo em vista o texto em referencia, por favor, comente a sua percepção sobre o impacto da queda da NASDAQ e do 11 de setembro no índice de absorção de espaços de escritórios, embasando com experiências ou cases com clientes:

\section{$\underline{\text { Sobre a Oferta: }}$}

7) Tendo em vista sua experiência de mercado com clientes corporativos, por favor, tecer comentários sobre a oferta e o novo estoque de escritórios no ciclo apresentado de 1992 a 2004.

8) Por favor, sinta-se à vontade para inserir qualquer acontecimento que possa ter impactado a entrega de novo estoque na cidade de São Paulo, justificando.

9) Tendo em vista o texto em referencia, por favor, comente a sua percepção sobre o impacto de cada índice econômico abaixo na taxa de novo estoque de escritórios, embasando com experiências no mercado ou cases com clientes:

a) Produto Interno Bruto (PIB) brasileiro;

b) Variação anual do IBOVESPA;

10) Qual a sua opinião sobre o impacto da taxa de vacância no momento de tomada de decisão dos incorporadores para a construção de um novo empreendimento?

11) Você tem raciocínios, teorias, idéias, recomendações que acredita poder me auxiliar neste trabalho? 


\section{B) Questionário para Adriano, representante comercial de proprietários com imóveis bastante representativos no mercado da cidade de São Paulo.}

\section{Sobre a demanda:}

1) Existiu algum outro acontecimento importante que possa ter impactado no comportamento das empresas ocupantes de espaço? Caso positivo, de que forma?

2) Tendo em vista o texto em referencia, por favor comente a sua percepção sobre o impacto de cada índice econômico abaixo na absorção ou na tomada de decisão das empresas ocupantes de espaço, embasando com experiências no mercado ou cases com clientes:

a) PIB;

b) Investimento direto estrangeiro;

c) Variação cambial do dólar frente ao real;

d) Balança comercial brasileira;

e) Taxa de Juros SELIC;

f) Inflação brasileira;

Caso exista algum outro índice adicional que você acredita ter impacto sobre a absorção, por favor, sinta-se à-vontade para comentar, justificando o motivo.

3) Tendo em vista o texto em referencia, por favor, comente a sua percepção sobre o impacto da queda da NASDAQ e do 11 de setembro na absorção de espaços de escritórios, embasando com experiências ou cases com clientes:

\section{$\underline{\text { Sobre a Oferta: }}$}

4) Você esta de acordo com a afirmação do texto de que o tempo que uma empresa incorporadora leva do momento da tomada de decisão pela construção de um novo empreendimento até a efetiva entrega do edifício no mercado é de 2 a 3 anos? 
5) Considerando sua experiência e aconselhamento na formatação de novos empreendimentos, quais os processos que preenchem este período? É possível citar exemplos de incorporações com este perfil que ocorreram dentro do ciclo em estudo?

6) Observando o gráfico 10 e tendo em vista sua experiência de mercado com clientes representativos do mercado imobiliário, por favor, tecer comentários sobre a oferta e o novo estoque de escritórios no ciclo apresentado de 1992 a 1994.

7) Por favor, sinta-se à vontade para comentar qualquer acontecimento que possa ter impactado a entrega de novo estoque na cidade de São Paulo, justificando.

8) Tendo em vista o texto em referencia, por favor comente a sua percepção sobre o impacto de cada índice econômico abaixo na taxa de novo estoque de escritórios, embasando com experiências no mercado ou cases com clientes:

a) Produto Interno Bruto (PIB) brasileiro;

b) Variação anual do IBOVESPA;

Na sua opinião, quais outros índices são analisados no processo de tomada de decisão pela construção ou incorporação de um novo empreendimento? Porque?

9) Qual a sua opinião sobre o impacto da taxa de vacância no momento de tomada de decisão dos incorporadores para a construção de um novo empreendimento?

10) Quais são os principais fatores que as empresas incorporadoras analisam no mercado imobiliário e na economia para iniciar um processo de construção de um novo empreendimento?

10.1) Quais as diferenças entre os motivos de um incorporador estrangeiro e um nacional?

10.2) Quais as diferenças entre os motivos de um grande proprietário pessoa jurídica e de pessoa física?

Observação: Por favor sinta-se a vontade para inserir exemplos de mercado. 
11) Tendo em vista sua experiência de mercado, você consegue identificar perfis diferentes de proprietários e incorporadores que caracterizaram fases distintas do ciclo analisado? Caso positivo, quais os motivos que os impulsionaram para o mercado imobiliário.

12) Você concorda com a afirmação abaixo extraída do texto em referência? Porque? (vide abaixo)

"Refletindo sobre a impressão de segurança dos investidores no mercado imobiliário que motiva tal oscilação do capital, estabelecemos o seguinte raciocínio: partindo do princípio hipotético de que não há oscilações da taxa referencial de juros da economia, se, em média, as ações do mercado local de capitais se encontram predominantemente em queda, a economia local se apresenta em crise. Este cenário, por sua vez, inibe o processo de expansão das empresas locais ocupantes de espaços de escritórios, levando a uma redução da demanda por novas áreas de escritórios (medida pela absorção). Tal fato aumenta a taxa de vacância e reduz a velocidade de ocupação dos novos empreendimentos, reduzindo as respectivas rentabilidades dos investimentos no setor. Desta forma, concluímos caracterizando a motivação da movimentação de capital do mercado de ações para o mercado imobiliário, buscando maior segurança nos cenários de crise, como sendo, de certa forma, uma falsa percepção de segurança."

13) Tendo em vista que momento final do ciclo foi em 2004 e que não apresenta mais risco de impactar nos negócios atuais, quais as principais estratégias de comercialização que caracterizaram cada período do ciclo e quais os seus respectivos motivos? Quais obtiveram sucesso e quais foram surpreendidas por acontecimentos inesperados do mercado?

14) Você tem raciocínios, teorias, idéias, recomendações que acredita poder me auxiliar neste trabalho? 


\section{C) Questionário para Jaco e Ferrari, respectivamente diretor e gerente de uma divisão especializada em aconselhamento a investidores imobiliários:}

\section{Sobre a demanda:}

1) Existiu algum outro acontecimento importante que possa ter impactado no comportamento das empresas ocupantes de espaço? Caso positivo, de que forma?

2) Tendo em vista o texto em referencia, por favor comente a sua percepção sobre o impacto de cada índice econômico abaixo na absorção, embasando com experiências no mercado ou cases com clientes:
a) PIB;
b) Investimento direto estrangeiro;
c) Variação cambial do dólar frente ao real;
d) Balança comercial brasileira;
e) Taxa de Juros SELIC;
f) Inflação brasileira.

Caso exista algum outro índice adicional que você acredita ter impacto sobre a absorção, por favor, sinta-se à-vontade para inserir abaixo, justificando o motivo:

3) Tendo em vista o texto em referencia, por favor, comente a sua percepção sobre o impacto da queda da NASDAQ e do 11 de setembro na absorção de espaços de escritórios, embasando com experiências ou cases com clientes:

\section{$\underline{\text { Sobre a Oferta: }}$}

4) Você esta de acordo com a afirmação do texto de que o tempo que uma empresa incorporadora leva do momento da tomada de decisão pela construção de um novo empreendimento até a efetiva entrega do edifício no mercado é de 2 a 3 anos? Quais 
os processos que preenchem este período? É possível citar exemplos de incorporações com este perfil que ocorreram dentro do ciclo em estudo?

5) Tendo em vista sua experiência de mercado com clientes representativos do mercado imobiliário, por favor, tecer comentários sobre a oferta e o novo estoque de escritórios no ciclo apresentado de 1994 a 2004.

6) Por favor, sinta-se à vontade para inserir qualquer acontecimento que possa ter impactado a entrega de novo estoque na cidade de São Paulo, justificando.

7) Tendo em vista o texto em referencia, por favor comente a sua percepção sobre o impacto de cada índice econômico abaixo na taxa de novo estoque de escritorios, embasando com experiências no mercado ou cases com clientes:

a) Produto Interno Bruto (PIB) brasileiro;

b) Variação anual do IBOVESPA;

$\mathrm{Na}$ sua opinião, quais outros índices são analisados no processo de tomada de decisão pela construção ou incorporação de um novo empreendimento? Porque?

8) Qual a sua opinião sobre o impacto da taxa de vacância no momento de tomada de decisão dos incorporadores para a construção de um novo empreendimento?

9) Quais são os principais fatores que as empresas incorporadoras analisam no mercado imobiliário e na economia para iniciar um processo de construção de um novo empreendimento?

10) Quais são os principais fatores que os investidores analisam no mercado imobiliário e na economia para aplicar recursos em um novo empreendimento? Quais as diferenças entre os motivos de um investidor estrangeiro e um nacional? Quais as diferenças entre os motivos de um grande investidor pessoa jurídica e de pessoa física?

Observação: Por favor, sinta-se a vontade para inserir exemplos de mercado. 
11) Tendo em vista sua experiência de mercado, você consegue identificar perfis diferentes de investidores que caracterizaram fases distintas do ciclo analisado? Caso positivo, quais os motivos que os impulsionaram para o mercado imobiliário.

12) Você concorda com a afirmação abaixo extraída do texto em referência? Porque?

"Refletindo sobre a impressão de segurança dos investidores no mercado imobiliário que motiva tal oscilação do capital, estabelecemos o seguinte raciocínio: partindo do princípio hipotético de que não há oscilações da taxa referencial de juros da economia, se, em média, as ações do mercado local de capitais se encontram predominantemente em queda, a economia local se apresenta em crise. Este cenário, por sua vez, inibe o processo de expansão das empresas locais ocupantes de espaços de escritórios, levando a uma redução da demanda por novas áreas de escritórios (medida pela absorção). Tal fato aumenta a taxa de vacância e reduz a velocidade de ocupação dos novos empreendimentos, reduzindo as respectivas rentabilidades dos investimentos no setor. Desta forma, concluímos caracterizando a motivação da movimentação de capital do mercado de ações para o mercado imobiliário, buscando maior segurança nos cenários de crise, como sendo, de certa forma, uma falsa percepção de segurança."

13) Você tem raciocínios, teorias, idéias, recomendações que acredita poder me auxiliar neste trabalho?

\section{D) Questionário para Mauro Miranda, coordenador do programa de investimentos imobiliários do programa de educação continuada da FGV- Eaesp:}

Sobre a demanda:

1) $\mathrm{Na}$ sua opinião, existiu algum outro acontecimento importante que possa ter impactado no comportamento das empresas ocupantes de espaço? Caso positivo, de que forma? 
2) Tendo em vista o texto em referencia, por favor comente a sua percepção sobre o impacto de cada índice econômico abaixo na absorção ou na tomada de decisão das empresas ocupantes de espaço:
a) PIB;
b) Investimento direto estrangeiro;
c) Variação cambial do dólar frente ao real;
d) Balança comercial brasileira;
e) Taxa de Juros SELIC;
f) Inflação brasileira;

Caso exista algum outro índice adicional que você acredita ter impacto sobre a absorção, por favor, sinta-se à-vontade para inserir abaixo, justificando o motivo:

3) Tendo em vista o texto em referencia, por favor, comente a sua percepção sobre o impacto da queda da NASDAQ e do 11 de setembro na absorção de espaços de escritórios:

\section{Sobre a Oferta:}

4) Você esta de acordo com a afirmação do texto de que o tempo que uma empresa incorporadora leva do momento da tomada de decisão pela construção de um novo empreendimento até a efetiva entrega do edifício no mercado é de 2 a 3 anos? Porque?

5) Tendo em vista sua experiência no mercado em investimentos imobiliários, por favor, tecer comentários sobre a oferta e o novo estoque de escritórios no ciclo apresentado de 1994 a 2004.

6) Por favor, sinta-se à vontade para inserir qualquer outro acontecimento que possa ter impactado a entrega de novo estoque na cidade de São Paulo, justificando. 
7) Tendo em vista o texto em referencia, por favor comente a sua percepção sobre o impacto de cada índice econômico abaixo na taxa de novo estoque de escritórios:

a) Produto Interno Bruto (PIB) brasileiro;

b) Variação anual do IBOVESPA;

$\mathrm{Na}$ sua opinião, quais outros índices são analisados no processo de tomada de decisão pela construção ou incorporação de um novo empreendimento? Porque?

8) Qual a sua opinião sobre o impacto da taxa de vacância no momento de tomada de decisão dos incorporadores para a construção de um novo empreendimento?

9) Na sua opinião, quais são os principais fatores que as empresas incorporadoras analisam no mercado imobiliário e na economia para iniciar um processo de construção de um novo empreendimento? E com relação aos investidores?

9.1) Quais as diferenças entre os motivos de um investidor estrangeiro e um nacional?

9.2) Quais as diferenças entre os motivos de um grande investidor pessoa jurídica e de pessoa física?

Obs: Por favor sinta-se a vontade para inserir exemplos de mercado.

10) Você consegue identificar perfis diferentes de investidores (e incorporadores) que caracterizaram fases distintas do ciclo analisado? Caso positivo, quais os motivos que os impulsionaram para o mercado imobiliário em cada fase?

11) Você concorda com a afirmação abaixo extraída do texto em referência? Porque? "Refletindo sobre a impressão de segurança dos investidores no mercado imobiliário que motiva tal oscilação do capital, estabelecemos o seguinte raciocínio: partindo do princípio hipotético de que não há oscilações da taxa referencial de juros da economia, se, em média, as ações do mercado local de capitais se encontram predominantemente em queda, a economia local se apresenta em crise. Este cenário, por sua vez, inibe o processo de expansão das empresas locais ocupantes de espaços 
de escritórios, levando a uma redução da demanda por novas áreas de escritórios (medida pela absorção). Tal fato aumenta a taxa de vacância e reduz a velocidade de ocupação dos novos empreendimentos, reduzindo as respectivas rentabilidades dos investimentos no setor. Desta forma, concluímos caracterizando a motivação da movimentação de capital do mercado de ações para o mercado imobiliário, buscando maior segurança nos cenários de crise, como sendo, de certa forma, uma falsa percepção de segurança."

12) Você tem raciocínios, teorias, idéias, recomendações que acredita poder me auxiliar neste trabalho? 